\title{
Not Applicable: Preservation and Healing in regards to the Asinabka Land through Multicultural Revealing of Hidden Layers
}

\author{
By
}

Bethany Houle

A thesis submitted to the Faculty of Graduate and Post Doctoral Affairs

in partial fulfillment of the requirements for the degree of

Masters

In

Architecture

Carleton University

Ottawa, Ontario

(C) 2018

Bethany Houle 


\section{Thesis Abstract}

The purpose of this thesis is to reveal the hidden and omitted layers of history of the Asinabka site that have been overlooked by the dominant Western culture; this singular Western viewpoint provides one dimension of realization, and one perspective to the issues surrounding the Chaudière falls and the neighboring islands. By revealing multicultural stories, a deep and enriched history of the Asinabka site emerges; by understanding the full history we can begin a discussion about the future of the Asinabka site in a way that provide an understanding of its history, meaning, and substance. The future design and healing of the land will not only address the buildings on the site, but also acknowledge the past and future implications of decisions made on the land. 


\section{Acknowledgements}

I would like to acknowledge architect Douglas Cardinal and the late William Commanda and for their 30+ years supporting the vision of the Algonquin peoples. Thank you for continuing the fight for Asinabka and not giving up no matter the odds.

Thank you to elder Albert Dumont (also known as South Wind) for his blogs and for keeping the Circle Strong. He has been standing up for the rights of Indigenous peoples and standing up for the protection of the Anishinaabe sacred site. I owe my deepest gratitude to him for travelling to Ottawa to be interviewed- much of his knowledge guided the direction of this thesis and illuminated a new perspective on the issues at Asinabka. His interview is an essential contribution and firsthand account of Asinabka and warrants great respect.

Thank you to Eric Smith and Nathan Jensen, my predecessors before me, who made enormous contributions to unveiling the stories of the land through their theses. Their writings on Asinabka show they kept an open mind in their search for truth.

Thank you to Professor Greg Andonian, Doctor Allan Ryan, and Martha Attridge-Bufton who were a wealth of information and helped guide me to the proper resources. Thank you for showing interest in my pursuit of unveiling the different perspectives and stories of the islands and the Falls as well as providing guidance throughout the process.

A special thanks to my thesis director, Professor Federica Goffi, whose meticulous comments and feedback were invaluable in the completion of this thesis. Thank you for your constructive comment, warm encouragement, and support.

And a very special thanks to my loving husband Jeremy Houle and my parents Elaine and Morris Gould for their steadfast strength and belief in me through my undergraduate and graduate studies. I couldn't have accomplished what I did without your prayers, wisdom, and guidance.

1 Peter 1:3-12 


\section{Table of Contents}

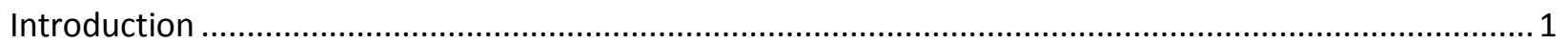

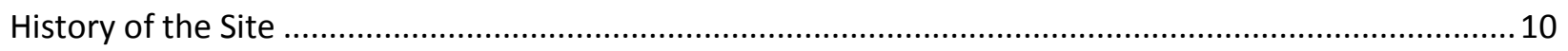

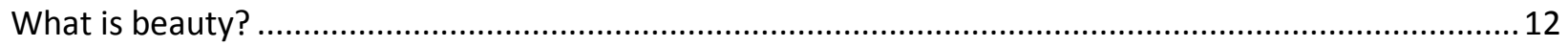

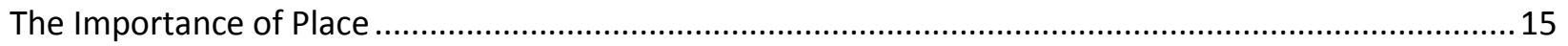

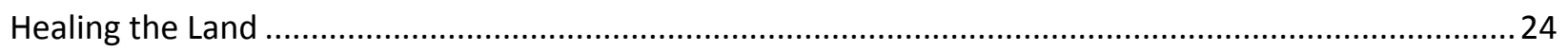

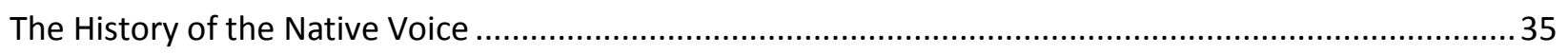

Oka Crisis Movement; Kanehsatake: 270 Years of Resistance .......................................................... 35

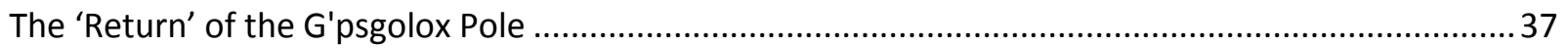

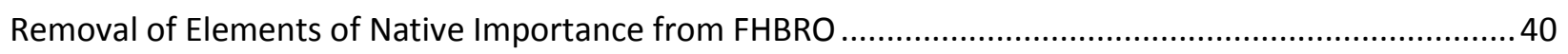

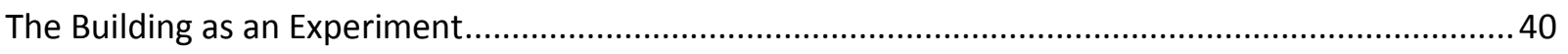

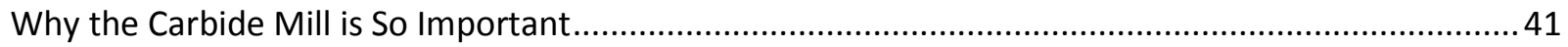

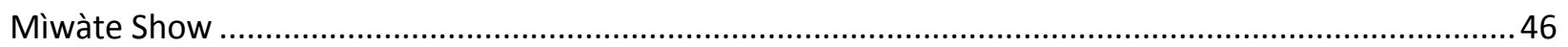

United Nations Declaration on the Rights of Indigenous Peoples........................................................50

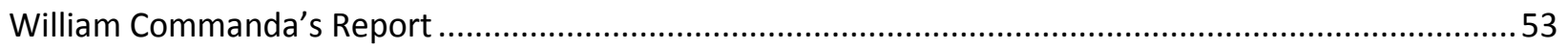

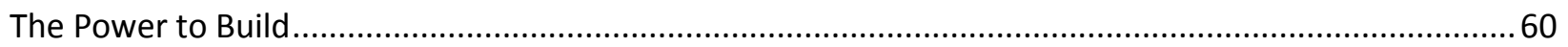

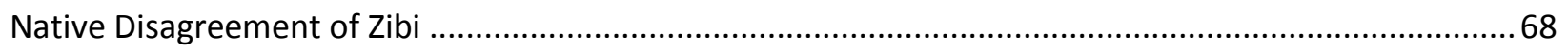

Conclusion: Communicate a Message through Actions ................................................................... 72

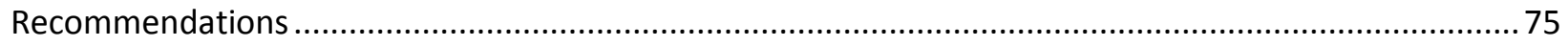

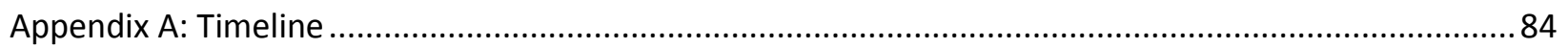

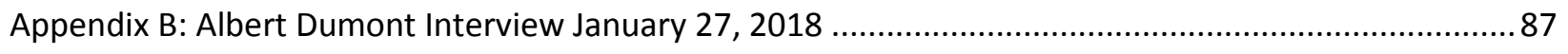

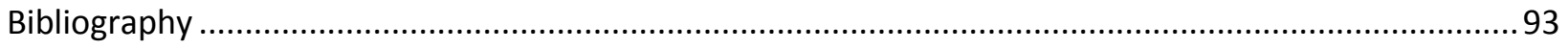




\section{List of Illustrations}

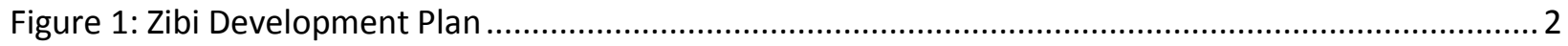

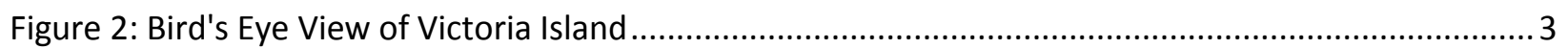

Figure 3: Royal Proclamation of 1763 by King George III Stating Unceded Land as Aboriginal Owned ....... 5

Figure 4: "Darth Vader" by Cedric Delsaux's "Dark Lens" series (2009), Diesel Art Gallery, Tokyo ............. 8

Figure 5: "X-Wing \& Vader" by Cedric Delsaux's "Dark Lens" series (2009), Diesel Art Gallery, Tokyo ....... 9

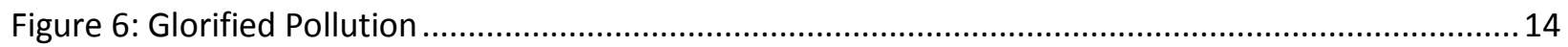

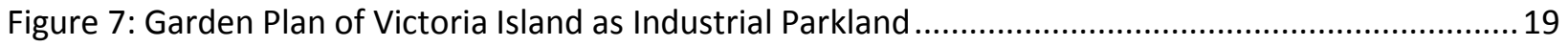

Figure 8: Industrial Parkland Sketches before Portage Bridge ............................................................ 20

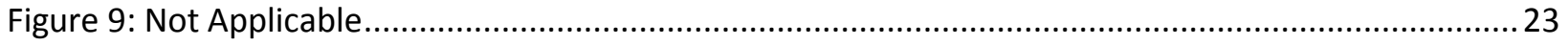

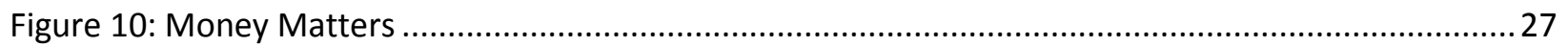

Figure 11: 2017 Flooding of the Ottawa River (taken by Lauren Stoymenoff) .........................................30

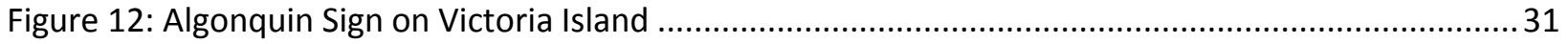

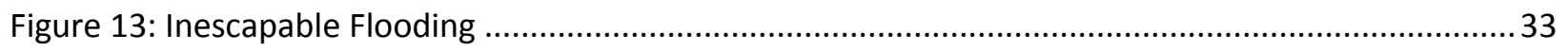

Figure 14: Artistic Cover-up of Flooding (Use of Jim Oskineegish Painting) .............................................34

Figure 15: Carbide Mill Photo from the official FHBRO ..................................................................... 44

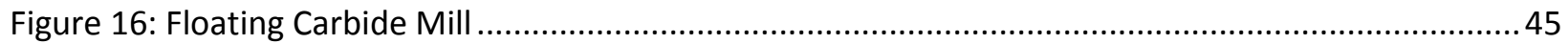

Figure 17: Chaudière Islands as Gathering Place for Indigenous and Non-Indigenous Peoples ............... 49

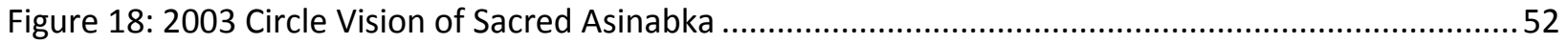

Figure 19: Proposed Program for the Healing Center and the Peace Building Center ..............................54

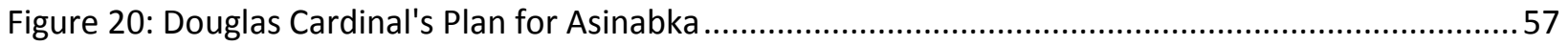

Figure 21: Concept Plan for Asinabka; Incorporation of Carbide Mill .......................................................58

Figure 22: Renderings of Douglas Cardinal's Asinabka Peace Building...................................................59

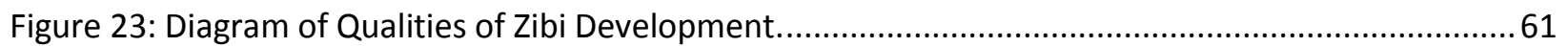

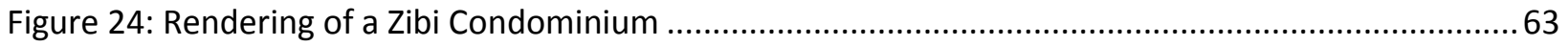

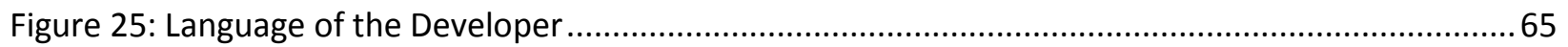

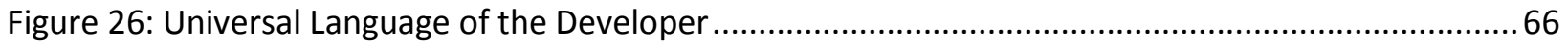

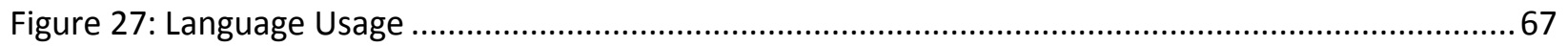

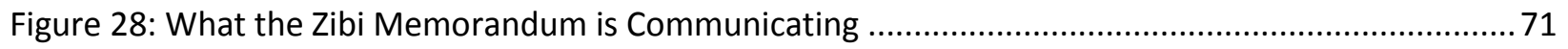

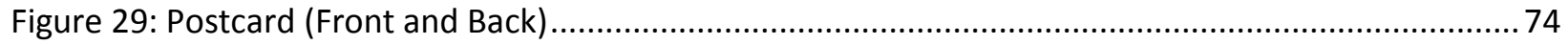

Figure 30: Carbide Mill Relocated to the Byward Market .................................................................... 78

Figure 31:Carbide Mill Relocated to Gatineau Park............................................................................... 79

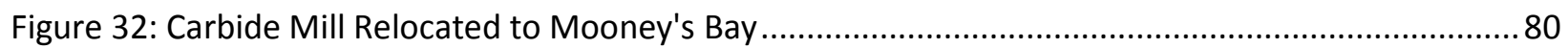

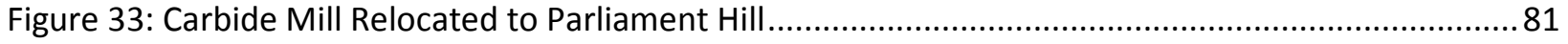

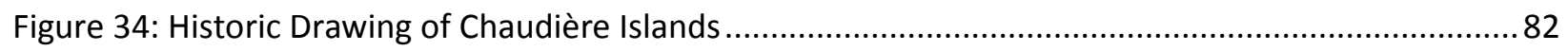

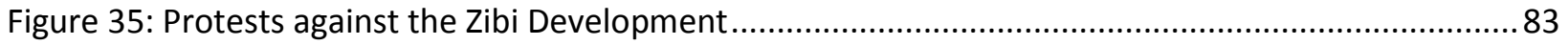




\section{Note from the Author}

As a person with unclear ancestral heritage who is living in a post-colonial society, my viewpoint is different from a native persons' who has grown up in that culture. As someone who has only been exposed to indigenous cultural studies for merely the duration of my university experience, I cannot properly express thousands of years of knowledge and understanding that come from the native peoples. I will do my best to present the argument of both the non-native peoples and native peoples equally and to the best of my ability. In respecting these cultures, I have sourced my information in a way that will allow for others with a desire to learn more about the issues presented to be able to trace the steps I have taken in this process of revealing the layers of a multi-cultural history. In my dictation, I have made it clear which are facts and quotes from the elders and which are my personal interpretations of the meaning behind the words used by both parties. 


\section{Word Usage}

In this thesis I will be using words that may not be politically correct, such as the word "Indian". The use of the word 'Indian' will be used in reference to the way the dominant culture viewed the indigenous people in the early 1800 'st. In other words, the terminology is meant to display the viewpoint of the speaker within the context of the era in which they are speaking. The wording does not reflect any personal inclinations, racism on behalf of the thesis author, nor is it meant as an act of disrespect towards anyone who is reading this document.

Other words, such as 'white', 'settlers', or 'Euro-American' are some of the terms that are used to reference non-native peoples of the dominant Canadian cultures in the 1900's; this word variety is to prevent the text from seeming monotonous in its word usage and may include peoples of other cultural backgrounds besides the Europeans.

For the sake of this thesis, I will use the word 'preservation' for Western civilization heritage tactics and I will use the word 'healing' for the indigenous ways of relating to the conservation of the land. I wish to make a specific distinction that I am not referring to the indigenous people as in need of healing, but the healing of the lands that have been polluted by leaseholders who had disregard for the land of which they were temporary caretakers. 


\section{Terminology}

\section{Indigenous (Algonquin) Terminology to English Language}

Akikodijwan: sacred site; includes Chaudière Falls and the islands downstream (Albert, Chaudière, and Victoria)

Anishinaabe: People from whence lowered from the stars

Asinabka: Place of Glare Rocks

Kitchissippi: Ottawa River

Mìwàte: dazzled by a light or fire

Pikwàkanagàn: Algonquin tribe located $1 \frac{1}{2}$ hours west of Ottawa and the only tribe asked about developments to the Chaudière sites in terms of Zibi and the Hydro Dam redevelopments.

Zibi: River

\section{Western Terminology}

Aesthetic Activism: reignited discourse on aesthetics is prompting new insights into our relationships with not only objects, spaces, environments, and ecologies, but also with each other and political structures in which we are all enmeshed ${ }^{1}$

Brownfield: a real property, the expansion, redevelopment, or reuse or which may be complicated by the presence or potential presence of a hazardous substance, pollutant, or contaminant.

Colonialism: is a complex and multifaceted process of oppression through manifold economic, ideological, and cultural processes of subjugation ${ }^{2}$;

Constituency: a body of voters in a specified area who elect a representative to a legislative body.

Healing:

1. to make healthy, whole, or sound; restore to health; free from ailment; to mend. 2. To bring to an end or conclusion, as conflicts between people or groups, usually with the strong implication of restoring former amity; settle; reconcile:

Preservation: the act of keeping something as it is, esp. in order to prevent it from decaying or to protect it from being damaged or destroyed ${ }^{3}$

${ }^{1}$ (WA Contents 2016)

2 Definition taken from page 9 Eric Smith's Thesis (Smith 2011)

${ }^{3}$ Cambridge Dictionary 


\section{List of Abbreviations:}

AFN: The Assembly of First Nations

ATK: Aboriginal Traditional Knowledge; written section in ESR

Chaudière Water Power Inc.: Three principle parties make up a corporate entity which share responsibility for managing the dam, maintaining and setting water levels (1. Hydro Ottawa Holding Inc. $(17 / 60=28.33 \%$ );

2. Hydro-Quebec $(20 / 60=33.33 \%)$; 3. Domtar Inc. $(23 / 60=38.33 \%))$

ESR: Environmental Screening Report

FHBRO: Federal Heritage Building Review Office

FHBR: Federal Heritage Building Report

Genivar: Engineering Firm hired by Domtar to prepare an Environmental Screening Report (ESR)

IEA: Individual Environmental Assessment

MOE: Ministry of the Environment

NAGPRA: Native American Graves Protection and Repatriation Act; allows native people to make decisions on how they would like their artifacts treated. Federal grant money is dedicated to repatriating artifacts, which can be human remains, sacred objects, or personal possessions. ${ }^{4}$

PWGSC: Department of Public Works and Government Services Canada

\footnotetext{
${ }^{4}$ (Sequeira 2016)
} 


\section{Introduction}

The indigenous people have always treated the "Mother Earth"- the land and environment- with respect and created a personification of the land to better understand their connection with her sustaining nature. This connection with the land allows for a more personal and in depth understanding of humans' impact on their surroundings.

The picturesque islands around the Chaudière Falls (called 'Akikodjiwan Falls' by the native peoples, visible in Figure 2: Bird's Eye View of Victoria Island) has been rezoned and offered to a private developer for the densification and urbanization of the site. This development, coined Zibi (meaning 'falls' in Anishinaabe) by the developer Windmill, plans to rehabilitate the Federal Heritage buildings from the $19^{\text {th }}$ century industrial age of Canada on the Chaudière Island site [see Figure 1: Zibi Development plan]. The buildings are planned to be renovated to become sustainable, good for the environment, economically enriching for the surrounding communities, and to offer a fresh new hipster, up-and-coming place between Ottawa and Quebec. However, while this development is seen to have many positive aspects to the average Canadian citizen, the majority of the native peoples -especially the Anishinabeg Nation who own the land- are in direct protest against this initiative. [Bold and italic emphasis added].

"Zibi, using the Algonquin word for River, is a Red-washed Commercial Exploitation, which further insults, disrespects and abuses that which is Sacred to us."

-Architect Douglas Cardinal ${ }^{5}$

${ }^{5}$ (Cardinal 2016) 


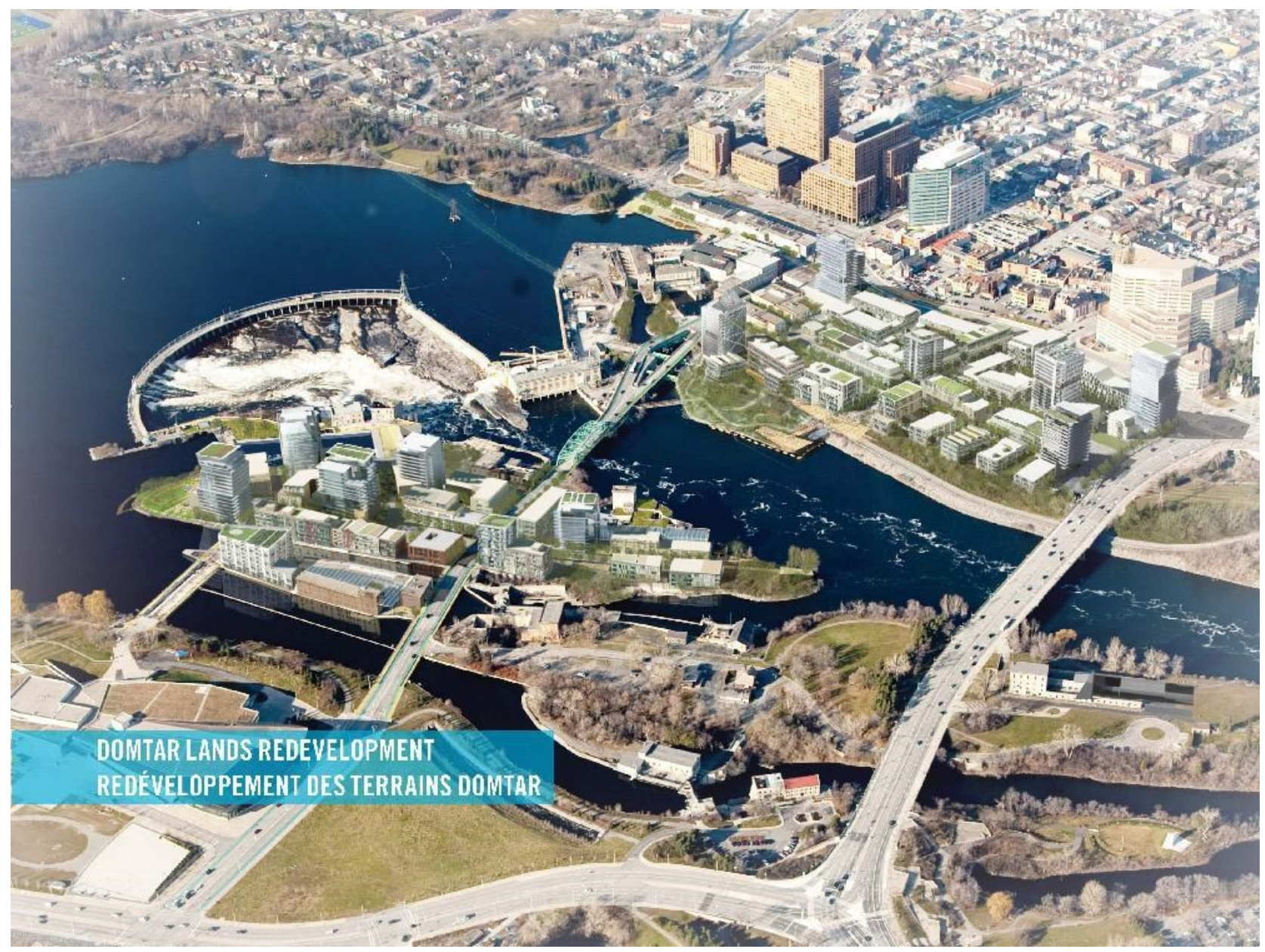

Figure 1: Zibi Development Plan ${ }^{6}$

${ }^{6}$ (Windmill 2015) 


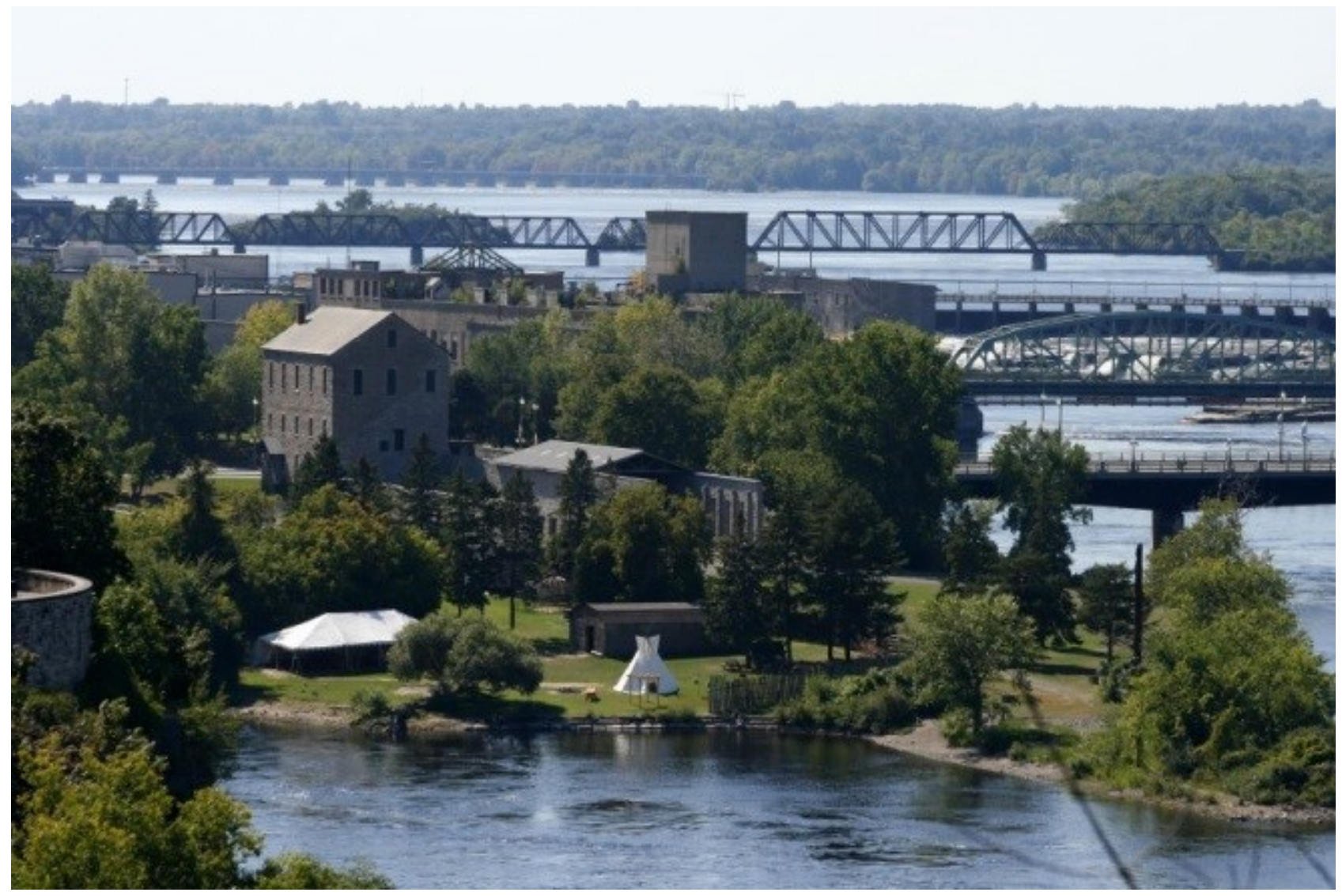

Figure 2: Bird's Eye View of Victoria Island 
The Anishinaabe people, under the Royal Proclamation of 1763 [see Figure 3], are the true holders of the land as Victoria, Chaudière, and the surrounding islands (as well as most of Ottawa) have never been sold, traded in a treaty, or surrendered ${ }^{7}$. The Royal Proclamation of 1763, also known as "Indian Magna Carta," or an "Indian Bill of Rights, signed by King George III states explicitly:

And whereas it is just and reasonable, and essential to our Interest, and the Security of our Colonies, that the several Nations or Tribes of Indians with whom We are connected, and who live under our Protection, should not be molested or disturbed in the Possession of such Parts of Our Dominions and Territories as, not having been ceded to or purchased by Us, are reserved to them, or any of them, as their Hunting Grounds. ${ }^{8}$

Although this proclamation was in service mainly to the British government as a means of retaining land from the French and the Thirteen Colonies (the United States closest to the east coast) who wanted to expand westward. . This proclamation was meant to prevent the expansion of the settler movement westward and to appease the Native Americans who had sided against him in the Seven Years' War. While this did nothing to prevent the pioneers from moving westward (even George Washington ignored this proclamation), it did spark the beginnings of the American Revolution.

However, there has never been any proclamation, or law that has counteracted the proclamation. Therefore, any lands that have not been surrendered, that are unceded, or have been given up in a treaty are still considered to be under the care and protection of the Indigenous people to that land. In the case of Ottawa and Asinabka, this means that the Algonquin people of the Anishinabeg nation are the protectors and caretakers of this land as well as over $36,000 \mathrm{~km}^{2}$ which includes the NCC Greenbelt as well as the Parliament buildings.

\footnotetext{
${ }^{7}$ (Historica Canada 2015)

${ }^{8}$ (Historica Canada 2015)
} 


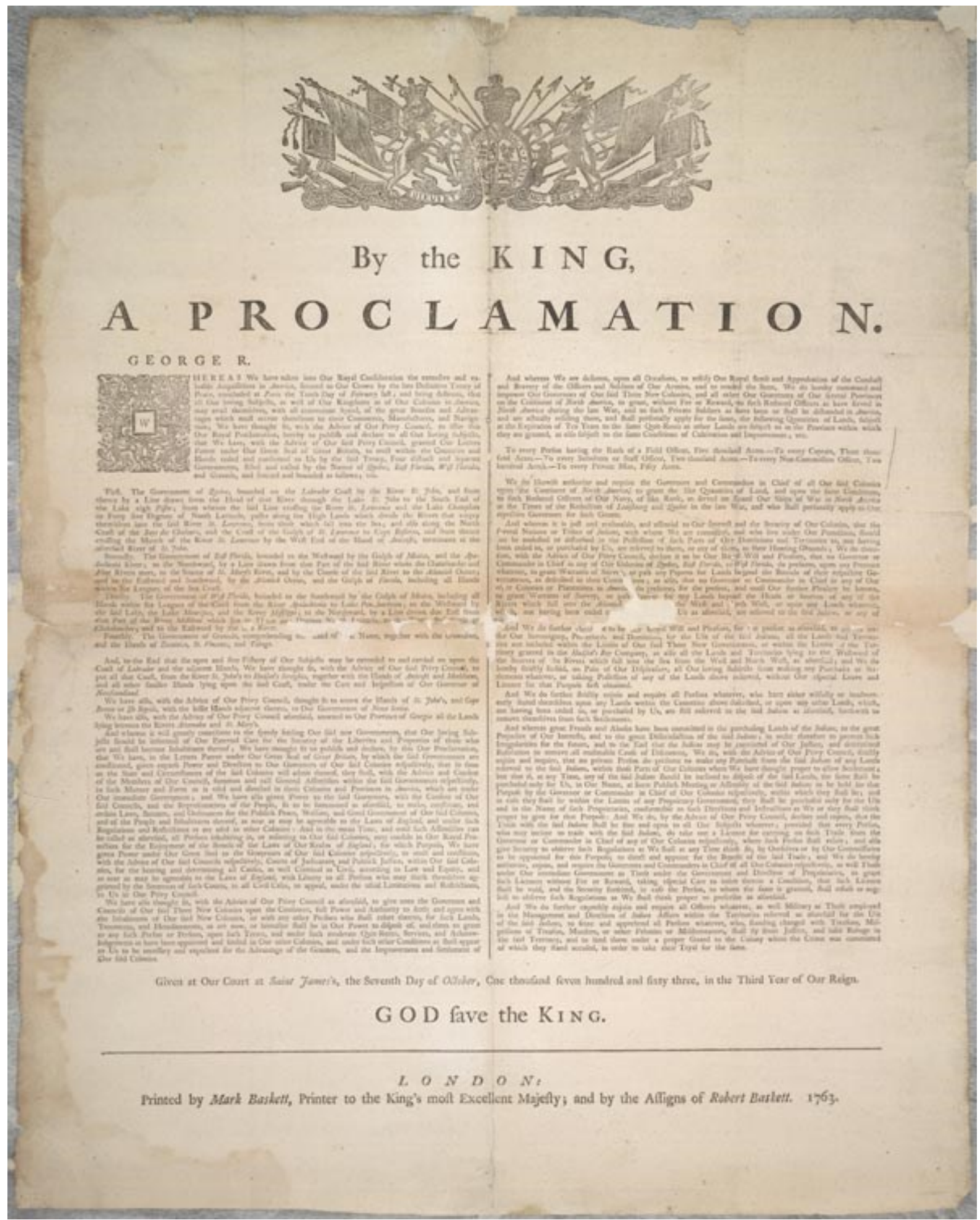

Figure 3: Royal Proclamation of 1763 by King George III Stating Unceded Land as Aboriginal Owned 
This unceded land is still under the protection and stewardship of the Anishinaabe peoples. While the land can be - and has been- leased, any decisions made by the federal government about the land must first be approved by the Anishinaabe people. Unfortunately, there is a loophole that stipulates if there is any private development, there is no need to receive approval before construction. Therefore the native people have been removed from the conversation about the future developments on their own land $^{9}$.

This thesis will argue how the differences in culture and beliefs have created this divide between these two people and how we can strive to bridge the growing animosity that has its beginnings during the first contact. Also, this thesis delves into why the native people are opposed to this development and how buildings and construction is not always the answer to $21^{\text {st }}$ century problems.

The process of revealing both concealed and hidden layers of the stories and histories on this land will be done through aesthetic activism with the strategic use of images and texts to portray a message ${ }^{10}$. Working through a visual construct of images I will reveal the perspectives of multiple cultures and how when presented closely together they begin to create a dialogue. In this way, a platform of truth is created to unveil the perspective of the minority culture alongside the dominant culture; to generate an unbiased illumination of facts that can be shocking to the general public and produce a powerful message $\mathrm{e}^{11}$. An example of this use of portraying messages through visuals can be found in the surrealist work of Cedric Delsaux in his "Dark Lens" series. Delsaux uses hyperrealism to disturb the public's sense of reality by inserting a pop culture symbol into real world settings to act as a weapon to strike at the elitism of the art world ${ }^{12}$. Delsaux's work resembles the Star Wars quote from Obi Wan Kenobi in

\footnotetext{
${ }^{9}$ (Windmill 2015)

${ }^{10}$ (Yale University 2016)

${ }^{11}$ (WA Contents 2016)

${ }^{12}$ (The Japan Times 2016)
} 
Episode VI when he says "many of the truths we cling to depend greatly on our own point of view" ${ }^{13}$. Aesthetic activism reveals these new perspectives on everyday reality and social systems that the population as a whole has been taught to accept.

${ }^{13}$ (The Japan Times 2016) 


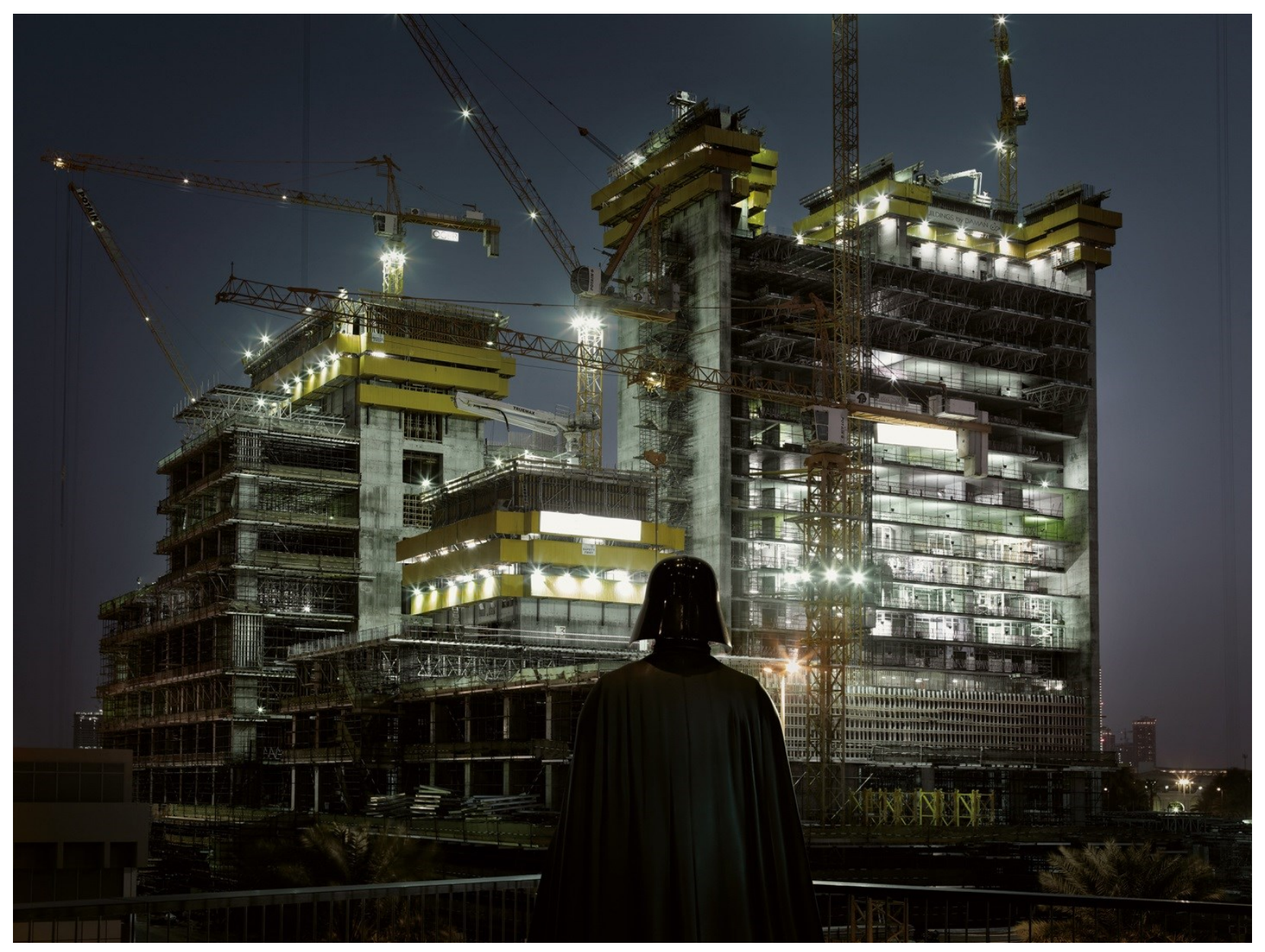

Figure 4: “Darth Vader” by Cedric Delsaux's “Dark Lens" series (2009), Diesel Art Gallery, Tokyo 


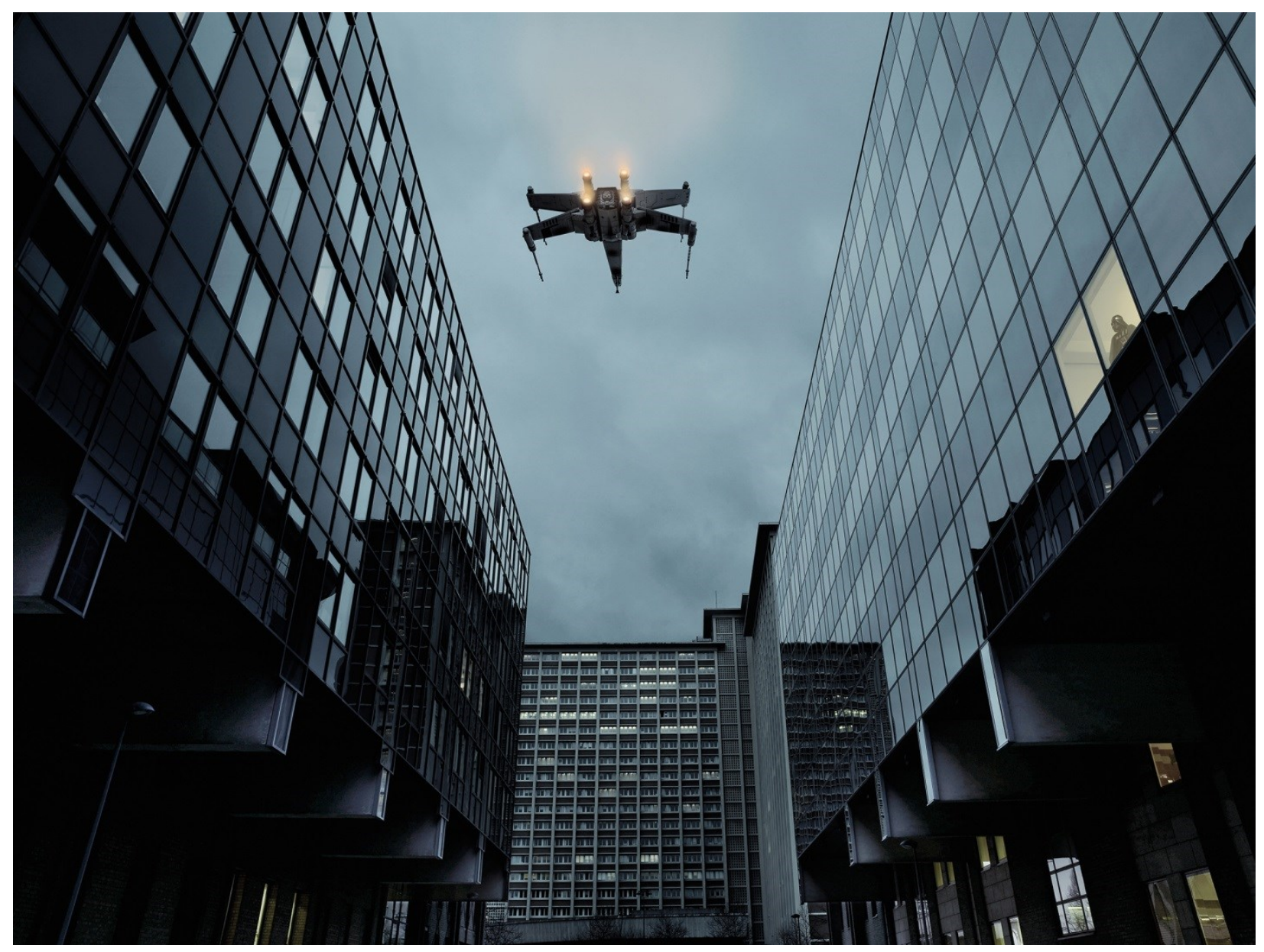

Figure 5: "X-Wing \& Vader" by Cedric Delsaux's “Dark Lens" series (2009), Diesel Art Gallery, Tokyo 


\section{History of the Site}

Asinabka, also known as Chaudière Falls or Cauldron Falls, reflects ancient indigenous knowledge of earth transformation and wisdom through its name, artifacts, and even native mythology. The falls' geological history reveals layers of ancient ocean floor from 450 million years ago brought down by the glaciers $^{14}$. The circular rapids are second only to Niagara Falls in Canada and reflect a natural medicine wheel, with the Ottawa River running west to east and the Gatineau and Rideau River running from south to north.

There are samples of ancient life organisms (invertebrates, spores, and marine algae) embedded in rock that date back to the second most ancient geological historic era called the Algonkian era (between 3.8 billion years ago and 620 million years ago). There are two locations of these glacial remnant lakes existing in the Ottawa River Watershed that show the earliest record of the precursors to life.

The indigenous people were the first inhabitants to the land that we now call Canada and the United States. Their ceremonies are land and water based. Their ways to be in contact with the spirit world and to have their prayers heard and answered is through these traditional ceremonies. Native tribes expanding through Canada and the United States are known to have travelled across the country to meet and host ceremonies at Asinabka. Their connection to place, especially the Falls, is seen through journals dating back to 1613 with the first written accounts of the Anishinaabe ceremonial practices at Asinabka. Samuel de Champlain (1574-1635), a French explorer, records where the ceremonies take place. In his own words he stated,

At one place the water falls with such violence upon a rock that, in the course of time, there has been hollowed out in it a wide and deep basin, so that the water flows round and round there and makes, in the middle, great whirlpools. Hence, the savages call it Asticou, which means

\footnotetext{
${ }^{14}$ (Circle of All Nations 2014)
} 
Kettle. This waterfall makes such a noise in this basin that it can be heard more than two

leagues off. The savages who pass by it have a ceremony which we shall describe in its place.

(Champlain 1911, v2: 12) ${ }^{15}$

Champlain's report goes on to explain his experience of the tobacco ceremony. He references that the Anishinaabe ceremony has been in practice for a long time and validates the native's claim to the importance of the Chaudière Falls site as a sacred place for over 400 years before the settlers arrived in Canada.

Continuing our course, we arrived at the Chaudière Falls, where the savages had the accustomed ceremony, which is as follows: after having carried their canoes below the falls, they get together in one place, where one of them, with a wooden plate, takes up a collection, and each one of them puts into this plate a piece of tobacco. The collection made, the plate is put into the middle of the band, and all dance around it, singing in their fashion; then one of the chiefs makes a speech, showing that for a long time they have been accustomed to make this offering.... That done, the speaker takes the plate and goes and throws the tobacco into the middle of the cauldron and they raise a great cry all together. (Champlain 1911, v2: 38-39) ${ }^{16}$ When settlers first came to this location along the Ottawa River -also known as "Kitchissippi" in Anishinaabe- they could sense the centrality, the power, and the importance of this site as a place of gathering. While the Algonquin people would not have used the islands directly adjacent to the Chaudière Falls (as that location was holy and would not have been a place of trade), they would have used the surrounding areas as places to conduct trade, to tell stories, to gather, and to reinforce

\footnotetext{
${ }^{15}$ (Pomeroy Otis 2013)

${ }^{16}$ (Pomeroy Otis 2013)
} 
intertribal bonds between the different bands. ${ }^{17}$ There is archaeological evidence that this location was a prime place where artifacts were found from different native groups. ${ }^{18}$

During the $17^{\text {th }}$ and $18^{\text {th }}$ century, the coming of first the French explorers, fur traders, and missionaries led to the death of thousands of native people due to the transference of diseases such as smallpox, tuberculosis, and typhoid fever, not to mention the loss of life due to the wars waged against the Iroquois and Mohawk peoples during the heights of the fur trade ${ }^{19}$. But the most devastating effects from first contact were the prejudices and stereotypes inherent in the perspectives of the explorers from the misunderstanding of the native people; this would later lead to massacres of the native people, the attempted assimilation of the native people through residential schools, the 60 's scoop, and the government's attempts to remove the native culture from Canada. While these explorers, Champlain in particular, created maps of the land and the sea for Henry IV, they also provided the first perspective of the native peoples overseas and cultivated the beginnings of prejudice against them. ${ }^{20}$

\section{What is beauty?}

Every Culture has a different understanding of what is beautiful. In Western civilization, the concept of beauty has to do with architecture, proportions, order, and the taming of nature ${ }^{21}$. In North American Indigenous perspectives, beauty is seen in the untamed nature and the power and natural order of the universe, as seen by their respect and ceremony at the Falls. In the following figure [Figure 6], we see the constructed reality placed in juxtaposition to the actual reality of the Industrial site on Victoria Island. In the first picture, we see a painting by amateur artist Henri Fabien (painting ca. 1914) which makes the site look like it moderates and tames nature while the industrial smoke stacks look like whimsical cloud making machines. This distancing of the artists from the actual site makes it look like a

${ }^{17}$ (Dumont 2018)

${ }^{18}$ (Circle of All Nations 2014)

19 (Smith 2011)

20 Page 74 in (Walter Phillips Gallery Editions 2005)

${ }^{21}$ Works like Da Vinci, Vitruvius, and other philosophers and architects with canonical views of the civilized world 
pleasant place to visit and the pastels make the site look clean, orderly, and peaceful. However, the reality is revealed on the site with the rusting of the storage tanks and the desolate landscape. The site looks cramped and toxic and cuts the views toward parliament hill. The railings and bars attached to the structures look constricting and controlling and would not be a nice place to visit, bring the kids, or have a picnic. 

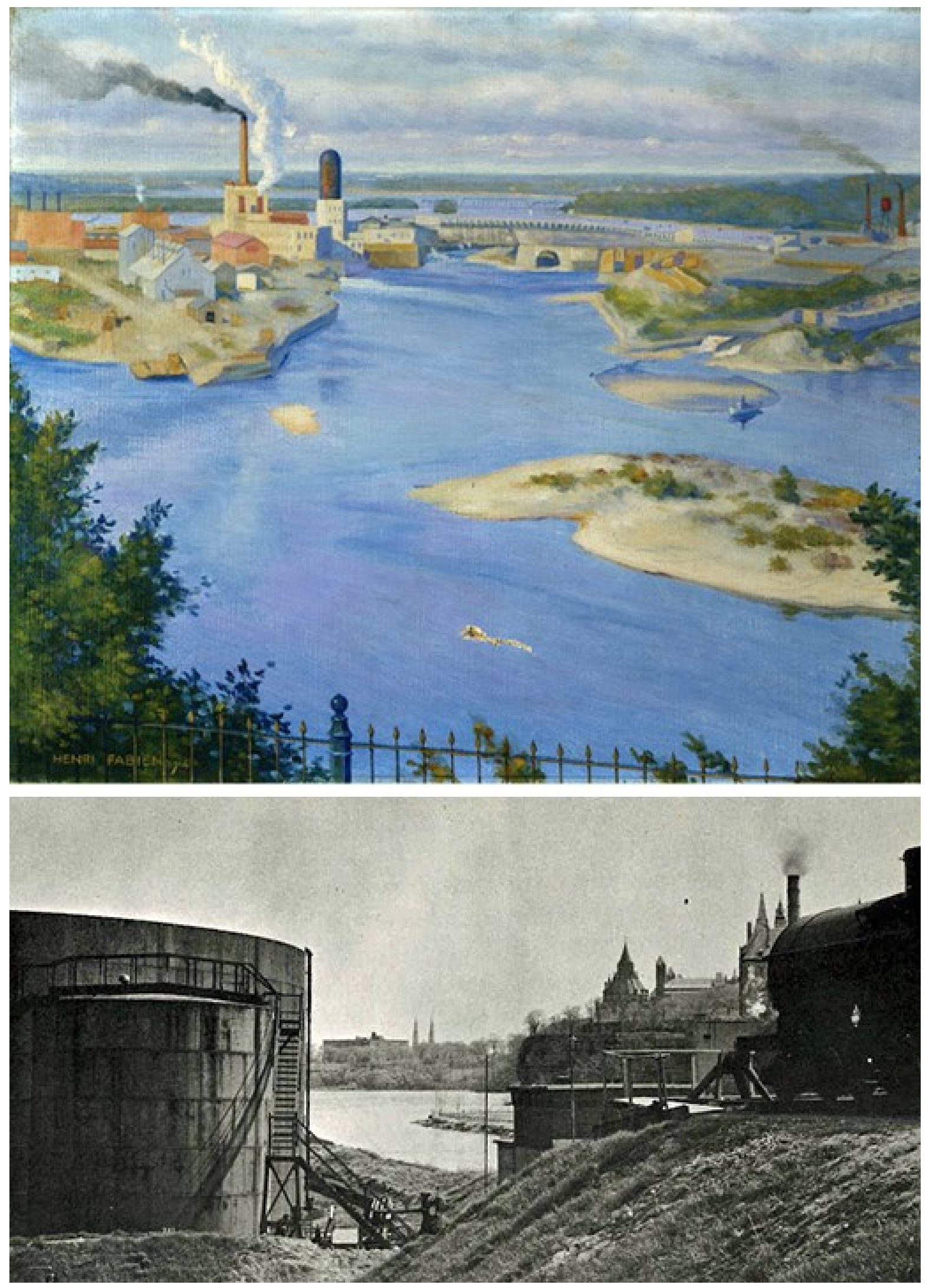

Figure 6: Glorified Pollution 


\section{The Importance of Place}

The Chaudière Falls was more than just one of the places where the Anishinabeg nation came to have their tobacco ceremony. In the interview with Albert Dumont, elder of the Anishinaabe people and resident of the Mi'kmaq reserve in Quebec, he spoke about the Chaudière Falls as being the trunk of a great pine tree; while the needles and branches of the tree are sacred, they are not as vital to the survival of the tree as the trunk. Likewise, while other places are considered to be holy places, none are as holy or close to the spirit world as that of Chaudière Falls ${ }^{22}$.

The Chaudière Islands have a place in Anishinaabe legends. Even the great Wasakijak was said to have roamed the shores of the Ottawa River. Wasakijak is an immortal first being to the Anishinaabe peoples who was placed on earth to teach valuable lessons to mankind and to impart wisdom and guidance to the peoples. Their legends, language, oral history, and moral code are vital to the Anishinaabe way of life. As said on the First Nations Sacred Sites website,

"For First Nations, their identity, nationhood, and cultural survival are all interconnected to their relationship with the land and cannot be separated out from their specific lands. This inexorable connection is celebrated in oral histories, creation stories, ceremonies and cultural practices." ${ }^{23}$

The Anishinaabe people believe in the power of nature to heal the broken soul. In an interview that I conducted with Albert Dumont on January 27, 2018 he gave an account of his encounter with nature as a great healer and he talks of his journey to healing from a place of addiction and low morale ${ }^{24}$.

"I had severe addiction issues; I'm celebrating 30 years of sobriety in April. And there was a small river, a secluded river, where there were falls and rapids, where I went to find the strength to stay strong and in my sobriety. And if that small falls on a secluded river could fix somebody

\footnotetext{
22 (Dumont 2018)

23 (Indigenous Corporate Training Inc. 2018)

${ }^{24}$ (Dumont 2018)
} 
like me who had a severe addiction, then what could a grand place like Akikodjiwan do for the wellness of all people? For me, that's the way it is. And yet they say 'no, we're going to build condos.' It's mind boggling; spiritually mind boggling, emotionally mind boggling, psychologically mind boggling... We don't appreciate what we're losing here. And I'm not just talking about the Algonquin's, but the people in Ontario and the world. ${ }^{25}$ ”

In this interview, Dumont affirmed that this is a spiritual place for the wellness of all people of all different religious backgrounds and beliefs. He believes this is not just a place for the Anishinaabe to enjoy but a place for all people ${ }^{26}$. He is suggesting that the government can still make this site a marketing of a geological object for public consumption and for enjoyment without placing architecture on the site.

Unfortunately, countries which have previously been colonies of the British state have lost their sense of place. Anthropologist Arturo Escobar delves into the contemporary social, cultural, and biological life in the global age and tries to understand the inner workings of everyday people's lives. Although his research focusses on the Afro-Columbian civilian, his work can be applied to the broader spectrum of colonial behaviors. His writings strive to exhibit the cultural politics of place, the relations between nature, technology, and culture, and the play of identity and difference. In his book Territories of Difference: Place, Movements, Life, Redes, Escobar has a quote which properly expresses how coloniality affected the Canadian psyche.

${ }^{25}$ (Dumont 2018)

${ }^{26}$ (Dumont 2018) 
"Coloniality refracts the heterogeneity of human relations into discrete objects, empties the world of ecological relationships, and then reconstitutes a closed world according to a colonial order of power" (Escobar, 2008) ${ }^{27}$

Coloniality turned places into objects which can be owned and controlled. Humans' relationships with others, Mother Nature, and their community have been remodelled into a closed world where the colonial culture contains all the power. Anthropologist Edward T. Hall explains how these closed systems become separate entities which override their original function, while the initial intention becomes lost in the self-preservation of the system.

"It is characteristic of all extension systems to be treated as distinct and separate from the user and to take on an identity of their own. Religions, philosophies, literature, and art illustrate this. After a time, the extended system accretes to itself a past and a history as well as a body of knowledge and skills that can be learned. Such systems can be studied and appreciated as entities in themselves."28

In this way, Edward T. Hall explains that systems such as the judicial, educational, and institutional systems in which the average Canadian citizen resides in has become flawed. The Federal Heritage Building Review Office, which was originally put into place by the NCC in the 1950's under the threat of the extinction of Canada's historical industrial buildings being demolished due to the Greber Plan, now has lost track of its original intended purpose; to protect aspects of Canadian History that are in danger of being forgotten [see figures 7 and 8: "Garden Plan of Victoria Island as Industrial Parkland" and "Industrial Parkland Sketches before Portage Bridge", respectively]. However, in the way these buildings are being preserved, there is information and history that has been neglected. In the case of the

${ }^{27}$ (Escobar 2008)

${ }^{28}$ (Hall 1976) 
Thomas Wilson Carbide Mill, the word usage, focal points, and omission of history retells the story of the Mill in a way that neglects the original owners and leasers of the land, the Anishinaabe peoples. 


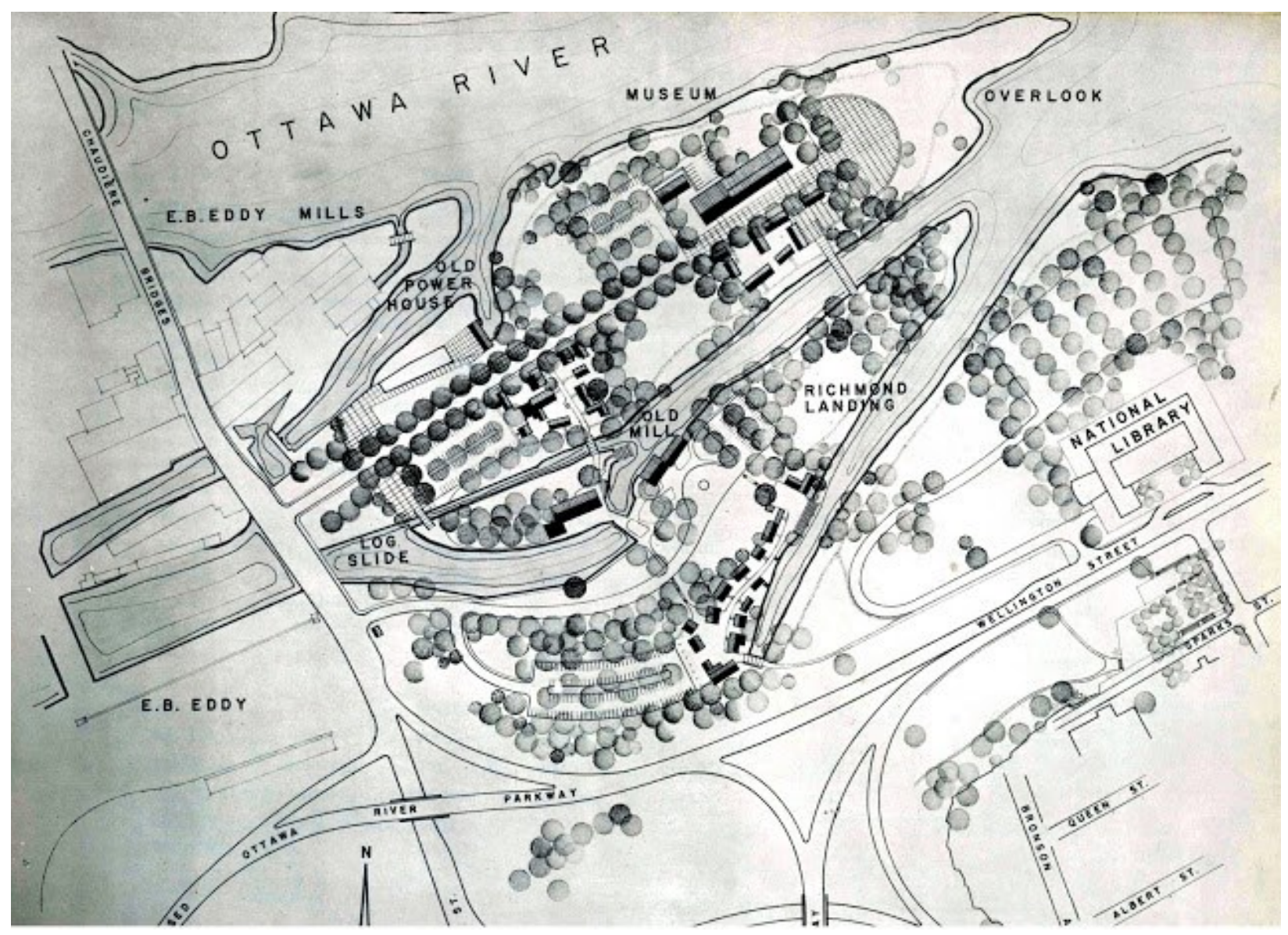

Figure 7: Garden Plan of Victoria Island as Industrial Parkland ${ }^{29}$

${ }^{29}$ (Urbsite 2012) 


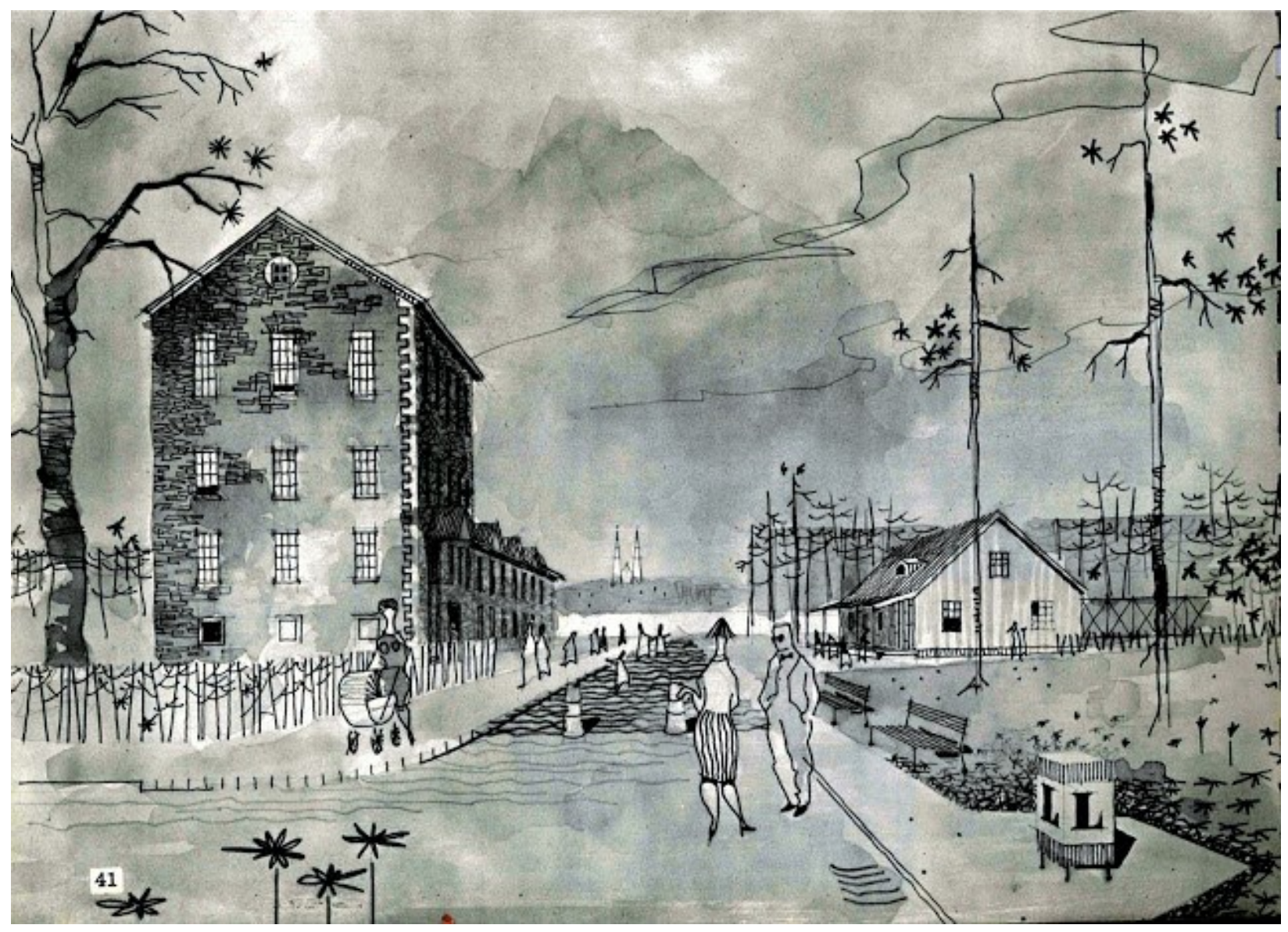

Figure 8: Industrial Parkland Sketches before Portage Bridge ${ }^{30}$

${ }^{30}$ (Urbsite 2012) 
In every document, story, and narration, there is always an omission of facts; this does not always reveal malicious intent, but it does reveal that the author does not feel that it is relevant to the plot or the purpose of their writing. In the figure below titled 'Not Applicable' [Figure 9], we see how the choice of language reveals a hidden story that reveals the author's biases and prejudices as well as their omission of facts. In the top section overlaying the whole picture, we see the English version of the Carbide Mill's Federal Heritage Building Report (FHBRO) - a minimized version of the longer 21 page review, which is shown in the middle section of the picture. This English online version contains no mentions of the land belonging to the Anishinabeg nation and under "Historical Information: Significant Dates" one can find only the words "Not Applicable", even though only 10 years earlier it was provocatively occupied as the 'Native Embassy' while the native people gathered to petitioning the government. The bottom of the figure shows a newspaper clipping where the Native Embassy is presented as a buried artifact that even though the facts were made public, they were described in a language that depicted native peoples as 'stragglers', who 'resist' authority, who make 'demands', and have 'violent confrontations' on parliament hill, while mentioning little to nothing from the perspective of the native peoples. The writers specifically say, "The NCC said they made an arrangement with the illegal tenants last week. In return for free airline tickets home, the Indians agreed to move out by 6 p.m. today." [Italics added to provide emphasis] The newspaper writers are insinuating that the land that the native people occupied in 1975 is not native land although the Victoria and Chaudière Islands were unceded and had never been traded, surrendered, or incorporated in a Treaty, making it -according to the Proclamation of 1763, Algonquin Territory; not to mention that the whole of Canada was originally completely native owned until French and English settlers immigrated here.

\footnotetext{
"Therein lies the meaning of the white fantasy about Indians- the problem of the Indian image. Underneath all the conflicting images of the Indian one fundamental truth emerges: the white man knows he is alien and he knows that North America is Indian- and he will never let go of the
} 
Indian image because he thinks that by some clever manipulation he can achieve an authenticity which can never be his." Vine Deloria Jr. in The Pretend Indians ${ }^{31}$

This quote reveals a hidden story behind the intentions of people who wish to disqualify Indigenous people's right to land and their culture. The fact that the native people still play a role in society is an inconvenience because it reminds all the cultures who migrated to North America that they are not the authentic and original peoples of this land. The Windmill developers are creating a new story where they are the main protagonist and the rightful owners of the land.

${ }^{31}$ (Bataille and Silet 1980) 


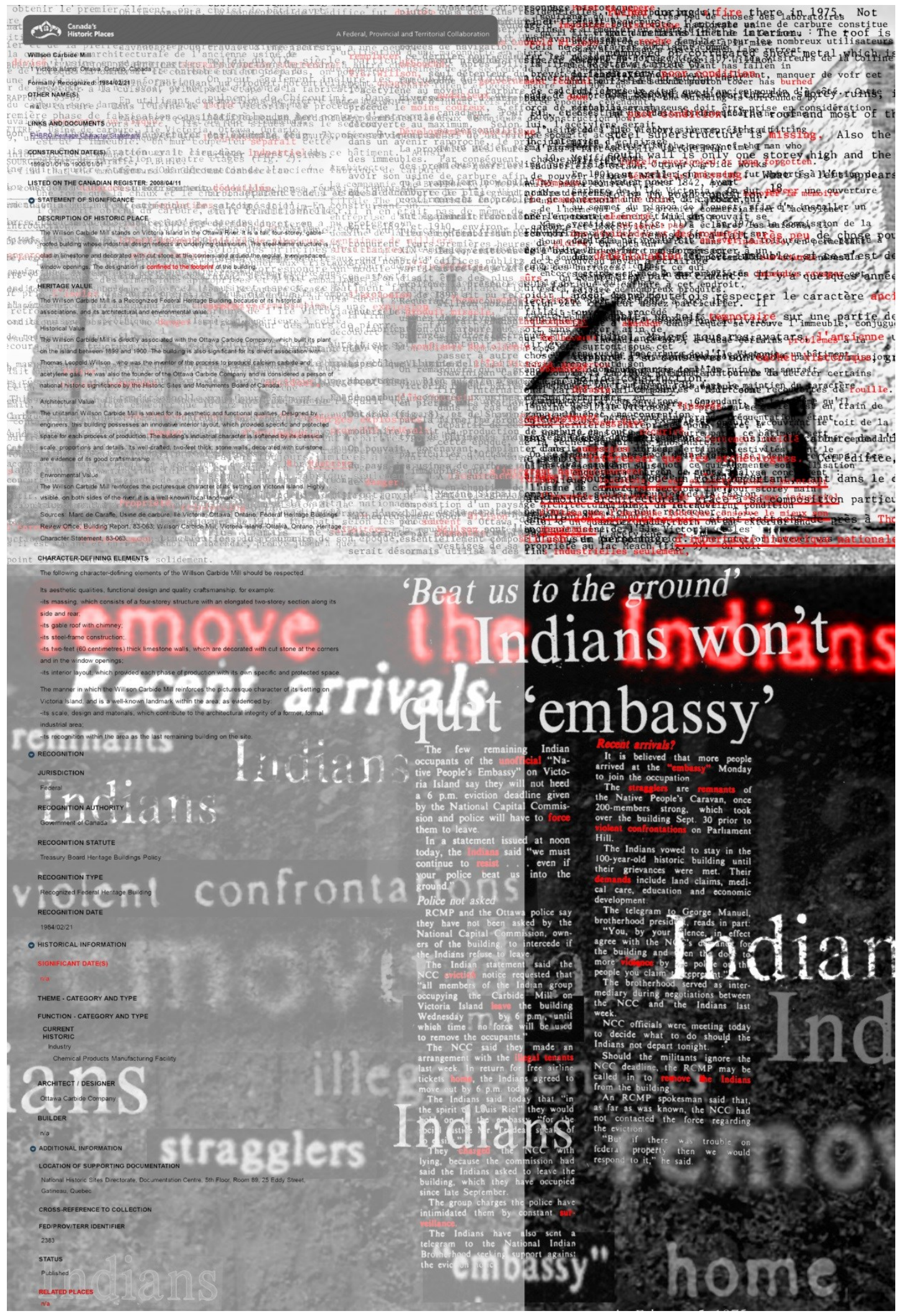

Figure 9: Not Applicable 


\section{Healing the Land}

Health is measured not only in physical wellness but also mental, emotional, and spiritual; some sources say that there are seven dimensions of wellness- where they include social, environmental, occupational, and intellectual categories ${ }^{32}$. Since the native people view the land as a personified entity, when talking about the healing of Asinabka there can be many different approaches to rejuvenating the site.

“...For the Earth is your Grandmother and Mother, and She is sacred. Every step that is taken upon Her should be as a prayer." Black Elk's account of White Buffalo Woman during a pipe ceremony $^{33}$

In a spiritual sense, the land was originally used for sacred purposes, but was converted to a place of industry and was infiltrated by what elder Dumont considers the pollution of greed. ${ }^{34}$ Money became a higher priority to these corporations. Even the construction of the Carbide Mill was for securing future profit. The knowledge that the previous carbide mill by Dominion exploded due to the improper handling of the materials required a solid 2 foot thick wall and well planned construction to segregate the dangerous materials and prevent them from mixing. ${ }^{35}$

Since these islands were of industrial usage, the public was not allowed on the site. The Falls, which had been a site of healing for all the people, became unreachable, first by the construction of the electric hydro dam in 1910 then later by the fences and zones put up by the government and industries. This natural and vital gathering space became unvisitable.

Verna McGregor, a former National Coordinator of the National Aboriginal Circle Against Family Violence, reveals that after the building of the parliament buildings native women avoided the Victoria

32 (UC Riverside 2014)

33 Page 79 (Walter Phillips Gallery Editions 2005)

${ }^{34}$ (Dumont 2018)

35 (Bureau D'Evaluation des Edifices Federaux a Valeur Patrimoniale 1983) 
Island site due to the possibility of rape and harassment; so many natives avoided visiting the Islands altogether. $^{36}$ The emotional and cultural clashing between the natives and the industrial workers on the islands became intolerable and consequently the native peoples left and their presence diminished on the site. Not until the Native People's Caravan of 1945 would indigenous people start to reclaim their presence on the islands again ${ }^{37}$.

The greed from the industrial era left a physical trace on the islands. In 2014, Windmill Development commissioned an engineering group -DST Engineering Consultants- to do an Environmental Site Assessment for the land to check the toxicity of both the ground and the groundwater for the Chaudière Island and the Victoria Island. Due to this assessment, Windmill - who initially requested \$124 million from the city for the remediation, removal of the soil, building rehabilitation, demolition, and environmental design and infrastructure work- now wants the city to give them $\$ 62$ million Canadian dollars to clean up the site in order to build their $\$ 1.2$ billion Zibi development, which is planned to take place on Chaudière Island, Albert Island, and on the shores of the Ottawa River on the Quebec side [see Figure 10]. ${ }^{38}$

"Money Matters" [figure 10] focusses on the realities of money and numbers on the Chaudière and Victoria Island sites. The island has been divided by invisible lines placed by the government. These lines make up zoning designations and parcels of land. The land is partitioned and analysed based on its perceived Western monetary value. The cost and revenue is placed directly on the island to show what can or will be gained from the site. Considering the indigenous people only receive $\$ 100 /$ year (contract renewable every 20 years) for leasing the land, it can accurately be stated that the Indigenous people are not being compensated properly for the resources they own.

\footnotetext{
${ }^{36}$ (Smith 2011)

37 (Circle of All Nations 2014)

${ }^{38}$ (Payne 2016)
} 
Although the Carbide Mill was vacated in 1945 and has no longer been producing pollution actively on the site, the site assessment confirmed areas of environmental concern, especially where the former acid storage tanks, former sulphite storage, various sites that contain fuel, oil and kerosene, and chemicals used to be located. ${ }^{39}$

\footnotetext{
${ }^{39}$ (Payne 2016)
} 


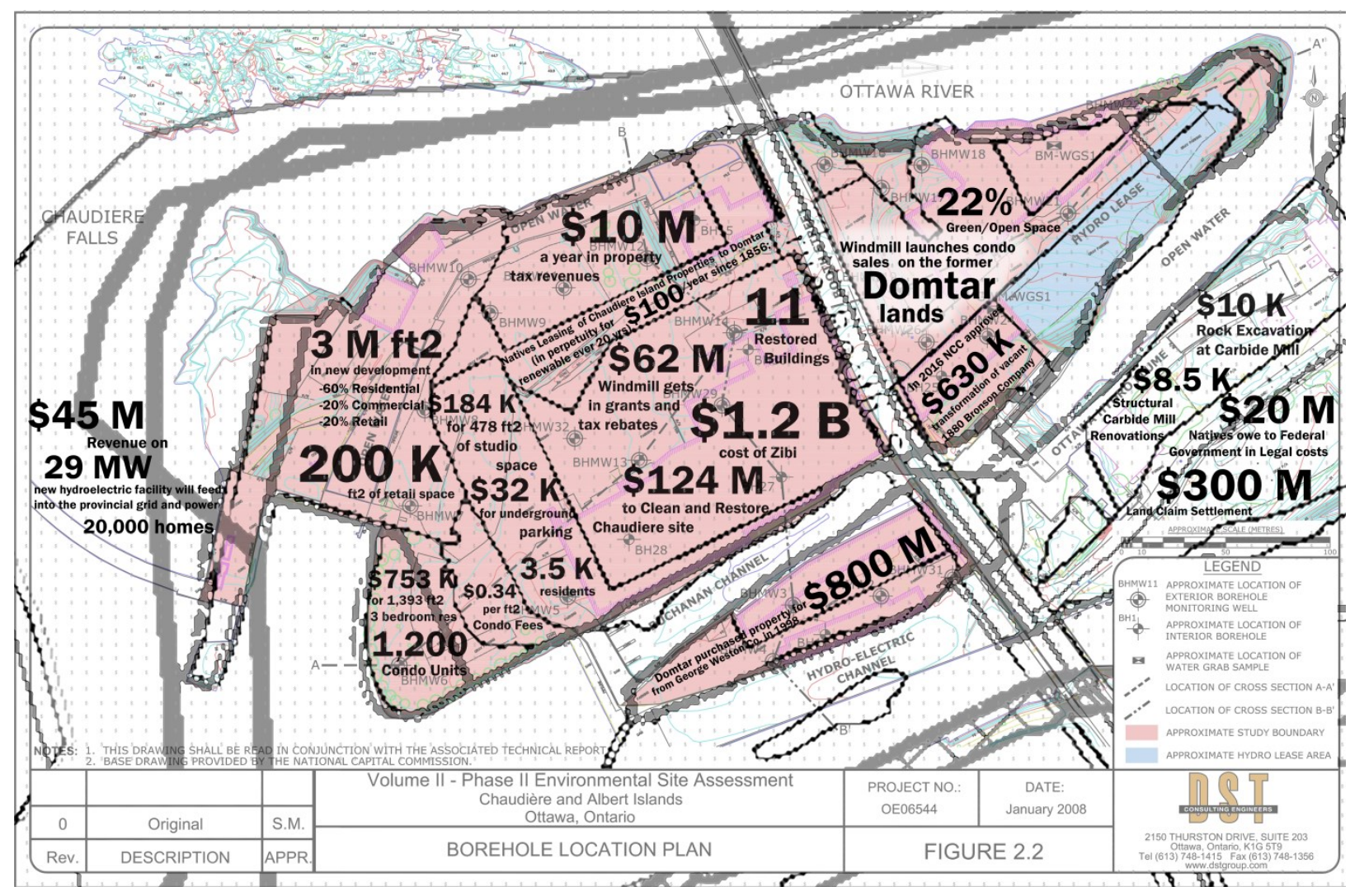

Figure 10: Money Matters 
The $21^{\text {st }}$ century marks a new era that is cognizant of the importance of environmental sustainability and conservation of the earth. This happens in direct response to the effects of the Industrial Era. This new era is based on the principles of sustainability and the realization that the earth would be dying if we continue to deplete its resources. This knowledge, which the indigenous people have always had and have foretold in their Seven Fires Prophecy, has affected the younger generation's mentality of sustainability and concern for pollution's effect on the planet. Certain processes - such as the displacement of polluted soil to other locations- do not solve the problem of land pollution and just move the problem somewhere else. ${ }^{40}$ Therefore, scientists are starting to study how to cleanse the land so it can be reused by removing the contaminants from the soil. This is important because soil contamination has serious long-term implications and deleterious effects on ecosystems, properties, people, and animals that may cause large scale die-offs or sickness, that in some cases can be permanent. $^{41}$

When the soil is considered contaminated, this could refer to many different types of toxins. In Canada, there are estimated 30,000 contaminated sites as of 2010 , which are polluted with heavy metals, hydrocarbons, creosote, organic and biological compounds, and other chemicals and toxins introduced to the site. ${ }^{42}$

In modern biological and environmental studies, there are different kinds of soil remediation that can be used to treat contaminated soil, depending on the level of toxicity and the type of toxin prevalent to the soil. Flora based treatments, which include microbial remediation (uses microorganisms and bacteria to either degrade organic contaminants, or bind heavy metals with inert and less bioavailable forms. The phytoremediation uses living green plants for decontaminating soil. Lastly, mycoremediation uses fungibased technology to decontaminate the soil. These processes are based on the concept that nature will

\footnotetext{
40 (EPAC 2017)

41 (EPAC 2017)

42 (Campbell 2010)
} 
cure itself over time and is known for being a low cost and less invasive treatment. Unfortunately, these treatments take longer than excavation and replacement of the soil, and the process can only extend as deep as the root systems can reach. ${ }^{43}$ Some other forms of remediation involve more invasive means such as $^{44}$ :

- $\quad$ Thermal Soil remediation: heating the soil, or burning the toxins out of the soil.

- Air Sparging: removing volatile organic compounds, or VOC's, from the soil by injecting pressurized air causing the hydrocarbons to change into a vapor state and then the off vapors are vacuum extracted.

- Encapsulation: separating the soil from the contaminants by mixing elements such as lime, cement, or concrete preventing it from spreading into other uncontaminated soil.

In my interview with elder Albert Dumont in January 2018, he was asked what the indigenous method of cleansing the land would be. His perspective was to let Mother Nature purify the lands naturally by the use of plants native to the land and by the natural flooding of the Ottawa River onto the site, like it happened in 2017 [see Figure 11]. He believes that, given the chance, the earth will cleanse itself [seen in Figure 12: Algonquin Sign on Victoria Island]. In the meantime, he suggests that the lands be opened up and turned into parkland for the use of the general public. In this way, people can enjoy the Falls while gathering together and witnessing the healing and return of the natural state of the island. ${ }^{45}$

\footnotetext{
${ }^{43}$ (EPAC 2017)

${ }_{44}^{44}$ (TechnologyWater 2014)

${ }^{45}$ Dumont expresses that the Anishinaabe people understand that the land can never been returned to its initial untouched condition but it is his goal that the land become healed to the point where it is no longer polluted and becomes an area of healing again. (Dumont 2018)
} 


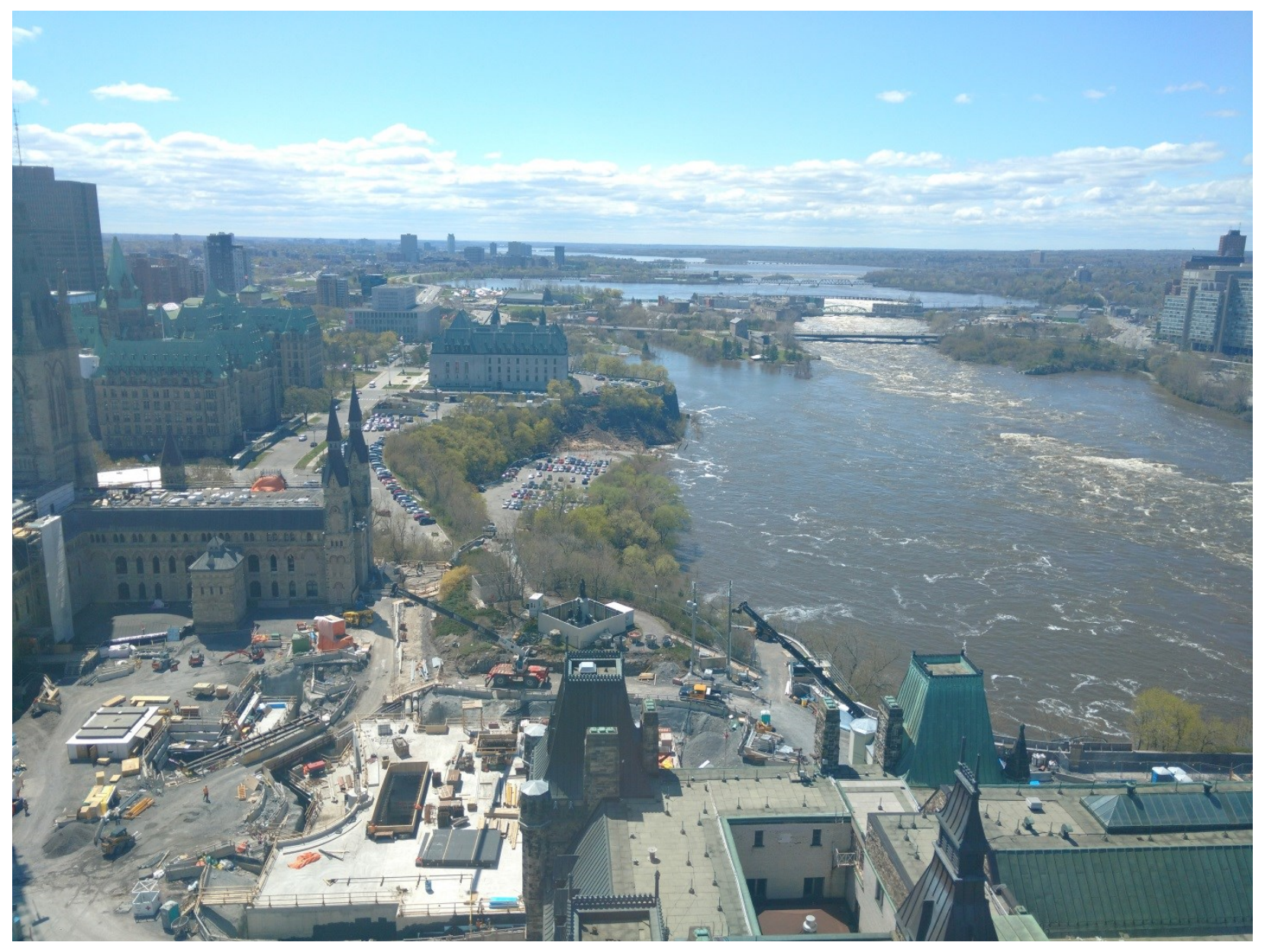

Figure 11: 2017 Flooding of the Ottawa River (taken by Lauren Stoymenoff) 
Kıvagosenımıgowag kıajl-gıkadjitöyeg kibahigâdeg awaso akîns ningo-bibôn minigik kidji-anwebîmigak.

The Anishinabe elders of the Algonquin nation ask that you please respect the closure of this area for a year to allow a period of healing for the land.

\section{Les anciens Anishinabeg de la nation algonquine vous sauraient gré de respecter la fermeture de}

Figure 12: Algonquin Sign on Victoria Island 
When given the chance, nature heals itself over time. Flooding is a natural and positive process for cleansing that is used to this day. In 2017, the Ottawa River flooded naturally and covered parts of Victoria and Chaudière Islands [See Figure 11]. The flooding of the land can be interpreted as asserting nature's dominance of the site and that it should not be developed until the land is cleansed; it can be seen as Mother Nature revolting against the Zibi development. As a personal reflection pieces [Figure 14: Inescapable Flooding], there is a visual study of the land when flooded which shows the unstoppable power of nature. We see the pictures of the flood of 2017 collages with an overlay of Windmill's plan to divert the storm water from the site. The pictures show how unrealistic the storm water plans are and bring to attention one of the flaws that the development has in its design. Bringing to attention the hazards of building condominiums on the site will turn investors away from Zibi and give more time for the Indigenous people to claim their lands back from the developer.

In figure 13, Jim Oshkineegish's illustration of a bird is collaged in a picture to show the adaptability and foresight of Anishinaabe people. The two overriding colors reveal the spiritual aspects (blue) and the wisdom (purple) of native pedagogies as well as a spiritual revival of the First Nations peoples; they are fighting for their lands and fighting for the chance to have their voices heard by the public and the government. The native people are connected to their land and the winged bird flying over the water represents their rightful position as overseers of the land- overseeing its transformation from a polluted site back into a spiritual site. The islands represent the spiritual journey everyone takes through their lives. In the words of Albert Dumont, "an island was often a place to pull up your canoe to the shore and sleep or cook, have some tea, regain your energy, before you continue your journey. On the River of Life, we have islands too. We have islands to rest, reenergize, to meditate..." and "an island is where you might want to ... reflect on your life, reflect on your wrongs. So an island is special, and it's surrounded by water. Just like a baby in the womb, it's surrounded by water." ${ }^{\prime 46}$

${ }^{46}$ (Dumont 2018) 

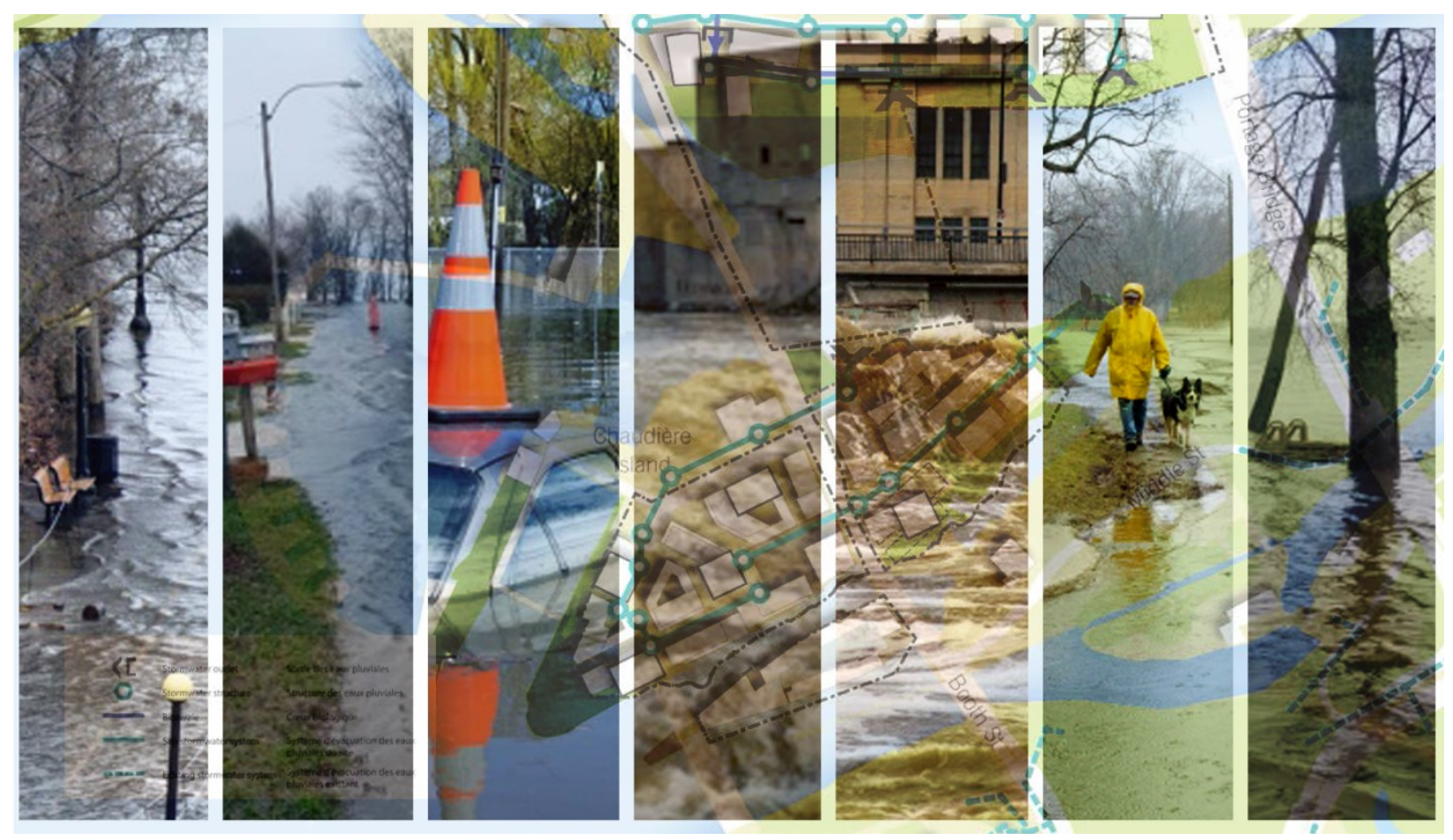

Figure 13: Inescapable Flooding 


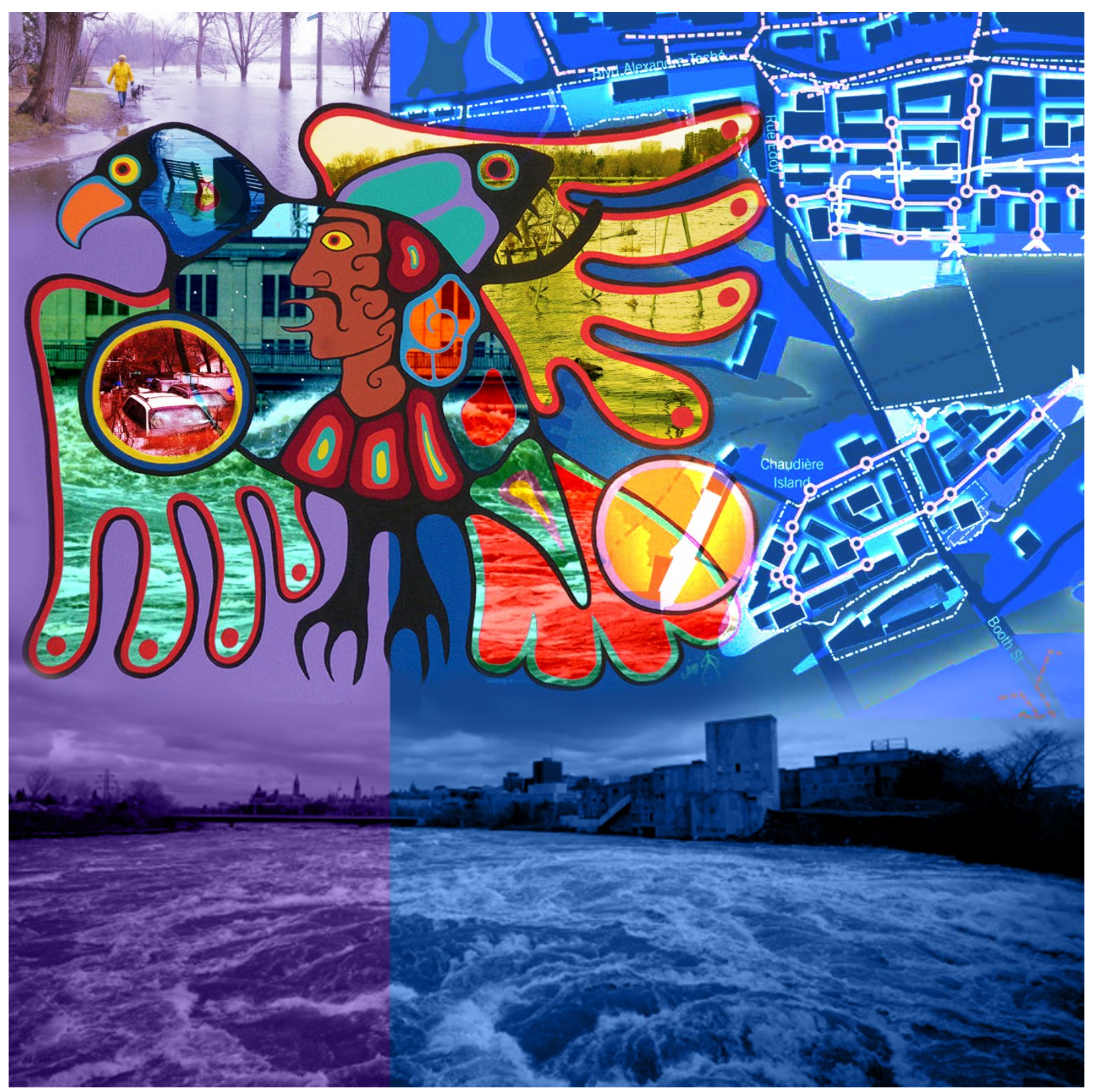

Figure 14: Artistic Cover-up of Flooding (Use of Jim Oskineegish Painting) 


\section{The History of the Native Voice}

Across Canada, there are different bands of Native Americans. There are 3 main groups of natives in Canada: the Inuit of the Arctic, the First Nations Peoples, and the people of mixed Native-European lineage called the Metis ${ }^{47}$. These main groups split into individual tribes and then divide again into clans. There were significant distinctions between each tribe and they could have different languages, clothing, customs, and heritage. Therefore, talking about Native peoples in general can lead to the issue of creating a "Pan-Indian" culture which is made upon the European stereotype of who a native is. In this thesis, the Anishinabeg Nation is the primary keeper of the Asinabka land and these people are still alive and thriving in today's society.

While I would not like to encourage the Pan-Indian culture, there are similar aspects of preservation that can be carried across these intertribal borders, as they reference a deep respect for mother earth and the passing of oral history through storytelling. I will make reference to the Mohawk people of Quebec and the Haida people in British Columbia as examples of how these particular native tribes view the continuation of their history and explain how their traditional practices play a role in how they express their culture. These particular moments in history have amplified the indigenous voice and have brought a new perspective on how cultural differences can manifest themselves in unexpected ways.

\section{Oka Crisis Movement; Kanehsatake: 270 Years of Resistance}

The impact of the Oka Crisis started a revolution by the native peoples and became one of the turning points for them in terms of respect and understanding from the government. Kanehsatake: 270 Years of Resistance by filmmaker Alanis Obomsawin, shows the Mohawk people protesting and blockading the road to their sacred site, Kanien'kéhaka, from being demolished to make way for a golf course. The standoff was between Mohawk protestors, the Quebec police and the Canadian army. This protest

47 (Indigenous and Northern Affairs Canada 2011) 
lasted 78 days and made international headlines. This event changed the way native people were viewed by the federal government- no longer would the government view them as weak. ${ }^{48}$

The Mohawk People first settled in the Montreal area in the $18^{\text {th }}$ century after being removed from their homeland in the Hudson River Valley. Starting with over $165 \mathrm{~km}^{2}$, the Mohawk people had slowly lost their land until they were left with only $6 \mathrm{~km}^{2}$ by $1956^{49}$. In 1990 , the land was approved by the government to become a golf course for the neighboring hotel. Before the bulldozers came to start the demolition of their sacred site, they tried peaceful means of preventing this desecration of their ancestral site ${ }^{50}$. Quebec's Minister of Native Affairs John Ciaccia wrote a letter of support for the natives, stating that "these people have seen their lands disappear without having been consulted or compensated, and that, in my opinion, is unfair and unjust, especially over a golf course."

But even with peaceful pleas and written demands to the government, the construction was still approved for the site. Not until the Mohawk people put up physical barricades and armed themselves defensively with guns as a show of force did the government start to pay attention. The government sent the federal army in response to the Mohawk's defensive position which escaladed the situation further.

This protest was visually violent, but still resulted in death: the death of a Mohawk elder. ${ }^{51}$ There were guns, violent and obscene words exchanged, and many people were injured in the process. Over 100 Mohawk people were charged and numerous people detained, but in the end the Mohawk people

\footnotetext{
${ }^{48}$ (Obomsawin, Kanehsatake 270 Years of Resistance 1993)

49 (Firsthand 2017)

50 The Sacred Pines were also the location where their ancestors had been buried for hundreds of years. Even with this knowledge, the golf course construction was still considered a valid option for the land.

${ }^{51}$ (Obomsawin, Kanehsatake 270 Years of Resistance 1993)
} 
regained the respect that should have been owed to them in the first place. They had pride in being able to protect their lands. ${ }^{52}$

In this protest, journalists, videographers, Hollywood actors, and many other people supported the Mohawk people digitally and over the media. The Mohawk voice was heard by millions of people and many rallied in support of the natives. A woman by the name of Kahentiiosta believes that if it weren't for the public's support and the widespread of information about the Oka Crisis, she and all the Mohawks living on the reserve would have been forcefully removed or massacred as 'another native problem $^{53}$. This is one of the first times in history where video and media were used to enhance the native voice ${ }^{54}$.

\section{The 'Return' of the G'psgolox Pole}

The movie documentary Totem: The Return of the G'psgolox Pol shows how much the native people value their artifacts. Although at first it may seem that the degradation of a historic mortuary totem pole is counter intuitive to the preservation of a culture, the documentary proves otherwise. In interviews with many of the people from the Haisla people, there is a deep respect for the totem pole and it's disappearance in 1929 was a huge loss for the people. The G'psgolox Pole is a mortuary pole, meaning that it marks a place of significance where people are buried: much like a gravestone marking. However, the pole is more than just a grave marker. The pole represents the wood craftsmanship of the people and the continuation of the craft through the generations. The pole tells a story by its use of animal caricatures; their position on the pole has a deep and spiritual meaning. While the pole is being carved, there is ceremony being performed and ritual practices that the carvers must follow. They give

\footnotetext{
52 (Obomsawin, Kanehsatake 270 Years of Resistance 1993)

53 (Obomsawin, My Name Is Kahentiiosta 1995)

${ }^{54}$ Sacheen Littlefeather gave a speech at the 45th Academy Award in 1973 in place of Marlon Brando's best actor award to protest the treatment of aboriginal Americans by the film and television industry and to bring attention to the Massacre at Wounded Knee.
} 
thanks to the tree spirit and they embody it with a new soul. The pole is raised by the community and many prayers of thanks and remembrance take place at this time. The pole is then left in this position until it naturally returns to the earth, symbolising the cycle of life and death.

When the G'psgolox Pole went missing, the Haisla people felt the loss like they had lost a dear companion in their community. When the pole resurfaced 60 years later in a Stockholm museum, property of the Swedish government, the Haisla people were outraged but attempted to peacefully find a resolution to the problem and have their pole returned. This scenario brings up questions about ownership and the meaning of Indigenous objects held in museums. The problem of indigenous artifacts being stolen is such a big problem that the National Museum of American Indian has repatriated more than 2,000 objects to 100 different Native communities throughout North and South America; in 2003 alone, the FBI returned over $\$ 400,000$ worth of stolen artifacts from the black market $^{55}$. This essentially projects a Western conservation concept onto an artifact that belongs to a different cultural mind set and makes the assumption that Indigenous people are a culture from the past.

In conclusion to the issue of the G'psgolox Pole, the Stockholm museum returned the pole but only after the native people carved a new pole that looked exactly like the G'psgolox Pole. However, by carving the new pole, the soul of the first pole was transferred into the new pole and because of this, could not be re-erected into its natural state. The old G'psgolox Pole, which the native people were able to bring back to their reserve, was not allowed to be exposed to the elements and had to be encased in a plexiglass container, still separated from the community in which it was first stolen.

In European-based cultures, there would be only the understanding that the pole was being preserved and that the pole would become an artifact that generations upon generations would be able to see. In

${ }^{55}$ (Sequeira 2016) 
a way, people might see the Swedish government as doing the right thing by keeping the pole safe as natural degradation would make the pole nearly unrecognizable by 2003 when the documentary was first filmed.

There is a lingering mentality that the Native peoples are a culture of the past, and that the culture is either extinct or dying out. However, Native cultures are still prevalent today although they have adopted modern technologies, much like the settler and pioneer people who first came to Canada. This flawed thinking justifies the stereotypes that the Euro-Americans and the world have towards native culture and gives them a reason to take elements of their culture away as prizes and artifacts, or to sell items of their design for a profit without the permission of the native peoples; like the Cowichan Sweaters of the Coast Salish people in British Columbia. ${ }^{56}$

Using pictures and stories to relay a message to the people is a tool the native people have been using for thousands of years; this is how they passed on their knowledge of craft, morality, and legends ${ }^{57}$. These stories are now starting to transcend into the realm of technology and film making. As the world changes, native people have always adapted and have always utilized the tools and technologies introduced to them as a means of enhancing their culture. The native people are now using film and art as a medium of communication to the global world to have their voices heard, to assert control over their own lives, and as a tool of personal and cultural expression.

"When Members of a community assert control over their own lives and culture, politically, socially and artistically, they go beyond oppression. Thus, control of our 'image' becomes not

\footnotetext{
${ }^{56}$ (Welsh 2000)

${ }^{57}$ (Hall 1976)
} 
only an act of subversion, but of resistance, and ultimately, liberation." Randy Horne in Spudwrench movie ${ }^{58}$

\section{Removal of Elements of Native Importance from FHBRO}

In the federal heritage building report, there is no mention of the native ownership of the land. In Section 2 of the heritage report, we see a reference to the owners of the building, the National Capital Commission, but not until section 6 is there any reference to the importance of place. ${ }^{59}$ In section 6 , while there is mention of the proximity of the Mill to the falls as its main source of power for the manufacturing process and the electricity requirement for the arc furnaces in the mill, there is no mention of the Anishinaabe people. ${ }^{60}$ Even in section 'C-Environment', and under point '8- Location' we see reference to Victoria Island but no reference to the native people leasing out the land or their 2,000 years of presence on the site before the industrial era in Ottawa. ${ }^{61}$

\section{The Building as an Experiment}

The federal heritage report talks about the Wilson Carbide Mill being constructed due to the explosion of the first carbide mill, Dominion Carbide Mill, in 1899. Due to this, the Ottawa Carbide Company had a monopoly on the acetylene market. The Thomas Wilson Carbide Mill was built on Victoria Island as an experiment hoping that it wouldn't blow up. ${ }^{62}$ The Mill was built on indigenous lands without concern to the safety of the people who owned the land, and who worked in the factory, or the worry about destroying the land due to another explosion. The first 11 pages of the FHBRO are dedicated to how the dangerous materials were housed in the Carbide Mill and how they could have triggered another

\footnotetext{
${ }^{58}$ (Horne 1997)

${ }^{59}$ (Bureau D'Evaluation des Edifices Federaux a Valeur Patrimoniale 1983)

60 Ibid.

61 Ibid.

${ }^{62}$ While there is no express mention of the word 'experiment' when referring to the Mill in the FHBRO, it is very heavily implied and surprise is expressed whenever mentioning the longevity of the building and the fact it did not explode like the Dominion Carbide Mill did.
} 
explosion if it weren't for the meticulous separation of materials and the $2^{\prime}$ thick walls that separated them. ${ }^{63}$ In the 'architectural composition' section of the FHBRO, it makes reference to the strict safety regulations in England that would have prevented the construction of the building in the first place. ${ }^{64}$ While the FHBRO refers to the regulations in England at the time, there was no reference to regulations for the Mill in Canada; which was the most likely cause of the explosion in the first Mill. Not only were there toxic chemicals being used, but the process of making the carbide required 20 arc furnaces. ${ }^{65}$ Due to the chemical construction of the carbide, if there was a fire at the plant, water could not be used to douse the fires, as contact between water and either the carbide, or the arc furnaces would create acetylene, which would cause a deadly explosion. ${ }^{66}$

In 2014, over 200 years after the construction of these industrial buildings, the toxic chemicals are still prevalent in the earth as seen in the Environmental Site Assessment Update completed by DST consulting engineers, so much so that it is not safe to host the public or the construction of new buildings ${ }^{67}$. Although the building is weathered and took fire multiple times, parts of the structure remain; but at the time of its construction, no one was sure that it would survive for this long. ${ }^{68}$

\section{Why the Carbide Mill is So Important}

The conclusion of the report states the highlights for why the building should be considered heritage and be protected by the federal government. The two main arguments brought to the attention of the reader are the fact that it is considered to have architectural heritage as well as being connected with a person of historical significance: Thomas Leopold [Carbide] Wilson (1860-1915). ${ }^{69}$

\footnotetext{
${ }^{63}$ (Bureau D'Evaluation des Edifices Federaux a Valeur Patrimoniale 1983)

64 lbid.

65 Ibid.

66 Ibid.

${ }^{67}$ (DST Consulting Engineers Inc. 2014)

68 (Bureau D'Evaluation des Edifices Federaux a Valeur Patrimoniale 1983)

69 Ibid.
} 
The design of the building was utilitarian; its function was the key design element. Its structure is more of an engineering design than an architecture design. It is designed to be more functional and practical than aesthetically pleasing. ${ }^{70}$

The person of historical significance, Thomas Leopold Wilson, was an inventor in the 1800 's who formulated the process of creating carbide, which is used in the manufacturing of products to this day. In his time, carbide was used industrially to light workplaces- although his original dream of it being used residentially was thwarted by the invention of the lightbulb. However, while he is a great inventor, this building created significant pollution, spillage, and waste on the island and its surrounding environment. The disregard for the environment over capital gain is a part of how this building and the activities that took place herein. This colonial worldview as it was applied at the time is against indigenous views, both during the Industrial era and today, and is something they do not wish to support, or share responsibility for, in any form. During the interview Elder Albert Dumont asked the question, “...who would want a relic, or an artifact, remembering someone or something that has polluted so much ?"71 $^{\prime 1}$ While the heritage statement reflects the positive elements of the Carbide Mill, it does not consider there are other viewpoints which contribute to the memory of the Carbide Mill. Dumont is not suggesting the erasure of history, but he does inflect that if the sole purpose of glorifying the building is to make polluters look justified in their actions, then the buildings should be removed. He says later in the interview that if the buildings can be of use then we should use them, but for the purpose of creating parkland, a green place, and a place of ceremony which the Anishinaabe believe should happen on the site today. ${ }^{72}$ In allowing the Carbide Mill to be protected for the sake of idolizing the polluters of the land, he believes we are sending a negative message to our future generations.

\footnotetext{
${ }^{70}$ Ibid.

${ }^{71}$ (Dumont 2018)

72 (Dumont 2018)
} 
The key elements stated in the FHBRO that make the Carbide Mill important have nothing to do with its location on the Victoria Island site. Therefore, a provocative argument could be made that as long as the building is remembered for its architectural appearance and its relation to Thomas Carbide, it could be located anywhere. This building could be disassembled and reassembled in another location. Another aspect of discourse is that the building is not in its original condition, considering that parts are missing from the structure [see Figure 15].

The first section, the four storey main building, is in excellent condition structurally, both on the exterior and on the interior. The interior however was ruined during a fire there in 1975. Not much remains in the interior. The roof is composed of corrugated sheet metal which is in very poor condition.

The second section, the two storey ruins, is in poor condition. The roof and most of the steel superstructure is missing. Also the south wall is only one storey high and the east wall is missing. What is left appears to be in good condition ${ }^{73}$.

In the federal heritage statement, there is a lack of historical association between the Mill and the land's deeper history. Considering its condition, the levels of pollution, etc. it could be argued that if the building was taken apart and different elements were reassembled in different specified areas throughout Ottawa, or in a single place, it would still maintain the same level of federal heritage significance. This would allow for the site to be cleansed more easily through natural remediation, which would later make way for any structures the Indigenous people propose for the site. In Figure 16 labelled "Floating Carbide Mill", we can see the dissociation of the building from the site. When compared with the timeline of the land, the Carbide Mill becomes less and less integral to the site's own deeper history.

${ }^{73}$ (Bureau D'Evaluation des Edifices Federaux a Valeur Patrimoniale 1983) 


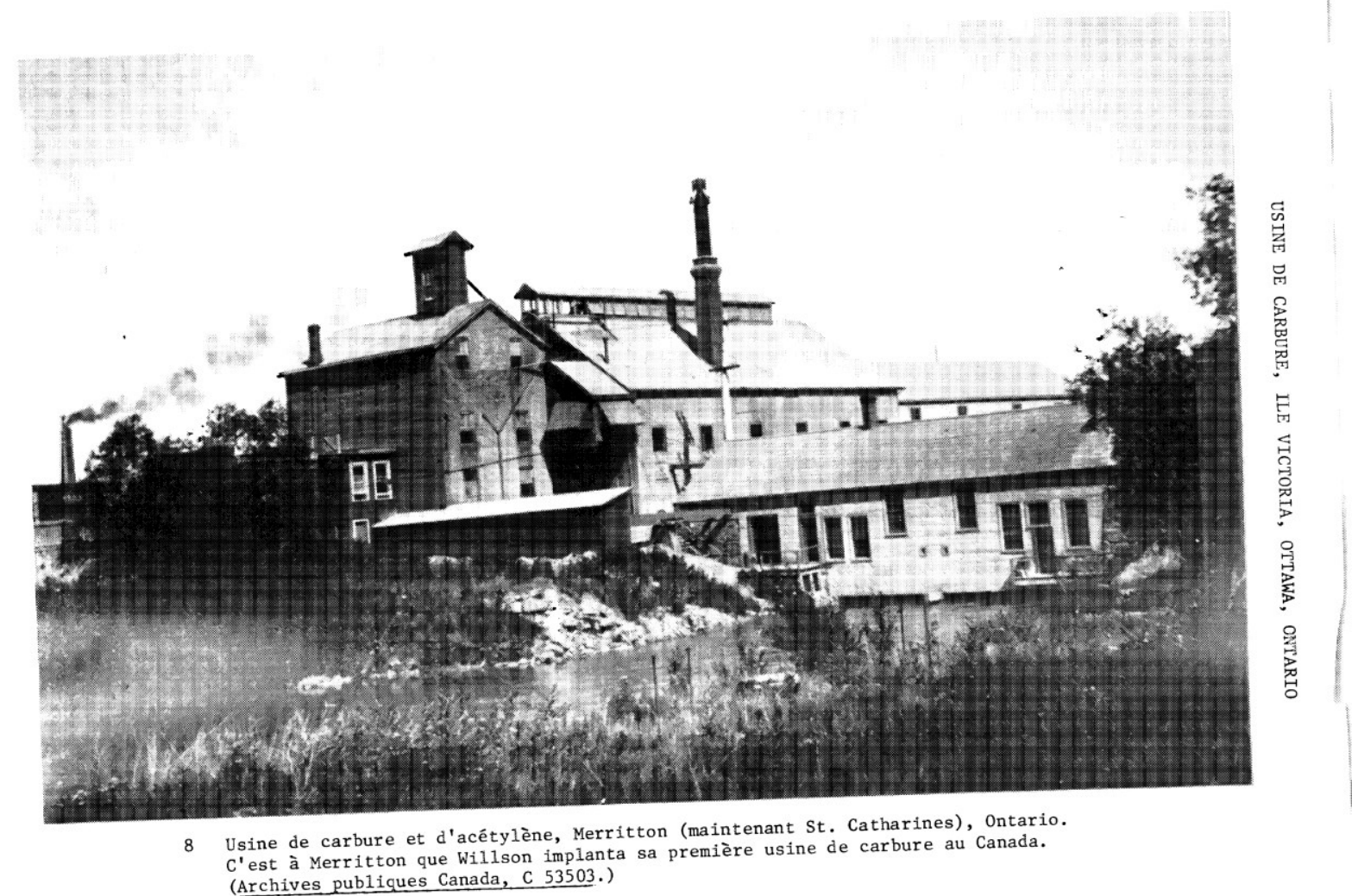

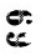

Figure 15: Carbide Mill Photo from the official FHBRO 


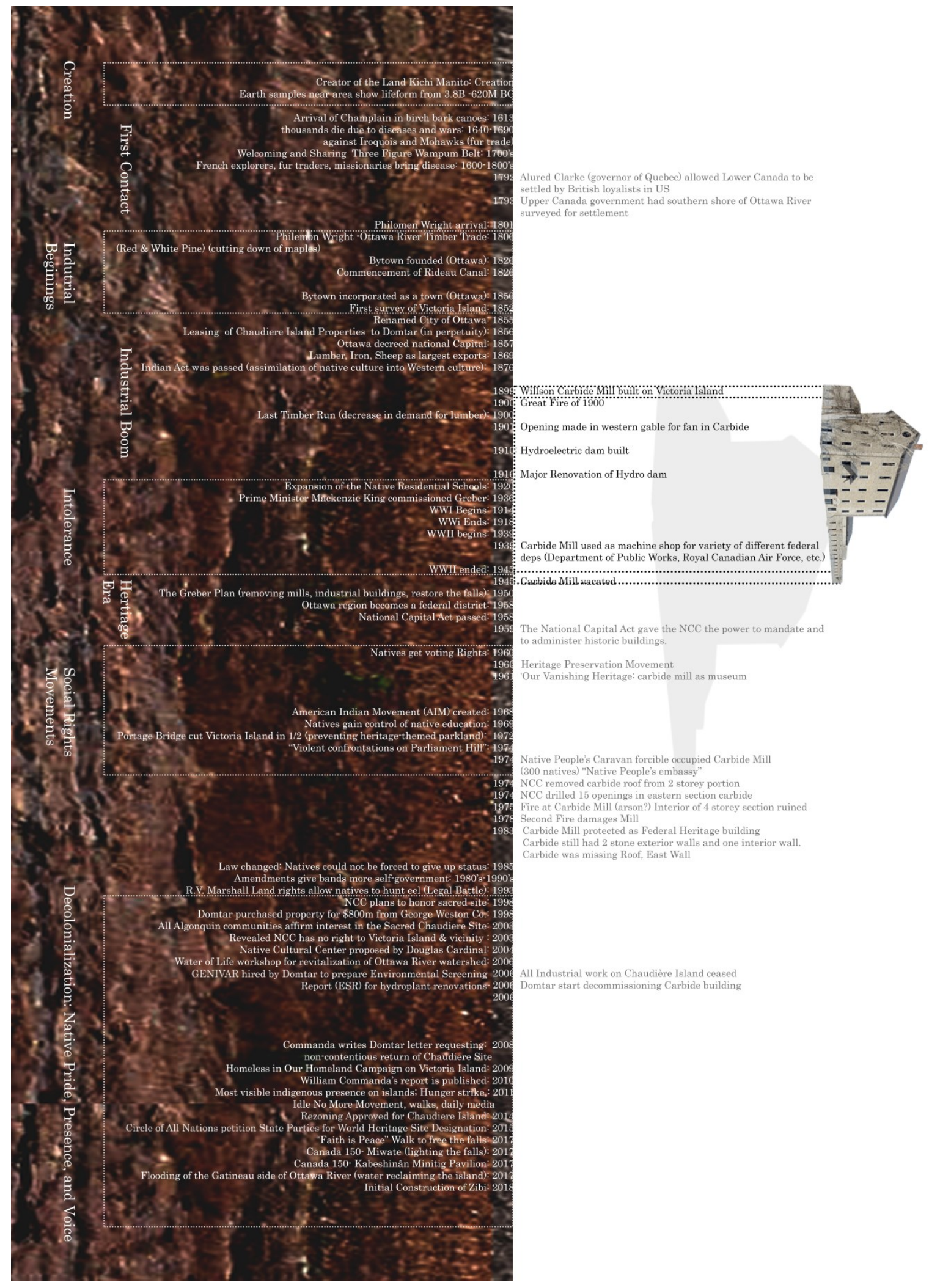

Figure 16: Floating Carbide Mill 


\section{Mìwàte Show}

The Miwàte Show is a clear example of how cultures who have good intentions towards each other can misconstrue the other's actions as harmful. The Mìwàte Show, in celebration of the Confederation of Canada begun 150 years ago, was meant to bring to the public's attention the Native peoples as a part of Canada. The show consisted of Indigenous traditional and modern music with a background of elaborate lighting of the falls on the downstream side of the Chaudière Falls and was in production for October and November 2017. ${ }^{74}$ The land, which had previously been banned from the public view due to its industrial nature, now allowed visitors to have a lookout onto the falls. The lookout carried information about native people and had elders and native representatives were available to talk to the public. The mentality behind this show was to acknowledge the native peoples; however, it sparked resentment within many of the indigenous people.

So how can an event like this be misconstrued? It all starts with the lack of communication between the government and the indigenous people. This divide, which has manifested since the first contact between these cultures, is still prevalent today. What the government fails to recognize is that they were celebrating the colonialization of the land and the attempts at assimilation of the native peoples through unforgivable means such as the residential schools, 60's scoop, stereotyping, and general treatment of the native peoples. Not only this, but the celebration of the falls, one of the most, if not the most, important sacred sites of the Anishinaabe and Algonquin peoples, was directed more towards the hydroplant, than the Falls. Albert Dumont and Commanda-Dewache both view it as similar to an entertaining side-show for tourists. ${ }^{75}$

Douglas Cardinal adds to the native narrative by stating, "The whole thing is so disturbing, not only to Algonquins, but for all Anishinaabe people from the Atlantic to the Rockies. It's not a play thing for the

\footnotetext{
${ }^{74}$ (Comber 2017)
}

75 (Comber 2017) 
entertainment of the dominant culture. It's a sacred site. If they did a light show at Saint Peter's square, ask the Pope what he would think." 76

Instead of considering the site as an aesthetic experience, it should be seen as a natural phenomenon and a place of spiritual power that has existed for thousands of years. The dam is chaining the falls and blocking the majestic qualities of the water and it is also the reason why the American Eel species and the Lake Sturgeon are becoming endangered. The dam prevents these species from travelling up the river and spawning, which destroys their natural feeding and bedding grounds. Not only are the Eel and the lake sturgeon animals that the native people respect and learn from, they were also key to the survival of the native peoples thousands of years ago and have never had any risk of endangerment before the construction of the dam. The falls are controlled in a way that prevents the water from decontaminating the islands through natural flooding. ${ }^{77}$ This slows the natural process of land remediation and allows for pollutants to remain on the islands. For these reasons, there is a movement called "Free the Falls" where peaceful walks and protests happen to bring attention to how the land and the people are affected by the falls being cut off.

However, the unchaining of the Falls, which are on Anishinaabe territory, will most likely not happen within the next few decades. This is because of several reasons; the main reason being that the falls produce much of Ottawa's hydro-electric power; at the moment the Falls contain a 29-megawatt generating station, the estimated power generated by this station can power 20,000 homes annually ${ }^{78}$. Another reason is that the water could produce some unexpected changes in the formation of the land and islands surrounding the falls as the water pressure and volume would become unregulated. The falls can never be brought back to their original splendor, and many of the activists know this, but they wish to have their falls back, or at least as close as possible to what they should be, under the known

\footnotetext{
${ }^{76}$ (Comber 2017)

77 (Circle of All Nations 2014)

78 (Pearson 2016)
} 
circumstances. The falls were a place of international gathering among natives [see Figure 17] from all over Canada and the United States and the Circle of All Nations, a global eco-community for over 20 years, wishes to revitalize this communion between settler allies, organization, and other international friends and partners and dissolve the concept of borders between peoples. ${ }^{79}$ These falls represent a place of history, remembrance, and spiritual connection between peoples, between the spirit and physical world, and between a person and their ancestors.

${ }^{79}$ (Circle of All Nations 2014) 


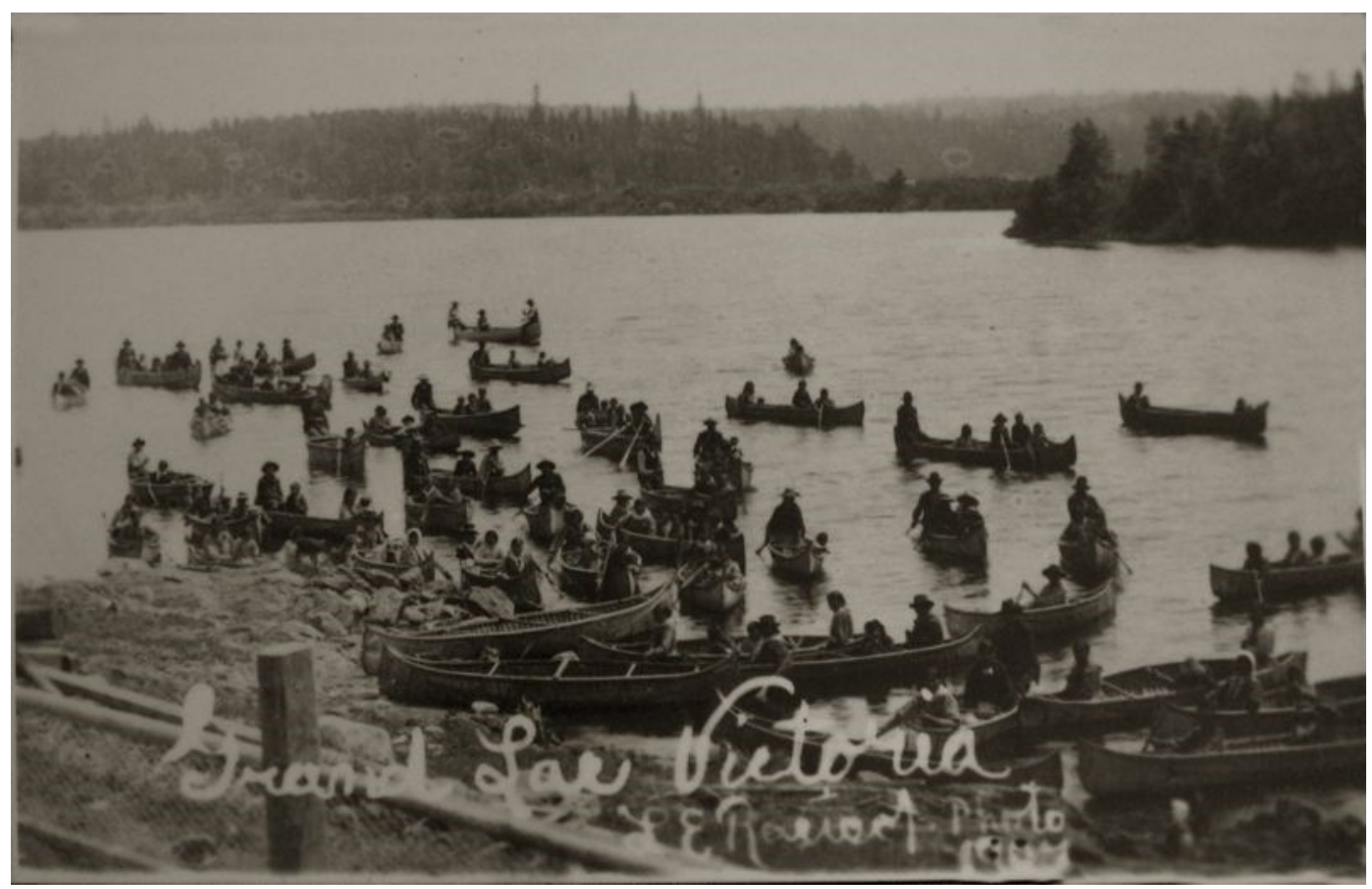

Figure 17: Chaudière Islands as Gathering Place for Indigenous and Non-Indigenous Peoples ${ }^{80}$

${ }^{80}$ (Urbsite 2012) 


\section{United Nations Declaration on the Rights of Indigenous Peoples}

Native people have a right to their culture. As of 2010, Canada endorsed the United Nations Declaration on the Rights of Indigenous People; although at the time the Conservative government called it an "aspirational document" and not legally binding. Not until 2016 did Canada agree to adopt the declaration and on June 11, 2008 Prime Minister Stephen Harper issued an official apology, now coined

"The Day of Apology"81. Therefore, Canada has agreed to do everything in their power to grant their Indigenous peoples rights, especially in concerns with their right to religious expression. Below are Articles 11 and 12 of the Declaration [italics added for emphasis]:

In Article 11,

1. Indigenous peoples have the right to practise and revitalize their cultural traditions and customs. This includes the right to maintain, protect and develop the past, present and future manifestations of their cultures, such as archaeological and historical sites, artefacts, designs, ceremonies, technologies and visual and performing arts and literature.

2. States shall provide redress through effective mechanisms, which may include restitution, developed in conjunction with indigenous peoples, with respect to their cultural, intellectual, religious and spiritual property taken without their free, prior and informed consent or in violation of their laws, traditions and customs.

In Article 12,

1. Indigenous peoples have the right to manifest, practise, develop and teach their spiritual and religious traditions, customs and ceremonies; the right to maintain, protect, and have access in

${ }^{81}$ (Fontaine 2016) and (Indigenous and Northern Affairs Canada 2015) 
privacy to their religious and cultural sites; the right to the use and control of their ceremonial objects; and the right to the repatriation of their human remains. ${ }^{82}$

Due to the wording in the document, Canada has opened the door to the breaking of its promise to the Indigenous peoples who have the right to protect or develop their historical sites, as this manifests their culture. When the government rezoned Chaudière Island in 2014, they were enabling the indigenous property to be at risk for development and they did this without the consent of the Algonquin peoples ${ }^{83}$. While this may have been the catalyst for the developer interest on the site, the direct violation was done when the government approved and allowed Windmill developers to plan and initiate their Zibi development. Albert Dumont confirms that the construction of Zibi will prevent his people, and all people, from having access to their religious and cultural sites (Article 12 of the declaration). ${ }^{84}$

\footnotetext{
${ }^{82}$ Copied directly from (United Nations 2008)

${ }^{83}$ Christopher Wong said First Nations people were not sufficiently consulted about what to do with land they consider sacred. The name of the Newspaper article is "Ottawa committee approves rezoning on sacred aboriginal site". (CBC News 2014)

${ }^{84}$ (Dumont 2018)
} 


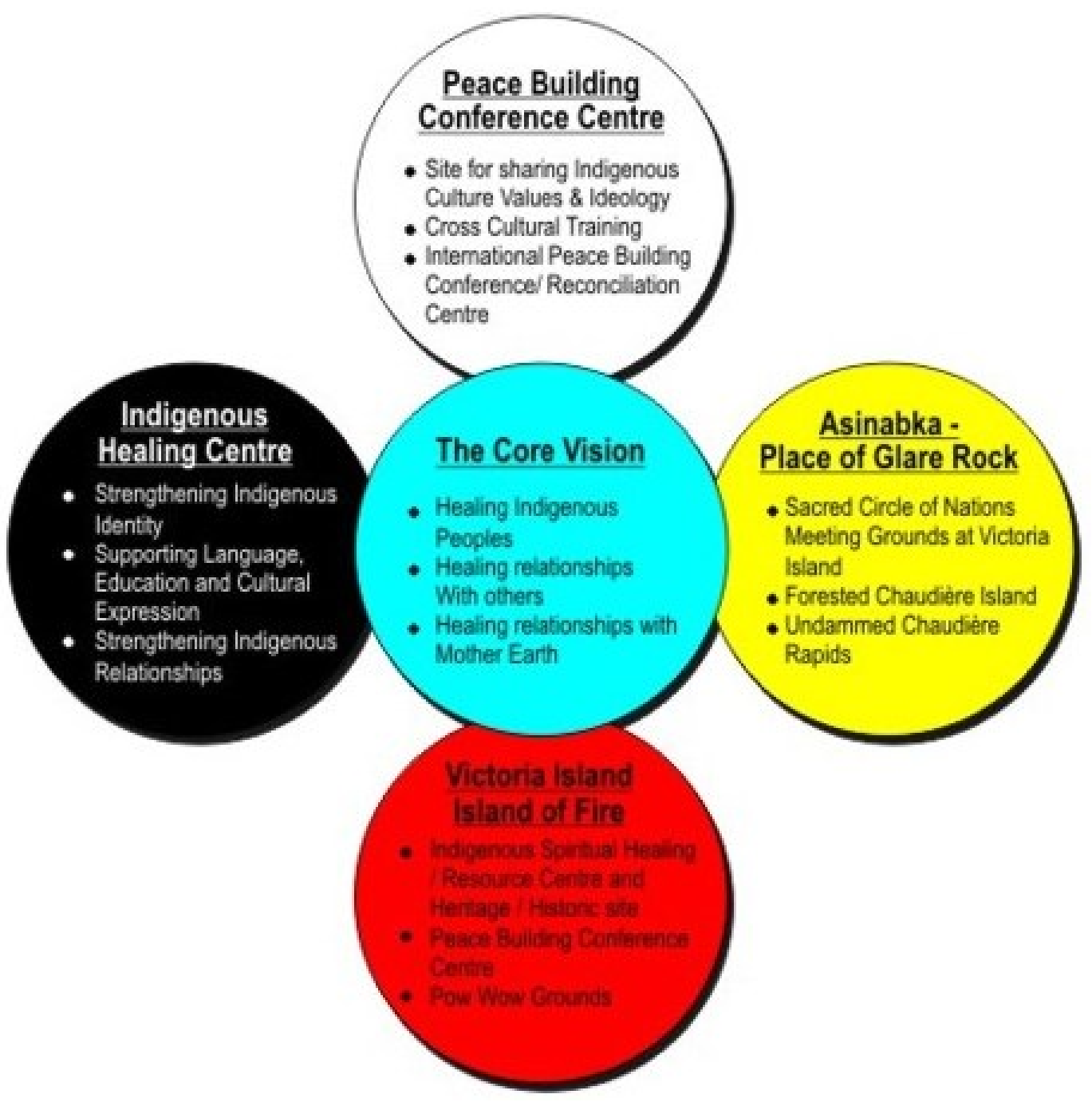

Figure 18: 2003 Circle Vision of Sacred Asinabka ${ }^{85}$

${ }^{85}$ Sacred Asinabka- Chaudière/Victoria Island Site as endorsed by the Algonquin Elders and Communities of Quebec and Ontario in 2002-2003 from (Commanda 2010) 


\section{William Commanda's Report}

The late elder William Commanda created a vision for Asinabka [see figure 18: 2003 Circle Vision of Sacred Asinabka], which is proposed for the Victoria and Chaudière Islands. He envisions the area to be a place to heal individual and collective relationships with Mother Earth; healing, strengthening, and unifying Indigenous Peoples and; healing relationships with all others. Not only is his intention to have this as a place for indigenous peoples, but also for all people, as we are all considered to be of the earth from an indigenous standpoint. ${ }^{86}$ William Commanda's personal consultation with all Algonquin communities resulted in all communities affirming interest in the Sacred Chaudière Site and support for his multi-pronged vision ${ }^{87}$.

William Commanda's vision, which he spent 30 years developing, is to have two buildings on Victoria Island designed by Indigenous Architect Douglas Cardinal, who is known for his design of the Museum of History/Civilization on the Quebec side of the Ottawa River (1989). ${ }^{88}$ The program for these buildings is located below in Figure 19.

The first of these buildings would be the Circle of Nations Spiritual Healing Center to Unify and Strengthen Indigenous Peoples. The program of the building would consist of elements that would rejuvenate and teach the native culture to people of all ages to cater to their physical, mental, emotional, and spiritual health.

The second building would be the Peace Building Center for all nations, to share the values and ideology of indigenous peoples. The program of this building would focus on international and intercultural relations with a focus on presenting the qualities of the indigenous peoples.

\footnotetext{
${ }^{86}$ (Kelly 2017)

87 (Circle of All Nations 2014)

${ }^{88}$ (Commanda 2010)
} 


\begin{tabular}{|c|c|}
\hline $\begin{array}{c}\text { CIRCLE OF NATIONS } \\
\text { SPIRITUAL HEALING } \\
\text { CENTRE TO UNIFY AND } \\
\text { STRENGTHEN INDIGENOUS } \\
\text { PEOPLES }\end{array}$ & $\begin{array}{c}\text { PEACE BUILDING CENTRE } \\
\text { FOR ALL NATIONS, TO } \\
\text { SHARE THE VALUES AND } \\
\text { IDEOLOGY OF INDIGENOUS } \\
\text { PEOPLES }\end{array}$ \\
\hline $\begin{array}{l}\text { SpiritualCeremonial Centre and } \\
\text { Elders' Gathering Place }\end{array}$ & $\begin{array}{l}\text { Peace building/environmental } \\
\text { stewardship 'Think Tank' }\end{array}$ \\
\hline $\begin{array}{l}\text { Cultural Revival - Arts, Crafts } \\
\text { Studio space; Museum/Gallery }\end{array}$ & Cultural Sharing/Racial Harmony \\
\hline Language Resource Centre & Conference Centre \\
\hline $\begin{array}{l}\text { Resource Centre/Campus for } \\
\text { Aboriginal University/College } \\
\text { Students in the capital city }\end{array}$ & $\begin{array}{l}\text { Think Tank/Meeting Space in } \\
\text { natural environment within the city } \\
\text { to facilitate deep reflection }\end{array}$ \\
\hline Healing Centre/Meeting Centre & Auditorium/Concert Hall \\
\hline $\begin{array}{l}\text { Archives/Library/Historic Research } \\
\text { Centre }\end{array}$ & Accommodations \\
\hline Medicines/Gardens/Greenhouse & United Nations Meeting Space \\
\hline Youth/Children Creative Space & Children's/Youth Museum \\
\hline $\begin{array}{l}\text { Traditional Knowledge/Ideology } \\
\text { Animation }\end{array}$ & Restaurant/Gift Store \\
\hline Research/Planning/Education & Museum/Gallery \\
\hline
\end{tabular}

Figure 19: Proposed Program for the Healing Center and the Peace Building Center ${ }^{89}$

\footnotetext{
${ }^{89}$ Table taken from (Commanda 2010)
} 
There are many positive results expected from the erection of these two buildings on the Chaudière Island and Victoria Island sites. The building program would cater to the mental, physical, emotional, spiritual, and social needs of the surrounding community as a whole as well as the indigenous community. The program would foster relationships between multiple cultures, Canada and the global community, between people and the earth, and people and their inner selves.

The center created would facilitate discussions on how the country and society needs to change for the health and wellness of all people. Through these discussions and in this safe space, healing between different cultural groups could happen. The socio/economic/health conditions of aboriginal people could be improved as we acknowledge the fair recognition of their right to land, resources, and respect. $^{90}$

The buildings would have spaces for creative thinking in arts and crafts and would allow freedom of expression. There would be places to showcase these artworks and Indigenous people would be more visible to the National Capital Region and the world. The buildings would become gathering spaces and host archives that can be accessible for researchers, universities, colleges, and other schools using a comprehensive articulation of Indigenous thoughts on global, environmental, and social justice issues. Through a native understanding of health, environmental stewardship, and peace-building techniques, the Canadian people can affirm aboriginal history and their rights while celebrating the Indigenous culture and heritage as The Sacred Jewel in the Nation's Crown. Overall, the maturation and selfrespect of Indigenous people in the Canadian psyche is what these building programs aim to do ${ }^{91}$.

It is not mentioned in the William Commanda Report on the Vision of Asinabka how giving back the lands to the Anishinabeg Nation will renew trust and be the most impactful action towards a formal apology by the federal government for the wrongs done to the native peoples throughout colonial

${ }^{90}$ (Commanda 2010)

${ }^{91}$ (Commanda 2010) 
history. By allowing the native people to build on their own land, they would be agreeing to break the cycle of capital-based crimes committed against the native people.

Architect Douglas Cardinal reflected on the fact that there is the War Museum (Moriyama \& Teshima, 2005) in Ottawa commemorating the actions of war but there is no building designated to peace. Cardinal advocates for this peace building to be built by the Anishinaabe people because they are a people of peace and do not resort to violence but to prayer and ceremony instead. In his words, architect Douglas Cardinal says, "Why do we glorify war so close to the islands of peace? We need some kind of monument for peace- peace is the Anishinaabe culture" ${ }^{92}$ While it is understood the war museum contains an ambiguous nature that can reflect war as well as peace, a National Peace Center would only ass to the message of peace and would allow for a different approach for the future of solving global issues. This peace center would be an incredible spokesman for the Canadian support on multiculturalism and would renew its status as a peace loving country. In the following figures [Figure 20, 21, and 22], Douglas Cardinal creates a conceptual design on the Asinabka Site.

92 (EquitableEducation 2014) 

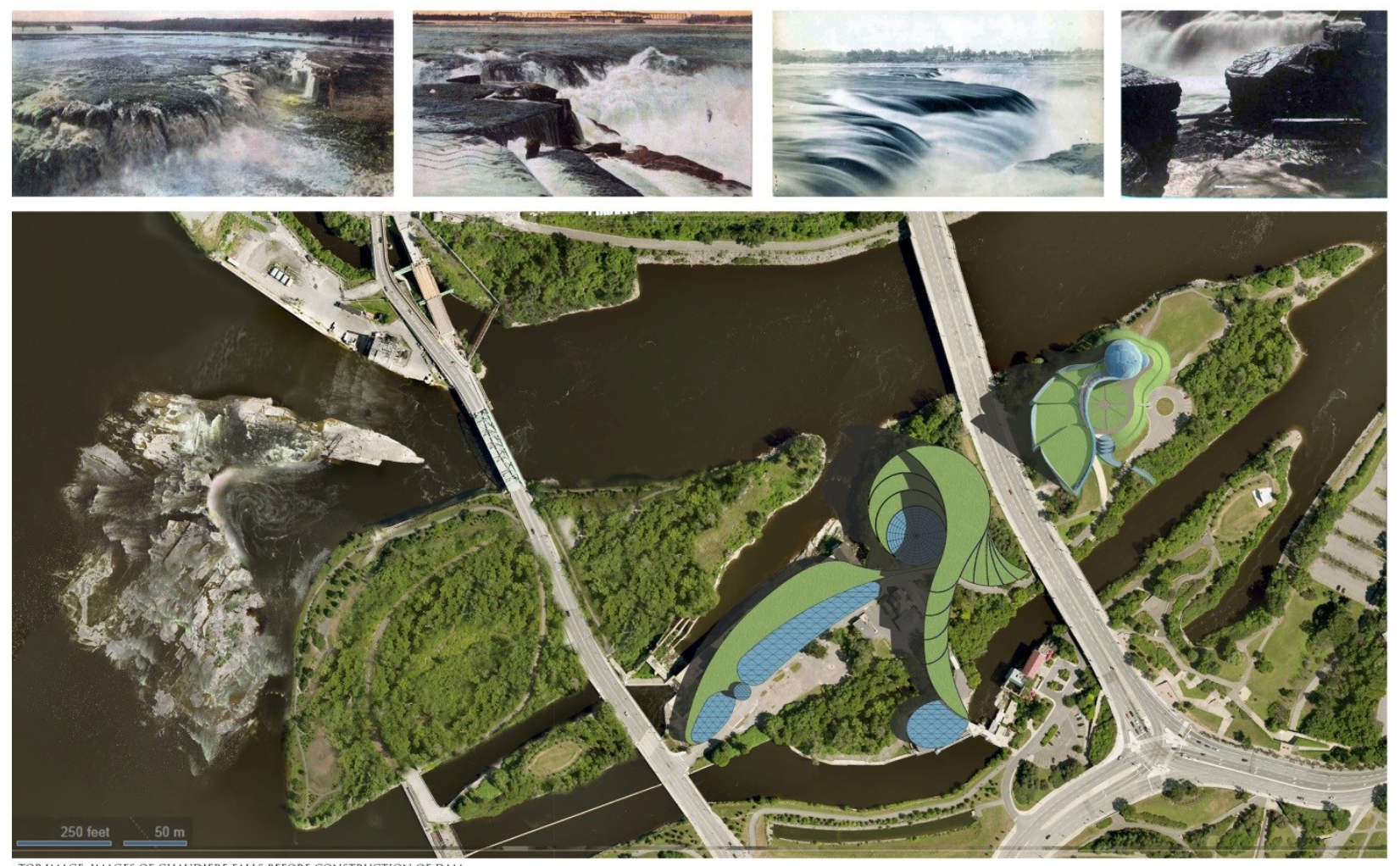

TOP IMAGE: IMAGES OF CHAUDIERE FALLS BEFORE CONSTRUCTION OF DAM

BOTTOM IMAGE: RENDERING OF RESTORED CHAUDIERE ISLAND + VICTORIA ISLAND INDIGENOUS CENTRE AND INTERNA-
TIONAL CENTRE FOR PEACE

Figure 20: Douglas Cardinal's Plan for Asinabka ${ }^{93}$

${ }^{93}$ (Circle of All Nations 2014) 


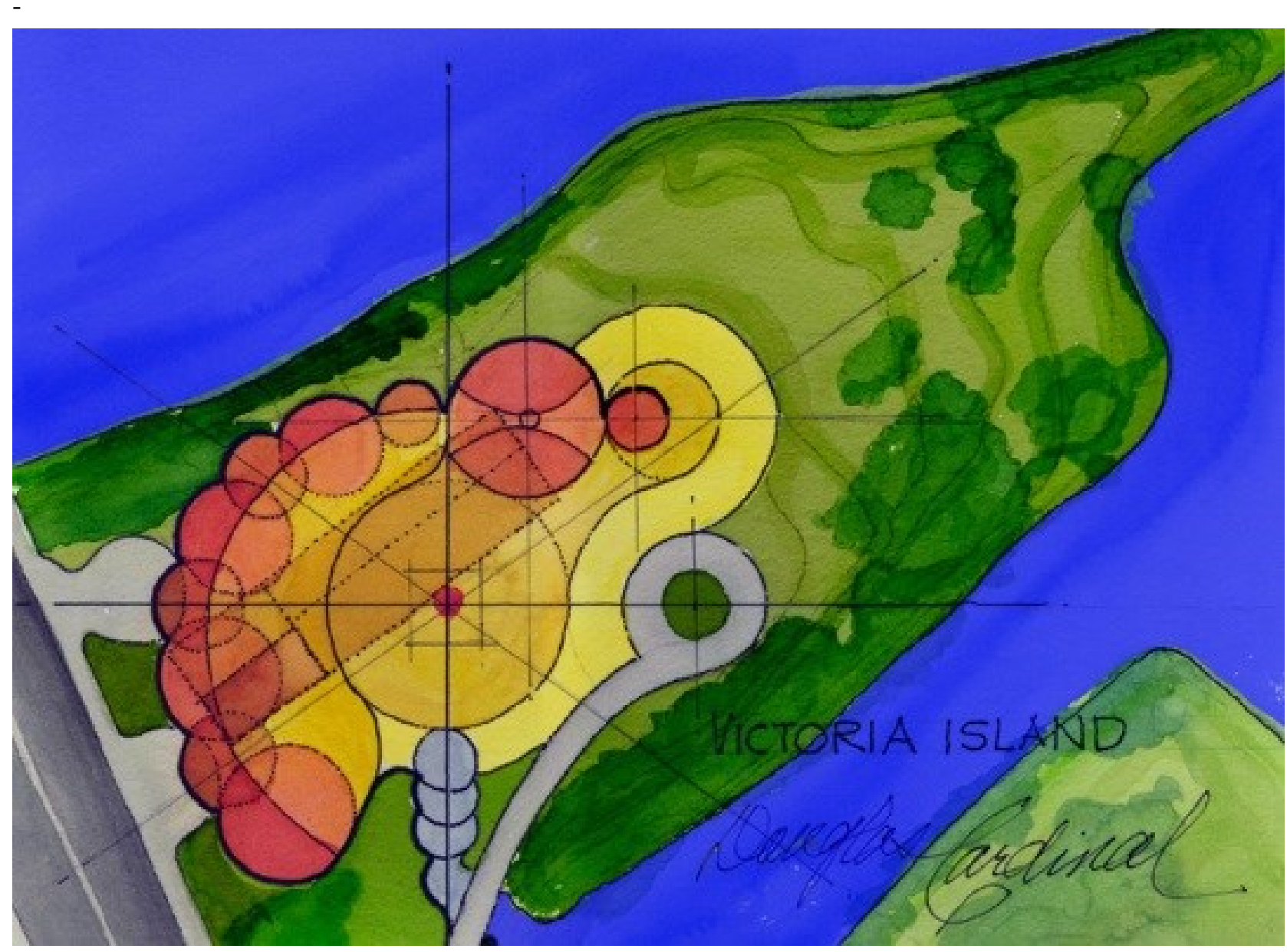

Figure 21: Concept Plan for Asinabka; Incorporation of Carbide Mill ${ }^{94}$

${ }^{94}$ (Circle of All Nations 2014) 


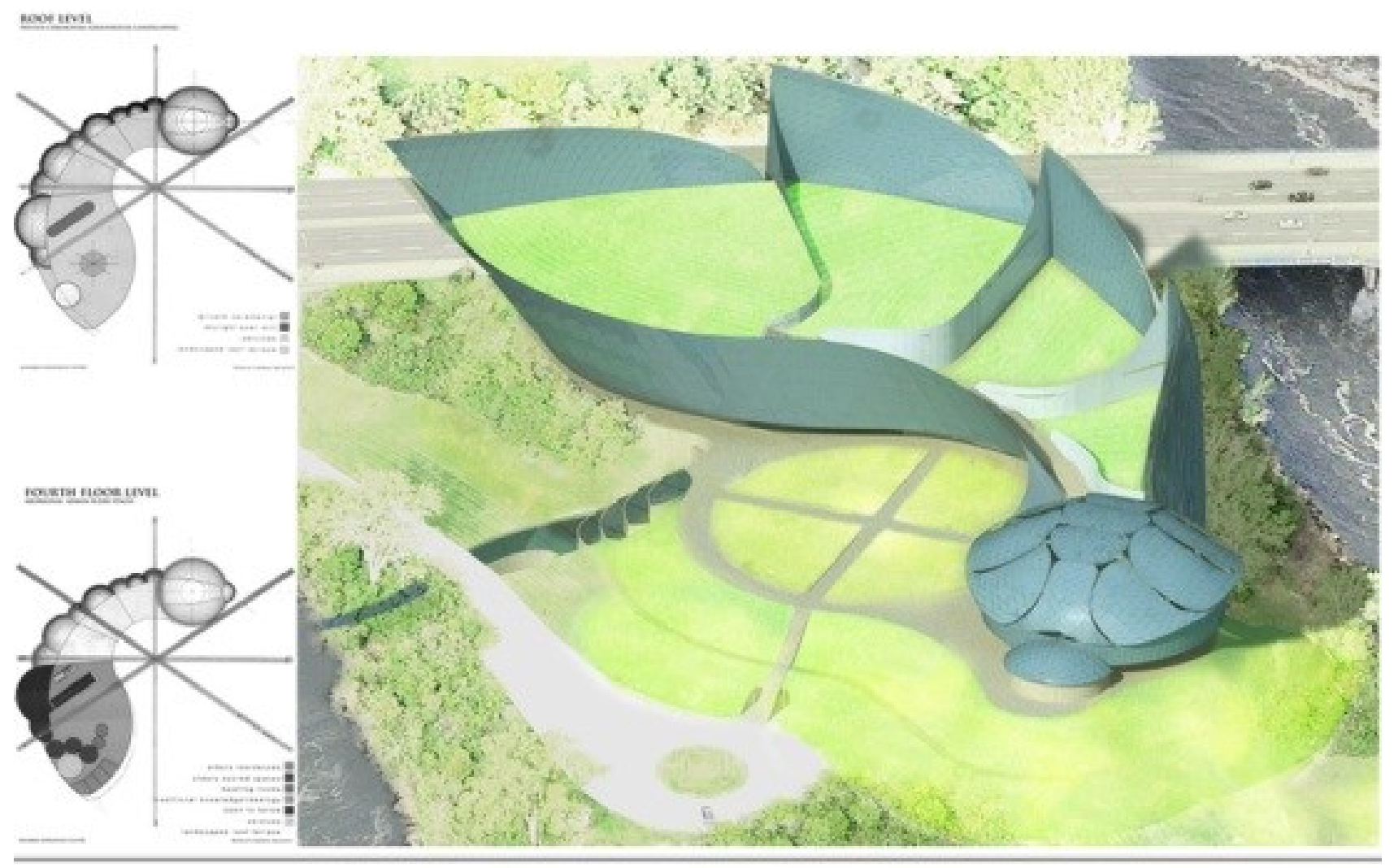

Figure 22: Renderings of Douglas Cardinal's Asinabka Peace Building ${ }^{95}$

${ }^{95}$ (Circle of All Nations 2014) 


\section{The Power to Build}

The industrial mills located on the islands in the early 1800's had the power of capital and in a way, their power was unchallenged by the government. Elder Albert Dumont believes that if the government was to go to the paper and pulp mills and request that they clean up their waste and their pollution on the land, the companies could threaten to relocate and thus the city of Ottawa would never have been as

successful economically as it was. ${ }^{96}$ Now, in our current time, there is a social movement toward the sustainability of the land and the production of jobs and high class living. All these words are seen on the Zibi Development website including phrases like "Natural Surroundings", "Award Winning Community", and "Sustainable Design", which are geared toward getting the public's vote and to draw monetary investments into the condominium properties being built on the site. ${ }^{97}$

${ }^{96}$ (Dumont 2018)

${ }^{97}$ (Windmill 2015) 


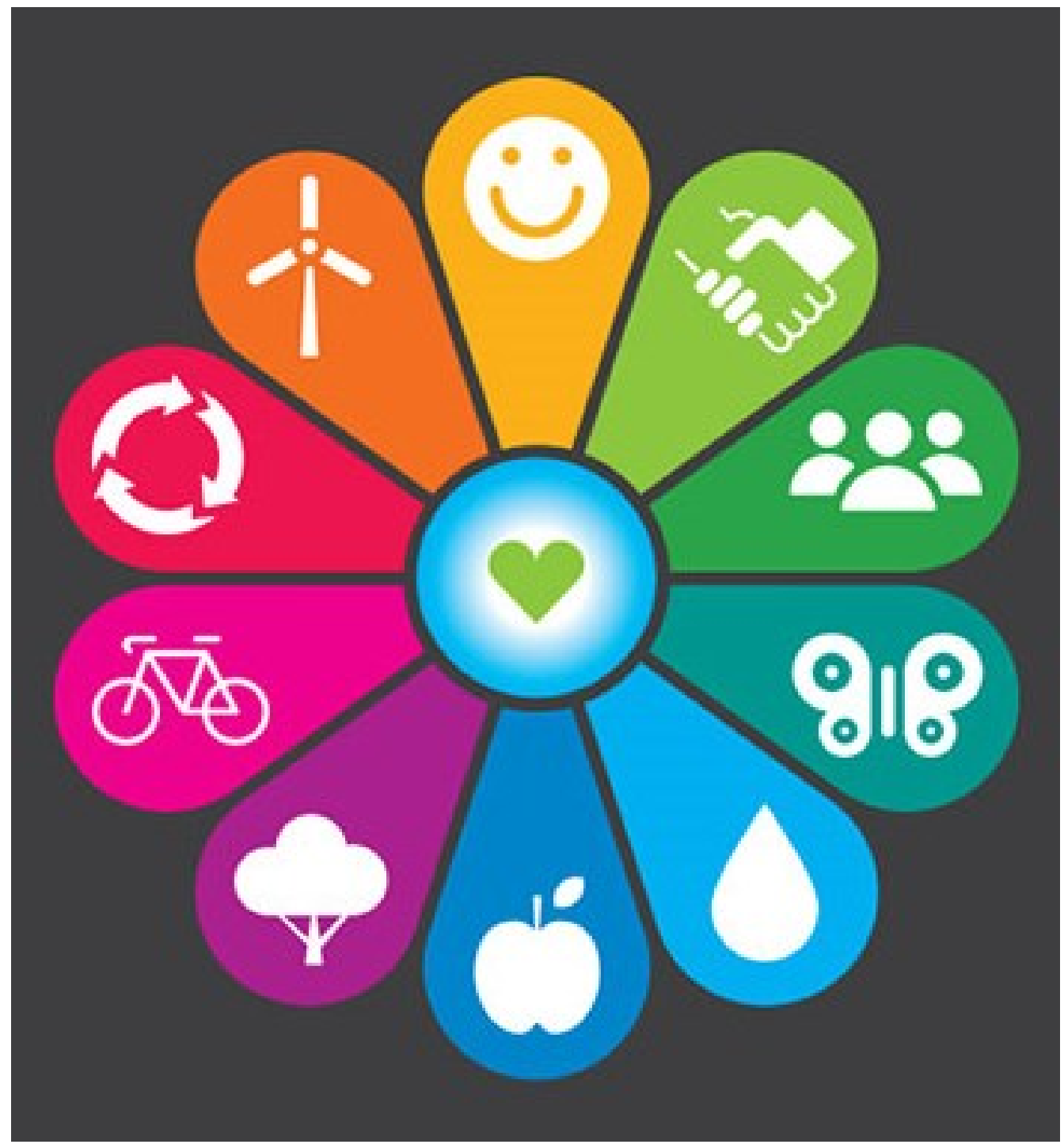

Figure 23: Diagram of Qualities of Zibi Development. ${ }^{98}$

${ }^{98}$ (Windmill 2015) 
This logo is a way to entice investors into buying their condominiums, renting out their commercial buildings, and participating in the concept of Zibi. This logo tells the story that Windmill would like to sell. The concept is that of being a "One Planet Community", focused on being zero carbon, having sustainable transport, zero waste, use of sustainable materials, Use of local and sustainable food, providing green land use and wildlife, supporting equity and local economy, use of sustainable water systems, providing culture and community, and they state they can provide health and happiness. ${ }^{99}$ However, when looking at the renderings for the Zibi development, the buildings all have the same modern aesthetic and could be located almost anywhere. The connection these proposed buildings have with the rendered site is non-existent [see Figure 24: Rendering of a Zibi Condominium].

"But the concept of promoting social identity and cohesion through design has been fading in the Euro-American culture for a very long time; indeed, it is arguable that western culture has raised estrangement itself to the status of aesthetic value. The result is that structure, program, economics, and ego now tend to dominate western design decisions, and by extension decisions made on Native lands, in a remarkable disregard for those fated to live them out." ${ }^{100}$ Page 2 in New Architecture on Indigenous Lands

\footnotetext{
99 (Windmill 2015)

100 Page 2 (Malnar and Vodvarka 2013)
} 


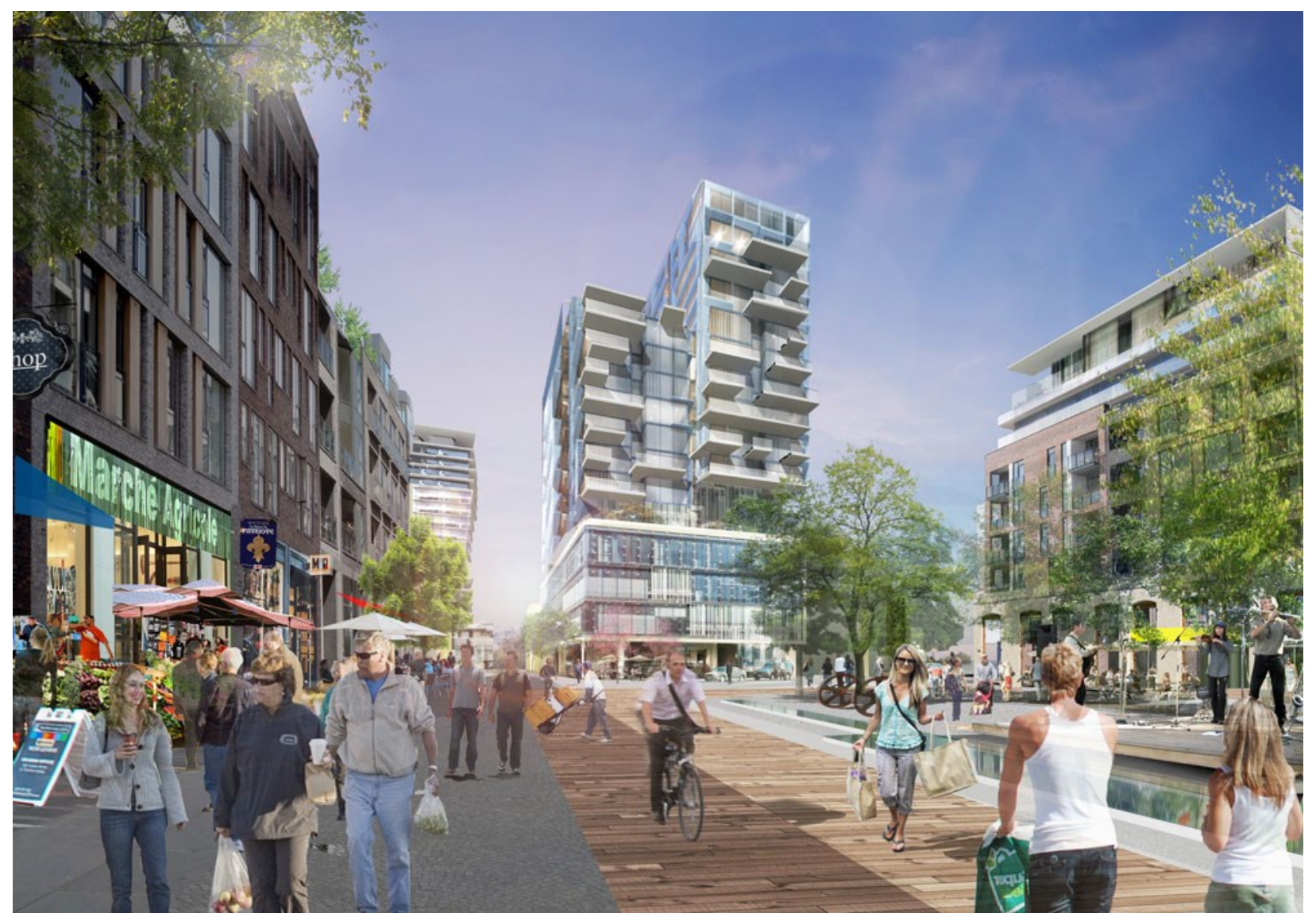

Figure 24: Rendering of a Zibi Condominium 
In figures 2 and 26, labelled "Language of the Developer" and "Universal Language of the Developer" (respectively), we see the power of words becoming a marketing tool to sell a product. While these words are powerful, they hide another message that is as much a part of their mandate, which is profit and money. Although these words seem tailored to fit this site, when the site is removed from the image, one realizes that these words could be applied to other sites instead. In fact, the language is completely disconnected from the history of the site- a new story is being superimposed on top of the existing story and in effect, is erasing the existing history. In fact, the cost of rehabilitation of the land and the industrial buildings on the island in such a short time span would require significant investment from the government, developers, and private investors. In the words of Elder Albert Dumont, "We live in a time right now where it's very difficult to be honorable because of technology and because of the power of the Almighty Dollar". The developer does not need to develop on this Algonquin sacred site; they could build their development anywhere and still use the same words to attract potential buyers. Language becomes a powerful tool that paints a picture. In figure $27^{\prime \prime}$ Language Usage on Victoria and Chaudière Islands", the language of the developer and the word usage of the native perspective are compared side to side to show how different these languages are. This disconnect in communication and language prevents the site from living up to its true potential. 


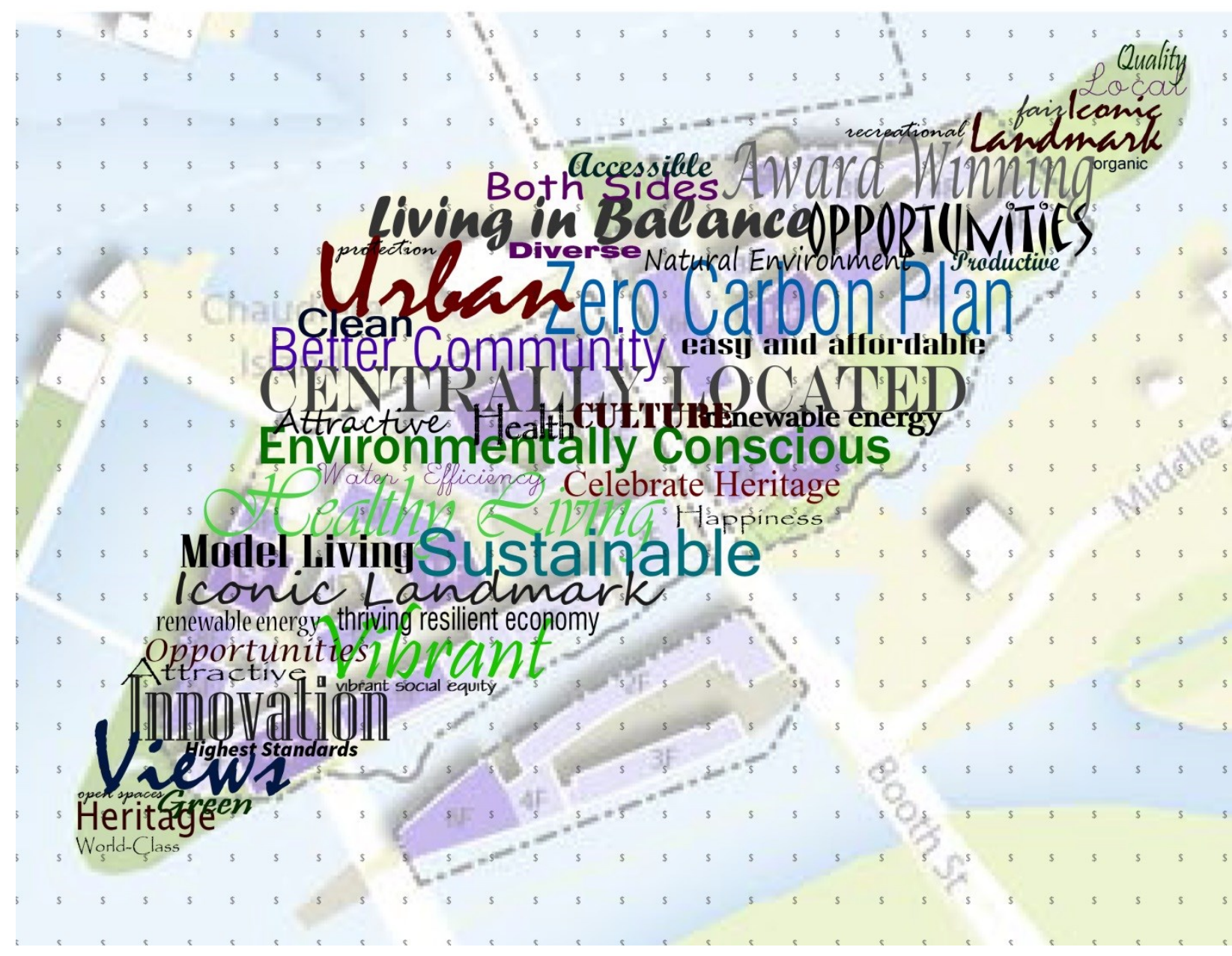

Figure 25: Language of the Developer 


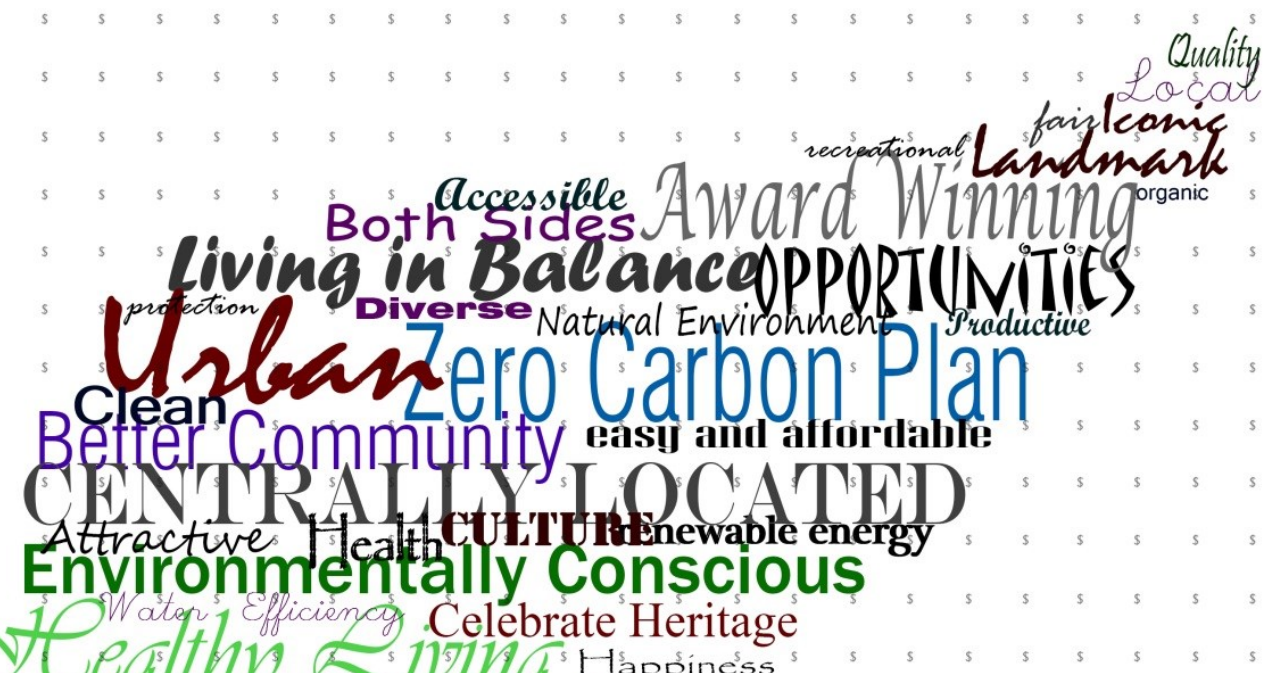

Mole living SuStainable renewable energy thriving resilient ecopomy

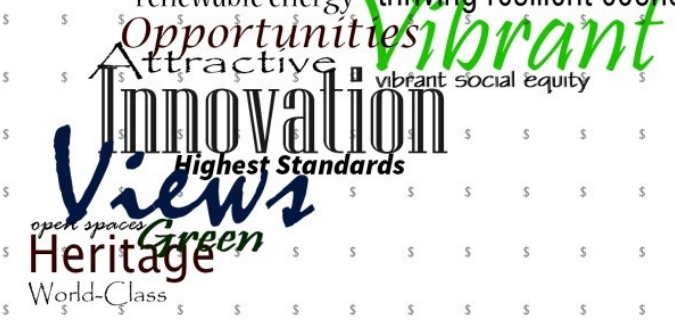

Figure 26: Universal Language of the Developer 


\section{Lanquage Usage on Victoria and Chaudière Islands}

\begin{tabular}{|c|c|c|}
\hline Zibi and Windmill Language & Nattve Language on Zlbi & Native Language on Chaudiere \\
\hline $\begin{array}{l}\text { Built for Both Sides } \\
\text { Living in Balance } \\
\text { Environmentally Conscious } \\
\text { Centrally Located } \\
\text { Celebrate Heritage } \\
\text { Connecting the Capital } \\
\text { Healthy Living } \\
\text { Sustainable and Green } \\
\text { Once-in-a-lifetime Opportunity } \\
\text { Zero Carbon Plan } \\
\text { Better Community } \\
\text { Iconic Landmark } \\
\text { Ecological Systems } \\
\text { Vibrant Waterfront } \\
\text { Complete Community } \\
\text { Incubate Innovation } \\
\text { Create and Enhance Views } \\
\text { Largest Urban Redevelopment } \\
\text { Opportunities } \\
\text { 2015 National Planning Excellence } \\
\text { Award }\end{array}$ & $\begin{array}{l}\text { Almighty Dollar } \\
\text { Right to Religious Freedom of } \\
\text { Expression } \\
\text { Unceded Algonquin Territory } \\
\text { Mockery } \\
\text { Lost } \\
\text { Broken and Dysfumctional system } \\
\text { Algonquin's should have the vote } \\
\text { Our Territory } \\
\text { Short Sighted } \\
\text { Condo or Sacred Site Justin Trudeau? }\end{array}$ & $\begin{array}{l}\text { Akikodijwan } \\
\text { Sacred Site } \\
\text { The Capital of the Anishinaabe } \\
\text { People } \\
\text { Gathering Place } \\
\text { Rest } \\
\text { Healing } \\
\text { Spiritual Power } \\
\text { Meditation } \\
\text { Rejuvenation } \\
\text { Harmony } \\
\text { Water - Life -Cleansing } \\
\text { Wellness } \\
\text { Ceremony } \\
\text { Multi-Ethnical }\end{array}$ \\
\hline $\begin{array}{l}\text { Native Thoughts on Industry on } \\
\text { the Chaudiere Islands } \\
\text { (not all industry) }\end{array}$ & $\begin{array}{l}\text { Language to Developers and } \\
\text { Investors } \\
\text { (that they will listen to) }\end{array}$ & $\begin{array}{l}\text { Emotional Undercurrenta } \\
\text { behind Native words }\end{array}$ \\
\hline $\begin{array}{l}\text { Pollution } \\
\text { Death } \\
\text { Endangered Species } \\
\text { Chains } \\
\text { Dishonorable } \\
\text { Disnespectful } \\
\text { Wounded } \\
\text { Colonialism } \\
\text { Federal Government Enemy } \\
\text { Almighty Dollar } \\
\text { Poison }\end{array}$ & $\begin{array}{l}\text { Flood Zones } \\
\text { Toxic Soil } \\
\text { Contaminated Groundwater } \\
\text { Poisoned River } \\
\text { Noise Pollution } \\
\text { Crowded Spaces } \\
\text { Isolation from Mainland } \\
\text { Grey/Bland Aesthetic } \\
\text { Restoration Maintenance Cost } \\
\text { Border Issues } \\
\text { Seasonal Evacuation } \\
\text { Construction Noises (Bridge and } \\
\text { dam) } \\
\text { Construction Delays } \\
\text { View Inhibitors to Falls } \\
\text { High Humidity } \\
\text { Mold Issues } \\
\text { Structural Issues from Groundwater } \\
\text { (Maintenance and lower building } \\
\text { lifespan) } \\
\text { Reduced Access to Site } \\
\text { Higher Ice Risk on Pathways } \\
\end{array}$ & $\begin{array}{l}\text { Government Trickery } \\
\text { Displacement } \\
\text { Loopholes in the System } \\
\text { Developer- Government Bribery? } \\
\text { Lack of Control } \\
\text { Power hungry } \\
\text { Passive Anger of the Peaceful } \\
\text { Mocked } \\
\text { mjustice }\end{array}$ \\
\hline
\end{tabular}

Figure 27: Language Usage 


\section{Native Disagreement of Zibi}

Windmill states that there is no need for them to request approval from the Anishinaabe peoples to construct the Zibi development on their land because they are considered a private developer. If the developer was under the direction of the federal government, the Algonquin people would have to be contacted and the work would pend on their approval of the project.

Windmill has disclosed that even though it was not required of them, they received the approval of indigenous people. However, they have not released the names of the people who agreed with the Zibi development. They do state that they have "been actively engaging with the Algonquins since the project outset in mid-2013."101

They also state that they are developing 37 acres of land and the Algonquin Territory spans over 36,000 $\mathrm{km}^{2}$. Regardless, Windmill is trying to illustrate that they are developing only a portion of the land owned by the indigenous people and they are trying to mitigate the damage that developing the sacred lands could do to their reputation. A loophole allows them to build on the site. Windmill states: "Yet despite the fact that the lands are unceded, homeowners and private developers don't have a legal obligation to consult with our First Nations when it comes to privately-held lands." They expose this legal loophole to shift the blame from themselves and onto the laws of the land. ${ }^{102}$

They further express that they have respect for the native peoples and that they "...share common values [with the late William Commanda] in terms of our respect for land and water, and for bringing our cultures together in a new partnership," and they will“...help be a catalyst for a First Nations cultural

\footnotetext{
${ }^{101}$ (Windmill 2015)

102 (Windmill 2015)
} 
centre on Victoria Island," and "look forward to our continued dialogue with the Algonquins and others on this front."103
"We take this opportunity to note the regrettable tendency to speak of Native North Americans in the aggregate, as though all these peoples had but one set of physical needs, thus requiring one set of design constructs to satisfy them. Even worse, there exists the perception that one set of intellectual and spiritual suppositions is sufficient to explain all Native motivations." ${ }^{104}$ Page 2 in New Architecture on Indigenous Lands

On their website, Windmill talks about ways they have interacted with what they refer to as the 'Algonquin leadership'. Some of their argument points found there have a hidden meaning that the public may overlook. In the following paragraphs, the meanings behind the words they use and the concealed other truth that potential investors may be unaware of-or may ignore, will be brought to light.

Firstly, the terminology of 'Algonquin leadership' in itself is deceiving. This over generalized term fails to mention the specific names, or associations, of the individuals that Windmill deems able to communicate on behalf of over 17,000 Algonquin peoples. Chartrand, an Elder of the Algonquin people says that there needs to be transparency about the identity of the elders who were asked for permission for their activities at a sacred site. ${ }^{105}$ This question was asked by Commanda-Dewache, "When they say they talked to Algonquins, did they talk to 20 ? That does not mean all of us." ${ }^{106}$ Part of the Anishinaabe and Algonquin legal system is all community based and relies on the consensus of the entire tribe before decisions are made final; therefore, even if they received permission from one Algonquin tribal group, the developer would not be able to correctly state that they have the approval of the Algonquin people.

\footnotetext{
103 (Windmill 2015)

104 Page 2 (Malnar and Vodvarka 2013)

105 (Comber 2017)

106 (Comber 2017)
} 
Another elder reminds us that developers can be manipulative. Albert Dumont said "I know that whenever they put out feelers about stuff like this, they know who will accommodate them. They know who to approach, and they consult with them. They don't consult with people like me. And that's not real consultation." ${ }^{107}$ Dr. Lynn Gehl, another representative of the Algonquin people cautions that the consultation process can be corrupted and that at times consent can be financially manufactured in favor of the developer. ${ }^{108}$

Windmill has published a "Memorandum of Understanding with the Algonquin leadership". The public is meant to view this as the cooperating of the Anishinaabe people with Windmill in the creation of Zibi and is meant to pacify any protests or active disapproval from the native populations. However, reading between the lines of the Memorandum [Figure 28], it is clear that the Anishinaabe people are not granted any power or say in the construction of Zibi, but they are invited to be investors in the project.

107 (Comber 2017)

${ }^{108}$ While Dr. Gehl does not provide proof of the corruption, she believes she has seen the effects of money being used to manufacture consent. She implies that 'following the money' will reveal who has been corrupted.

(Comber 2017) 


\begin{tabular}{|c|c|}
\hline \multicolumn{2}{|c|}{ Memorandum of Understanding with the Algonquin leadership } \\
\hline What Windmill Says ${ }^{109}$ & What Indigenous People hear Windmill saying \\
\hline $\begin{array}{l}\text { Formal recognition that the site is located within } \\
\text { traditional Algonquin Territory. }\end{array}$ & $\begin{array}{l}\text { Use of Indigenous people as a means of branding and selling } \\
\text { product/spaces. }\end{array}$ \\
\hline $\begin{array}{l}\text { Selecting a name for the site that acknowledges } \\
\text { the tremendous cultural and historical presence of } \\
\text { the First Nations in the heart of the National } \\
\text { Capital Region. }\end{array}$ & $\begin{array}{l}\text { Cultural Appropriation of Indigenous Language as a means of } \\
\text { gaining public support. }\end{array}$ \\
\hline $\begin{array}{l}\text { Working with Algonquin translators to ensure that } \\
\text { major signage onsite is tri-lingual - that is, in } \\
\text { Algonquin, French, and English (the languages of } \\
\text { the three Founding Nations). }\end{array}$ & $\begin{array}{l}\text { Mockery of the Welcoming Belt of the 1700s. This wampum } \\
\text { belt that was previously held by William Commanda is his } \\
\text { ancestors' view of the contract and it shows an Englishman } \\
\text { and a Frenchman holding hands with an aboriginal. The } \\
\text { signage is meant to symbolize the agreement between } \\
\text { French, English, and Native peoples in the creation of this } \\
\text { development. }\end{array}$ \\
\hline $\begin{array}{l}\text { Coordinating our planning efforts with the two } \\
\text { cities, the NCC and the local hydro operators to } \\
\text { establish an Algonquin cultural district and } \\
\text { presence in the area, encompassing the new } \\
\text { Pimisi LRT station, LeBreton Flats, Victoria Island, } \\
\text { Chaudière Falls, and the former Domtar lands. }\end{array}$ & $\begin{array}{l}\text { Densifying the site and removing the peaceful meditation } \\
\text { quality of the historic Chaudière falls. Giving power to the } \\
\text { NCC, local hydro operators and government to design the } \\
\text { sacred site without the overall permission of the Algonquin } \\
\text { and Anishinaabe peoples. }\end{array}$ \\
\hline $\begin{array}{l}\text { Explorations of options to allow for First Nations } \\
\text { investment in the proposed District Energy System } \\
\text { to be built on site, targeted to be one of the most } \\
\text { sustainable systems in the world. }\end{array}$ & $\begin{array}{l}\text { "explorations for options"- possibly thinking about asking } \\
\text { First Nations if they want to give Windmill money for an } \\
\text { investment in their cash-cow energy system that uses the } \\
\text { resources and land that is indigenous owned in the first } \\
\text { place. }\end{array}$ \\
\hline $\begin{array}{l}\text { The hiring of Canada's leading arts consultancy to } \\
\text { study how Algonquin arts and cultural spaces can } \\
\text { be integrated within the redevelopment. }\end{array}$ & $\begin{array}{l}\text { Displaying indigenous art throughout the development to } \\
\text { make it seem Indigenous friendly. }\end{array}$ \\
\hline $\begin{array}{l}\text { The development of youth mentorship and } \\
\text { internship programs. }\end{array}$ & $\begin{array}{l}\text { There will be European-style programs to help the youth to } \\
\text { become more assimilated into the culture. }\end{array}$ \\
\hline $\begin{array}{l}\text { The promotion of a First Nations workforce in the } \\
\text { construction and operations phases of the project. }\end{array}$ & $\begin{array}{l}\text { Paying the native people to clean up the pollution on the site } \\
\text { left by the Euro-American Industrial developers. Exposing } \\
\text { the native workers to pollutants which are extremely harmful } \\
\text { to their health }\end{array}$ \\
\hline $\begin{array}{l}\text { Support for and encouragement of First Nations } \\
\text { businesses and entrepreneurs located on site, } \\
\text { including discussions with a non-profit aboriginal } \\
\text { daycare provider. }\end{array}$ & $\begin{array}{l}\text { Wanting First Nations people to pay to rent out buildings } \\
\text { (that are on their land) for their businesses on the site to } \\
\text { make it look like 'all native people support this } \\
\text { development'. }\end{array}$ \\
\hline
\end{tabular}

Figure 28: What the Zibi Memorandum is Communicating

${ }^{109}$ Everything in the "What Windmill Says" can be found in the Memorandum located on (Windmill 2015) 


\section{Conclusion: Communicate a Message through Actions}

Architect and theorist David Ruy, in the closing remarks to the Aesthetic Activism symposium (2016), reminds the public that architecture sends a message and has a purpose. ${ }^{110}$ Ruy states that all architecture produces content and becomes an apparatus with a particular function, or is intended for a specific use; not only does it become an additive tool, but it can also take away or replace an aspect of the site by means of estrangement. ${ }^{111}$ With this understanding, the architect and city planner need to properly research the predicted affects that a building or construction would have on its proposed site, especially on a site as sacred and vital as Asinabka.

The land is a compilation of thousands of years' worth of stories. Whatever the future holds for Asinabka needs to be respectful of these stories and ensure these stories continue for the benefit of future generations and must be in consideration with how it can be used long term, over a span of over one or two generations.

\footnotetext{
"In this chain and continuum, I am but one link. The story is me, neither me nor mine. It does not really belong to me, and while I feel greatly responsible for it, I also enjoy the irresponsibility of the pleasure obtained through the process of transferring... No repetition can ever be identical, but my story carries with it their stories, their history, and our story repeats itself endlessly..." Carol Dowling ${ }^{112}$
}

Stories communicate a message; what messages are being communicated to the native land holders, the government, future historians, large corporations, and most importantly our future generations? Therefore, it's important to request those people who have the power to change the story.

\footnotetext{
${ }^{110}$ (Yale University 2016)

111 (Yale University 2016)

112 (Dowling 2014)
} 
The postcard in figure 29 is meant to be sent to people in power- the board of directors of the Windmill Development Group, the Honourable Carolyn Bennett (Minister of Crown-Indigenous Relations and Northern Affairs), Prime Minister Justin Trudeau, and UN Secretary-General António Guterres. This postcard is meant to spark interest in what is happening at Asinabka and to draw attention to the deeper and multicultural history of the land. The Carbide Mill floating above the land shows how this Western architecture, and to an extent the Zibi development, is disconnected from the land; even the federal heritage report makes no mention to its significance with the land. In taking a step back, the absurdity of adding more condominiums in place of diminishing sacred lands becomes more real. With these intentions in mind, these people in power will have no choice but to halt the Zibi development and reassess the impact the development will have on the site and the future. The Anishinabe people, the rightful caretakers and holders of the land, have a right to deciding the future of their sacred lands, to be able to protect their history, and maintain their ancestral heritage. 

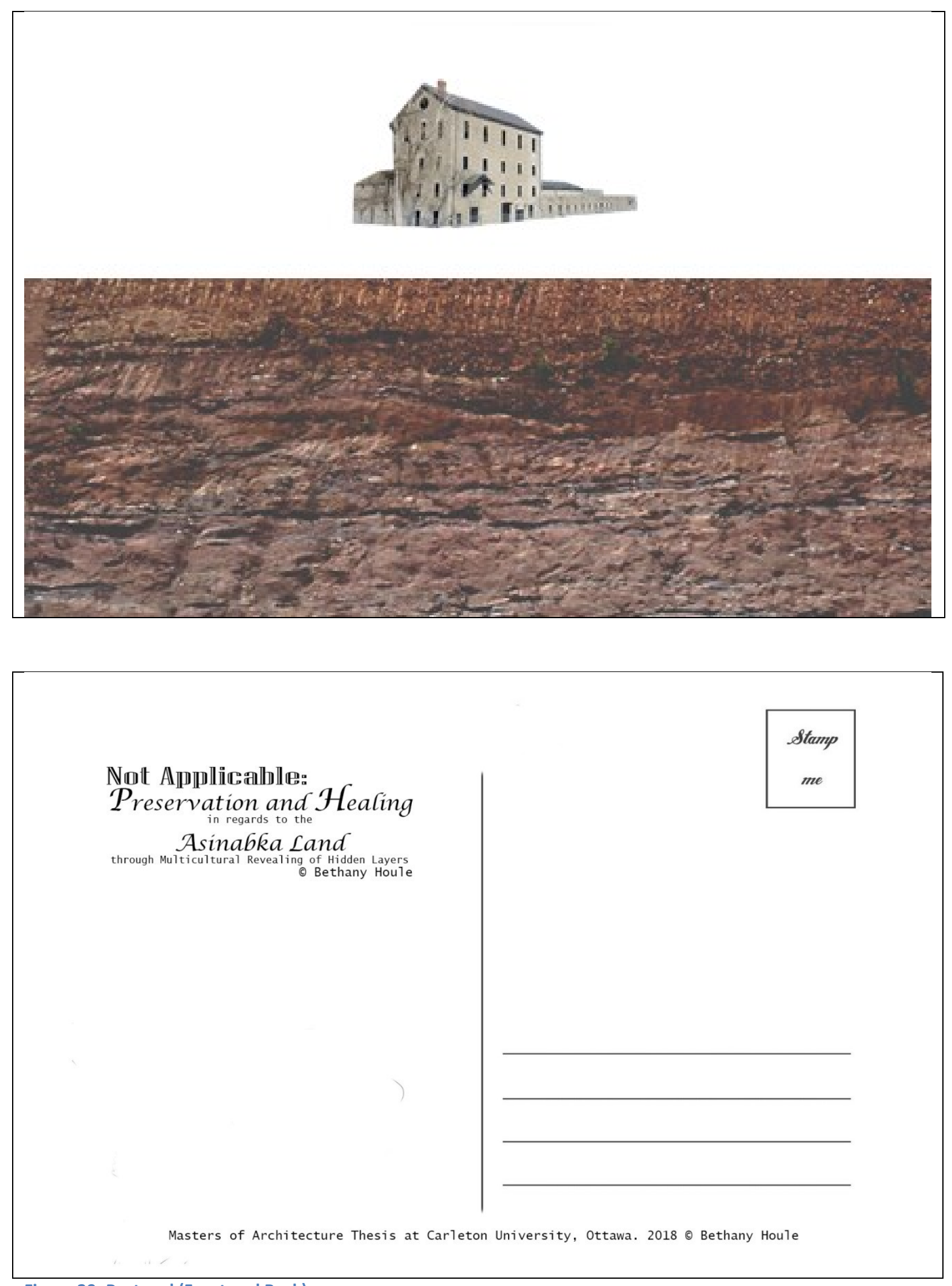

Figure 29: Postcard (Front and Back) 


\section{Recommendations}

Based on all the research concluded in this thesis, I have six recommendations for the future of the Asinabka site: make the Chaudière Falls and surrounding islands a World Heritage Site, prevent the Zibi development from being built, cleanse the land through natural remediation, return the lands to the native peoples, remove the Carbide Mill, and bring public attention to the sacredness of the Asinabka site.

In November 25, 2015, the director of The Circle of Nations, Romola Thumbadoo, put forth an extensive 53 page document to the State Parties (who determine World Heritage Site Designations). ${ }^{113}$ In this document he outlines over ten criteria to why the Chaudière site should be a World Heritage Site, which are summarized below (bold font added for emphasis):

1. Geological history and natural heritage

2. Pre-historical Paleolithic history

3. Unparalleled potential of an Accessible Chaudière Falls

4. Ecological importance, in particular to the threatened American Eel

5. Sacred importance: a meeting place from time immemorial, in the Elder's words

6. National/International historical prominence

7. Land issues and Algonquin territorial claims

8. A critical consideration - First Peoples/Canada Relations in 2014

9. Peace building and contemporary multiracial /Multicultural animation

10. Critical contemporary international Relevance and importance

Many of the issues facing the Anishinaabe people and the Asinabka site could be avoided altogether if the Asinabka site would be rightfully designated as a World Heritage Site. Lital Khaikin expresses thoughts as to why the world heritage site designation had not been accepted with over 2 years of attempts:

The area has been drafted for UNESCO World Heritage status with the continued discovery of over 6,000 year old artefacts and traces of human civilization being found along the river's coast. Despite resistance from Algonquin communities and activists, it has been enabled by the municipal and provincial Liberals through a consistent rejection of appeals, an evasive and

${ }^{113}$ (R. V. Thumbadoo 2015) 
profiteering approval process, and a perversion of private land zoning policies that causes public interests to be subsumed by those of corporate property owners. ${ }^{114}$

The second recommendation for Asinabka is to prevent the construction of the Zibi development from being built. Once the development is built, the sacred site will essentially be destroyed as it prevents public access to the site and prevents people from gathering in meditation around the site. ${ }^{115}$ The new construction designs do not properly reflect the land or the heritage of the site and lack meaning; the building renders could be located anywhere and do not uphold the character of the land or the people who hold the land. Also, the design process did not properly involve the Algonquin people so it should not be built until further and proper discussions take place. The Zibi development goes against the United Nations Declaration on the Rights of the Indigenous Peoples and does not signify the Reconciliation with the Native Population. The apology by the conservative government through previous Prime Minister Stephen Harper (2008) and the further confirmation of reconciliation by Prime Minister Trudeau is not reflected in their actions to allow Windmill to continue with construction.

"No relationship is more important to me and to Canada than the one with Indigenous Peoples," Trudeau wrote all cabinet members in their mandate letters. To which Carolyn Bennett, new minister of Indigenous and Northern Affairs, added, "That means starting out right, such that everything has been considered before a decision is taken so that you can find that win-win of 'you can develop there but not there.' "116

The third recommendation for the site is to allow for the land to cleanse itself. Natural remediation provides a lower monetary cost than removing the soil and cleansing the land through intervention. The freeing of the falls - the removal of the hydro dam from the Sacred Chaudière falls- will also aid in the natural cleaning of the land and speed up the remediation process. The land can function as an outdoor public gathering space until the soil is properly decontaminated.

\footnotetext{
${ }^{114}$ (Khaikin 2017)

115 This is the opinion of elder Albert Dumont via his interview January 2018 (Dumont 2018)

${ }^{116}$ (Switzer 2016)
} 
To follow the previous recommendation, the fourth recommendation is to return the lands to the native peoples. According to the Royal Proclamation of 1763, the Algonquin people are the rightful caretakers and holders of the Asinabka site. ${ }^{117}$ Therefore, the Anishinaabe peoples have the right to let the land heal and keep it as parkland, a green place, and a place of ceremony if they wish it and for as long as they require. ${ }^{118}$ They also have the right to determine what program occurs on the island; Elders William Commanda and architect Douglas Cardinal have been working with the Algonquin communities for over 30 years to determine the proper use and construction for the land. ${ }^{119}$ The resulting design of a Spiritual Healing Center and a Peace Center on the island will allow their voices to be heard in the capital and will allow people of all nations to grow and thrive on the islands.

The fifth recommendation would be to remove the Carbide Mill. The Mill is a representation of not only colonialism, but also of the glorification of the polluters who resided on another nation's sacred lands. By relocating the Carbide Mill, we are physically giving the lands back to the native people and in a sense 'unchaining' the land. Since the building's importance to location is not reflected in the Federal Heritage Building Report, it can be assumed that the building's heritage qualities will remain intact if it is moved to another site, such as the Byward Market, Gatineau Park, Mooney's Bay, or even Parliament Hill [Figures 30, 31, 32, and 33 respectively]. There are varying reasons why each of these locations would be appropriate places if the Carbide Mill was to be relocation (in full or in part). The Byward market would be a good option to place the carbide mill because of the industrial aesthetic would match the existing architectural landscape. The Carbide Mill could be located in Gatineau and become either a rest location or become an iconic ruinous architectural artifact. Mooney's Bay is another potential location as it is a high traffic location that can draw more public attention to the architectural heritage aspects of the Carbide Mill (a key element in the FHBRO report). Finally, the Carbide Mill can be located on

\footnotetext{
117 (Historica Canada 2015)

118 (Dumont 2018)

119 (Commanda 2010)
} 
Parliament Hill as a silent public protest against the treatment of native peoples, against the chaining of the falls, and against the construction of the Zibi development on the Chaudière Islands.

The final recommendation I suggest is to bring public attention to not only the issues at Asinabka, but also the deep-rooted cultural racism and stereotyping that occurs on a cultural level within Canadian society. The information in this thesis is meant to be used as a basis for Aesthetic Activism to be used in social media and on public platforms to draw attention to multiple stories that contribute to history- not just the mainstream story or the loudest voice. By studying the stories of Victoria Island, Chaudière Island, and the Chaudiere Falls, we understand that there are hidden multicultural layers of history.

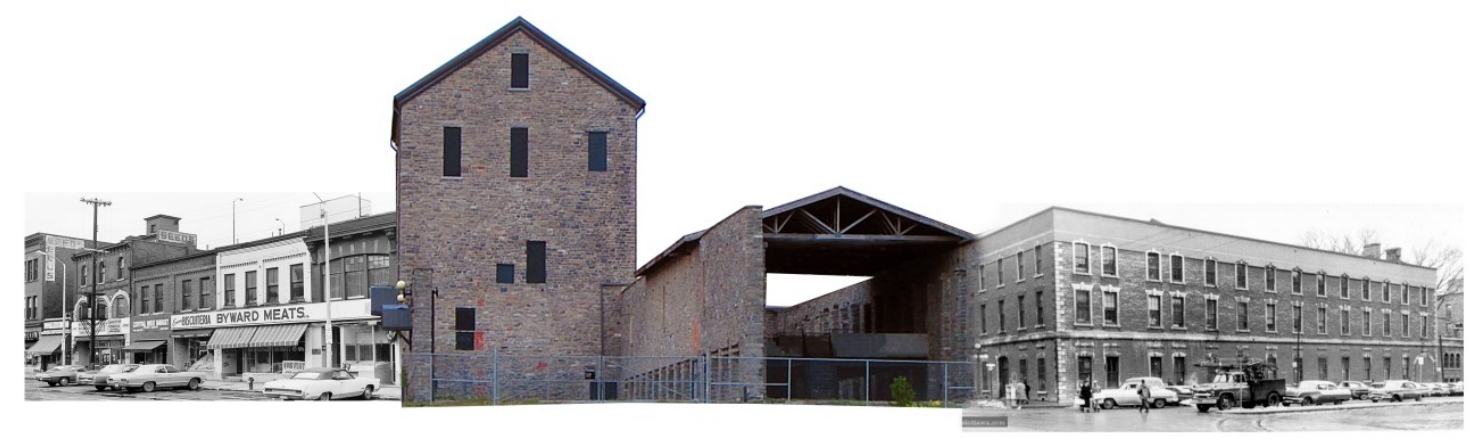

Figure 30: Carbide Mill Relocated to the Byward Market 


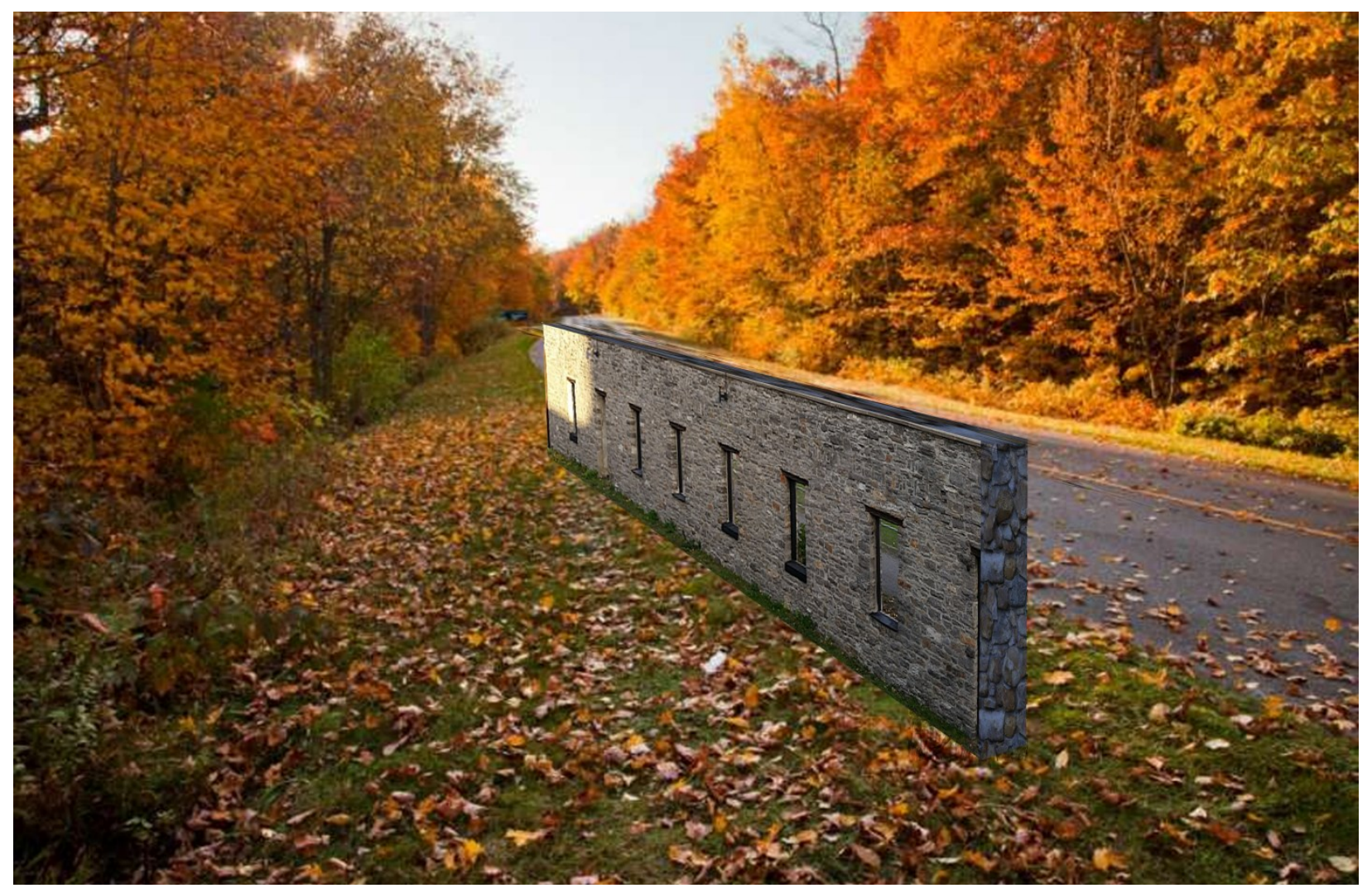

Figure 31:Carbide Mill Relocated to Gatineau Park 


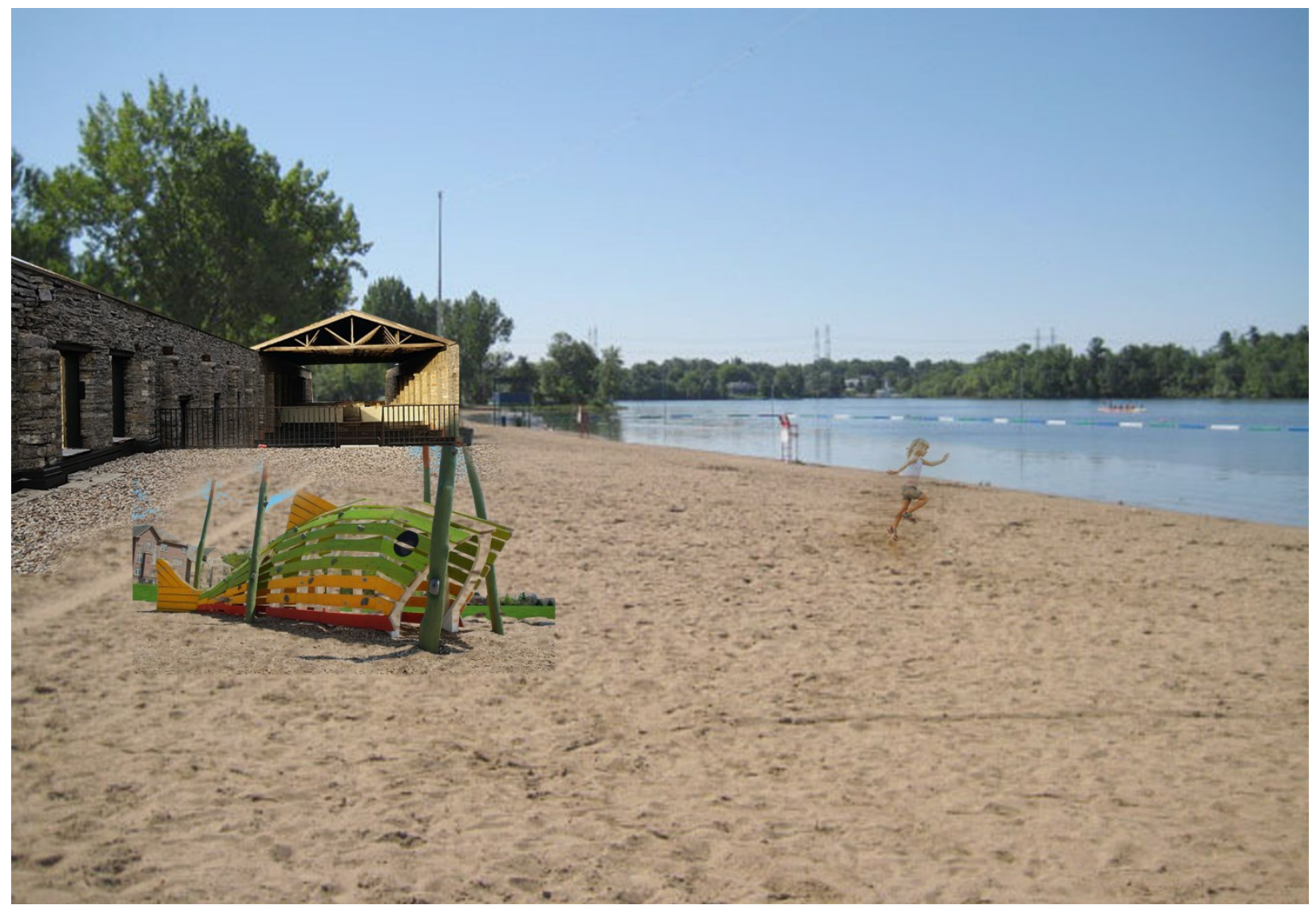

Figure 32: Carbide Mill Relocated to Mooney's Bay 


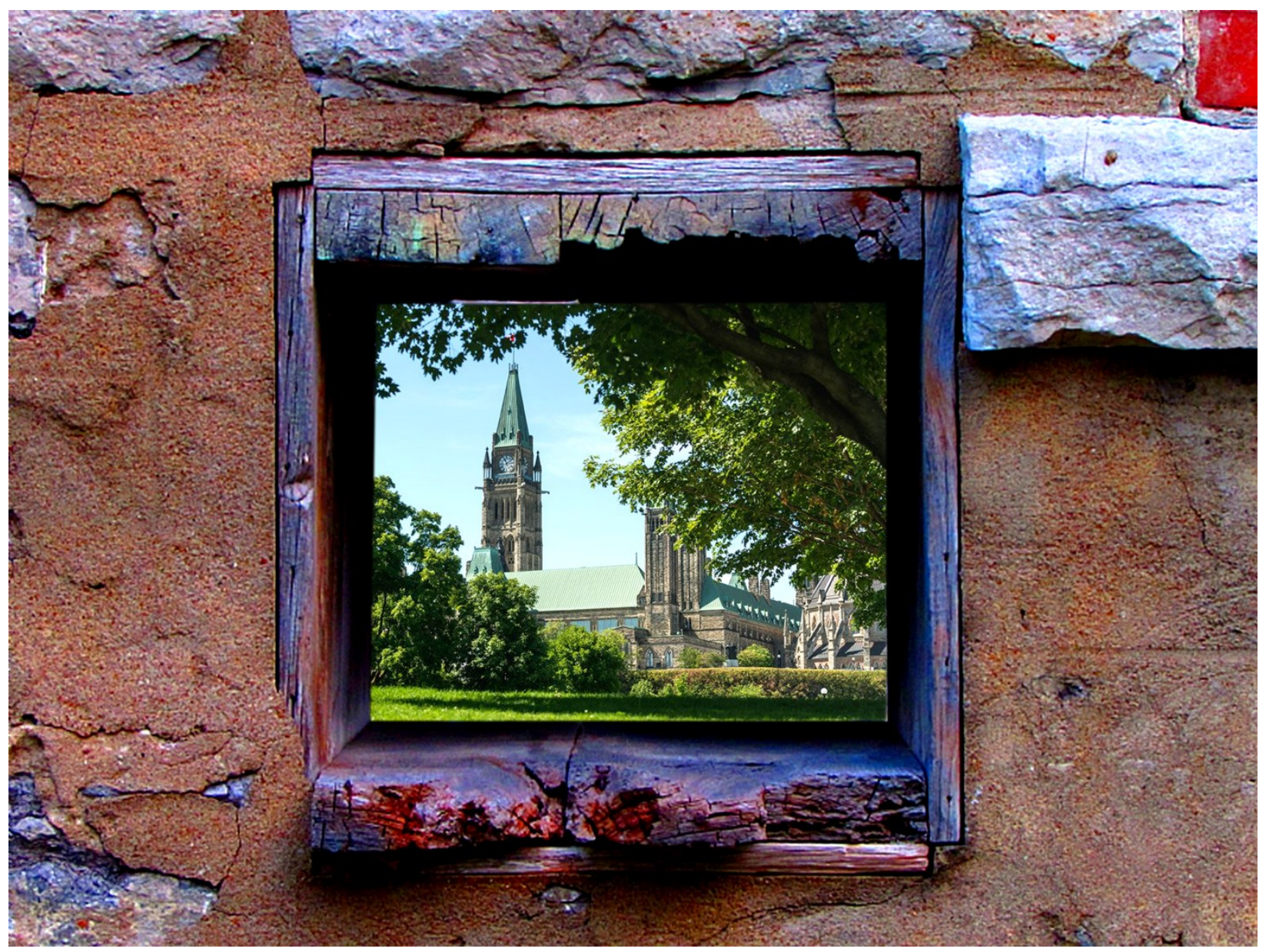

Figure 33: Carbide Mill Relocated to Parliament Hill 


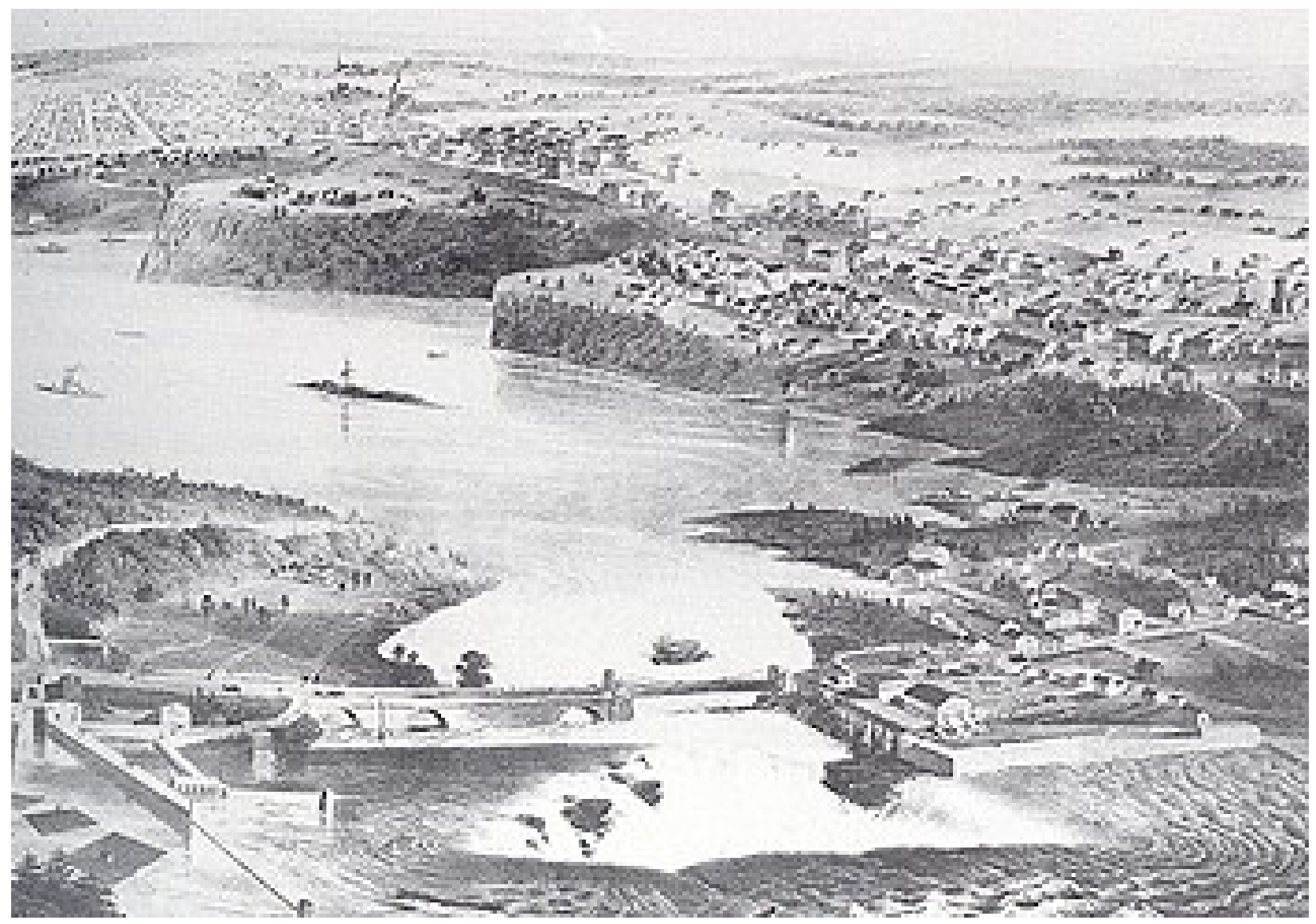

Figure 34: Historic Drawing of Chaudière Islands ${ }^{120}$

${ }^{120}$ (Urbsite 2012) 


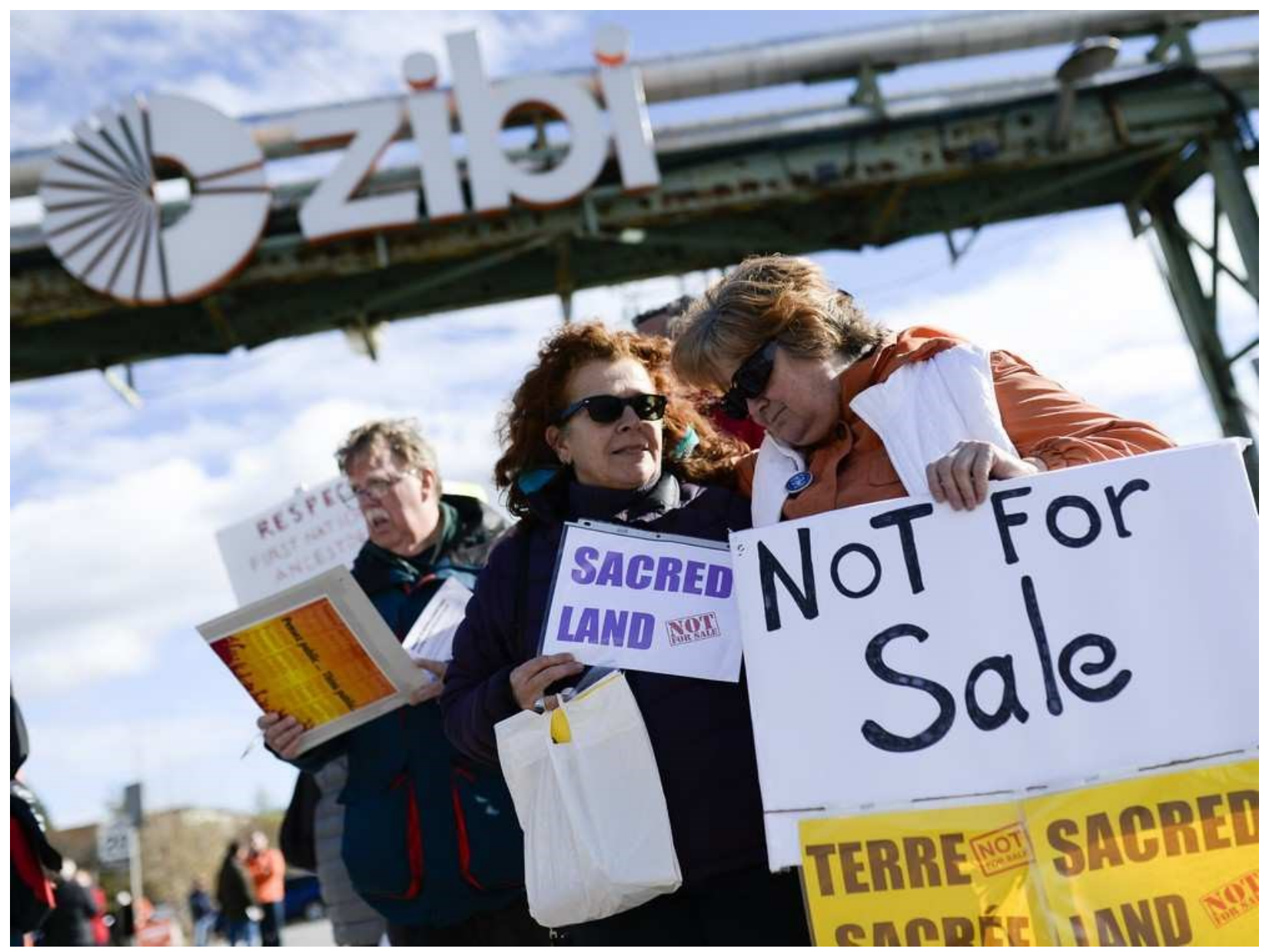

Figure 35: Protests against the Zibi Development ${ }^{121}$

${ }^{121}$ (Sibley 2015) 


\section{Appendix A: Timeline}

\section{Creation}

Creator of the Land: Kichi Manito

Animals were masters of earth $\rightarrow$ Wisakedjak

("son") gathered animal representatives in canoe for flood

Loon, Duck, Otter, until Muskrat looking for soil to remake earth $\rightarrow$ soil on turtle to make Turtle Island (Mikinak) or North America

3.8B -620M years Ago Earth lifeform glacial samples

\section{Contact}

1613: Arrival of Champlain

1640-1690: thousands die due to diseases and wars against Iroquois and Mohawks (fur trade) 1700's: Welcoming and Sharing Three Figure Wampum Belt

$17^{\text {th }}$ and $18^{\text {th }} \mathrm{C}$ : French explorers, fur traders and missionaries bring diseases (smallpox, tuberculosis, typhoid fever)

1792: Alured Clarke (governor of Quebec) allowed Lower Canada to be settled by British loyalists in US

1793: Upper Canada government had southern shore of Ottawa River surveyed for settlement 1794: Aboriginal people can travel between US \& CAN

Late $18^{\text {th }} \mathrm{C}$ : permanent settlement of Europeans in the region

\section{Industrial Age}

1801: Philomen Wright arrival

1806: Napoleon's Continental Blockade

(Europe)

1806: Philemon Wright -Ottawa River Timber

Trade (Red \& White Pine) (cutting down of

maples)

1807: Robert Randall petitioned to use hydro water

1812: Battle of 1812 (Algonquin/Native People helped keep Canada dependent of America)

1826: Bytown founded (Ottawa)

1826: commencement of Rideau Canal

1842 Neighboring building, stone flour mill, sawmill built (FHBRO statement)
1850: Bytown incorporated as a town (Ottawa) 1850's: Maniwaki, Golden Lake, and Temiscamming reserves attest to presence and right of the Algonquins from both sides of the Ottawa River 1852: First survey of Victoria Island (pg. 44Nate) Victoria Island site purchased by the crown

1854: Reciprocity Treaty (shifted to American market timber)

1855: Renamed City of Ottawa

1856: Leasing of Chaudière Island Properties to

Domtar (in perpetuity for $\$ 100 /$ year; renewable ever 20 years)

*information not revealed until 2007

1857: Ottawa decreed national Capital

1869: Lumber $\rightarrow$ Iron $\rightarrow$ Sheep as largest

exports

1876: Indian Act was passed (assimilation of native culture into Euro-Canadian culture)

1880: Bronson Office built (federal heritage) (Henry Franklin Bronson)

1894: Carbide invented by Wilson

1899: Dominion Carbide Mill explodes

1899: Wilson Carbide Mill built on Victoria

Island

1900: Great Fire of 1900

1900: Last Timber Run (decrease in demand for lumber)

1901: Opening made in western gable for fan in Carbide

1906: Booth Steam Plant built (John Rudolphus Booth)

1910: Hydroelectric dam built

1912: Booth Board Mill construction

1916: major renovation of hydroelectric dam

1936: PM Mackenzie King commissioned Greber 1939: WWII

1939: Carbide Mill used as machine shop for variety of different federal departments (Department of Public Works, Royal Canadian Air Force, etc.)

1945: WWII ended

1945: Carbide Mill vacated 


\section{Heritage Age}

1950: the Greber Plan (NCC tasked with implementing the Greber plan for erasing much of Ottawa's history, removing mills and industrial buildings while restore the falls to a more natural state)

1958: Ottawa region becomes a federal district 1958: National Capital Act passed

1959: The National Capital Act gave the NCC the power to conserve certain resources in the National Capital Region, but more importantly gave them the mandate to administer historic buildings.

1960: Natives get voting Rights

1960's: heritage preservation movement 1961: 'Our Vanishing Heritage: A Programme Proposal for Acquisition and Restoration of Historic Sites and Buildings in the National Capital Region'- carbide mill as museum 1968: American Indian Movement (AIM) created

1969: natives gain control of native education 1972: Portage Bridge cut the Victoria Island in half (preventing it from becoming a heritagethemed parkland)

1974: "Violent confrontations on Parliament Hill" (pg. 46- Nate)

1974: Native People's Caravan forcible occupied Carbide Mill (300 natives)

1974: NCC removed carbide roof from 2 storey portion

1974: NCC drilled 15 openings in eastern section carbide

1975: Fire at carbide mill (arson?)

1975: "Native People's embassy" (pg. 46-Nate) occupation by natives from Sept-Feb

1978: Fire

1985: law changed so that Indians could not be forced to give up Indian status

1980's-1990's: amendments gave bands more self-government (band membership and live on reserves)

1990: Oka Crisis in Quebec (sacred Pines) 1993: R.V. Marshall Land rights to hunt eel (Legal Battle)

\section{Green Age}

1998: NCC plans to honor sacred site 1998: Domtar purchased property for $\$ 800 \mathrm{~m}$ from George Weston Co.

1998: Domtar continues to work pulp mill

2003: Commanda consults all Algonquin communities on both sides Ottawa River. All affirm interests in the Sacred Chaudière Site 2003: Commanda requests papers that attest to NCC right to Victoria Island \& vicinity (lawyers can't provide)

2004: Native Cultural Center proposed by Douglas Cardinal

2006: All Industrial work on Chaudière Island ceased (except for buildings $540+$ 541administration) 2006: Pulp and Paper Company merged with Weyerhaeuser- deal was worth \$3.3B US 2006: Domtar start decommissioning Carbide building

2006: GENIVAR hired by Domtar to prepare Environmental Screening Report (ESR) for hydroplant 2006: Water of Life workshop for revitalization of Ottawa River watershed

2006: Commanda meets with Domtar and GENIVAR representatives

2006-2008: The Circle of All Nations struggle to prevent Domtar from upgrading the hydroelectric plant ( $9 \mathrm{MW} \rightarrow 28 \mathrm{MW}$ ) 2007: Industrial desecration ends on Site 2007: Domtar rep reveals leasing of Chaudière site 1856

2008: Commanda writes Domtar letter requesting non-contentious return of Chaudière Site (first time)

2009: Homeless in Our Homeland Campaign

2010: Domtar stops use of $540+541$ as administration buildings

2010: William Commanda's report is published 2011: most visible indigenous presence on islands. Hunger strike, Idle No More Movement, walks, daily media 2011: Eric Smith Thesis Written and Published 2013: December consultation for high-rise condo plans 
2014: Commanda writes Domtar letter requesting non-contentious return of Chaudière Site (second time)

2014: Windmill Notice of the City of Ottawa Community Consultation- second community info session=redevelop

2014: Zibi Development proposed

2016: NCC approves \$630K transformation of vacant 1880 Bronson Company (Royal Canadian Navy) Building on Victoria Island

2017: June $23^{\text {rd }}$ "Faith is Peace" Walk to free the falls

2017: Canada 150- Mìmàte (lighting the falls)

2017: Kabeshinân Minitig Pavilion

2017: Flooding of the Gatineau side of Ottawa

River (water reclaiming the island)

2018: Zibi development under construction

\section{Native Movements}

1876 Indian Act was passed (assimilation of native culture into Euro-Canadian culture)

1920 Expansion of the Native Residential Schools

1968 American Indian Movement (AIM) created

1969 Occupation of Alcatraz Island

1960 Natives get voting Rights

1970 Occupy Mount Rushmore

1990 Oka Crisis in Quebec (sacred Pines)

2016 Standing Rock Movement/Dakota

Pipeline 


\section{Appendix B: Albert Dumont Interview January 27, 2018 \\ (Given permission by and Edited by Albert Dumont) [Bold added for emphasis]}

B: I was wondering how you would propose that we clean the site? And if there are any indigenous cleansing tactics that we can use for that

A: Over a passage of time the land will always heal itself. Almost 3 years ago, I had a meeting at Chaudière Island with the owner of Windmill Developments. We were sitting on a big wooden beam and talking about the island, that it was sacred. And right where we were sitting I noticed that there were wild strawberry blossoms, right beside us- a big batch of them. I pointed this out to the owner of Windmill and he was surprised- he said he had never noticed the plants before- and he thanked me for pointing them out. To me it was a good sign that if the land/earth is so polluted, it's not that polluted that wild strawberries can't grow. When you see the blossoms, the blossoms signal that the plant is ready to produce a berry. So far as cleaning it up goes, I don't know of any techniques that can remove the poison from the soil. As far as I'm aware, the only thing we can do as human beings is ceremonymake a request of Creator to help us with it. Who knows? Maybe all the rain we've been getting- the rain is cleansing, right.

B: Is there a name for the ceremony?

A: It's just a "Cleansing Ceremony". It's not dead. We were not given ceremonies- that I know of whose purpose is for the mourning or the grieving of a river, killed by human beings. Creator didn't provide us with a ceremony to honor a dead river because Creator never expected human beings to be that stupid: to kill a river or kill a lake. And that's what we've done, we've killed lakes and we've killed rivers. The Ottawa River is a wounded river in extremely bad shape. I remember the Ottawa River in the 50's when I was a boy; we used to wade into the river knee-deep and scoop water up with our hands and drink it. You can't do that anymore, if you did you'd probably get sores in your mouth. Who knows how sick you would get?

I didn't really talk about cleansing ceremonies, it's not like there's a lot of people who know about ceremonies like that, or care to know. Because as far as religion goes, there's no religion -I don't thinkwhich has any idea of what to do when water is poisoned. But yet, religion has great power. Whether it's Christians or Muslims or Jews or whoever- they wield a lot of power because they could say to the politicians, "Don't pollute. If you pollute, we're going to vote you out." Then the politicians will have no choice but to heed their advice, otherwise they wouldn't get elected. Indigenous peoples don't have any such power. We just got the right to vote in 1960, and a lot of our people, although they have the right to vote, they went so many generations without it that they really don't appreciate it, the power of the vote. They make a mistake.

B: So can you tell me a bit about how the seventh fire prophecy can be applied to the site? Saying how if people embrace indigenous knowledge, there will be healing?

A: My knowledge of the seventh fire prophecy? It speaks about a time where human beings are at a crossroads; either they go a certain way and keep destroying the land, the water and the wind or turn onto a healing trail which takes us to a place of harmony with human beings and all the life of the environment. So it's pretty straightforward what the prophecy is about. People need to make up their minds -people could say that it's the time of the seventh fire prophecy but scientists have been saying it for a long time too. The wise people of science tell us there are only so many years left before it's too late to turn back. You know, the planet is dying. The oceans are dying. The wind is polluted. So with the 
seventh fire prophecy - if we embrace it and recognize what is going on- then it's a simple matter of making up our minds and renouncing pollution, renouncing violence and war, nuclear weaponry.

\section{B: So all things, not just physical pollutants?}

A: As far as I'm concerned, there are all kinds of pollution. Water pollution, air pollution, and there's spiritual pollution too. Indigenous spirituality is just now trying to be revived and there's lots of people who are claiming to be as one with Indigenous spirituality but they mix in hocus pocus beliefs, new age beliefs, and religious beliefs. They mix nonsense into our Indigenous spirituality and it becomes a caricature. They render it useless. We need to revive it in its worthy state. Because the government of Canada, the governments, outlawed Indigenous spirituality until almost 1960 because politicians recognized that it was powerful. Governments were hell bent on destroying us and making us disappear. This was right out of the mouths of Prime Minister MacDonald and his henchman Duncan Campbell Scott and many others.

\section{B: What are your thoughts on William Commanda's plan?}

A: His plan is really a plan of any human rights activist or any human being who cares about the survival of the people and the survival of the planet, for that matter. His dream is really the dream of anyone who cares; anyone who renounces violence and who speaks for solidarity and wellness. It's peculiar to me that people say this is a 'new' and profound dream, but isn't this the dream of everyone? A lot of people don't care. We live in a time right now where it's very difficult to be honorable because of technology and because of the power of the Almighty Dollar. It's very difficult to be honorable. Some people will say they believe themselves to be honorable, and then somebody waves a fistful of dollars in their face to get them to do something dishonorable and then they do it. You know what I mean? Because they want the money right. So to me that's why it's difficult for people to be honorable in this day and age. I don't think it was always this difficult to be honorable because if we go back in time before money was invented -see money was an invention right? (you didn't have to use money I don't think, but I don't know, maybe I'm wrong there) but whenever people traded- like I'll give you this coffee if you'll give me that donut- or something like that, you see trade was the way to go. That's how people would function, there was no money here, and there's no money in the spirit world, there isn't technology in the spirit world. So the people do actions that pollute the environment, pollute the water, and the purpose for doing so is to be connected to the Almighty Dollar.

About William Commanda's "Dream": Just ask a 10 year old or 8 year old child if they want health for the water or health for the wind. And they'll tell you the same thing, they want that too! And yet, it's just natural for a human being to embrace such a dream and vision. It's just that they never really thought about it. You're going to see the wisdom of a human being by watching and listening to your child as he/she ages- there's so much wisdom. As a grandfather, I've seen the wisdom of a human being. My little grandchildren know to be generous, they know to be sharing, but yet they know to survive. When it comes to sharing food or something, they'll think 'well now that l've shared this, don't take anymore because I need to live'. It's a natural thing.

B: On the site right now, there's the Wilson Carbide Mill and then there's the industrial buildings on the Chaudière Island Site, and a lot of them have been designated as Federal Heritage buildings. They're about 200 years old. What are your thoughts on those buildings and what would you plan for those buildings?

A: I think if they had some kind of use could be made of them (the buildings) it would be nice. You know there'd have to be some kind of structure on the island for whatever's going to be going on there 
as part of a park, that's what we want: parkland, a green place, and a place of ceremony; where all people could have their time there. Whether it's a Muslim Imam or a Jewish Rabbi or a Christian Bishop, whatever the case, they' $d$ be welcome there to speak about the greatness and the wonder and beauty of their faith or religion. And anyone who wants to go there to listen can do so anytime they wish over the passing of the year. Akikodjiwan would be about harmony with all different people of race and faith.

If there is no use for the buildings, then I would vote them off the island. Have them levelled and use the space as parkland. Circles could be laid out with stone markers or whatever where people could gather- standing in solidarity. For me, the future is not about the buildings said to be heritage. If a nuclear war occurred next week and those buildings were wiped out, who would care? They are not sacred. Those buildings are monuments of colonization. They are a statement of oppression. Spirituality gets kicked to the curb while a building is being protected. It sickens me!

B: So what are your thoughts on preservation? Like preservation of buildings and such?

A: Whenever we look at a river, we look back on a time where people were travelling with canoes. An island was often a place to pull up your canoe to the shore and sleep or cook, have some tea, regain your energy, before you continue your journey. On the River of Life, we have islands too. We have islands to rest, reenergize, to meditate. When I was leaving this morning, there was this young women sitting on the step of a building and she looked in such deep thought. I walked by her and she said 'hello' to me and I asked her if she was thinking about her sins and she said 'no! I'm just waiting on somebody'. She thought I was serious, you know, I like to joke around. But an island is where you might want to go and do that- to reflect on your life, reflect on your wrongs. So an island is special, and it's surrounded by water. Just like a baby in the womb, it's surrounded by water. It's a really profound thing in a spiritual sense, to be surrounded by water. So I think that the islands are there for a purpose and especially those islands [Chaudière and Victoria Islands] where the Jesuits recorded back four hundred years ago, along with explorers like Champlain, they recorded about the tobacco ceremonies taking place on those islands. The islands are spiritual places. If anything should be preserved for the future generations, it is the sacredness of the island

B: Was there a particular place where the ceremonies and the trading happened on the site?

A: I don't think there was trade going on there because of the fact that the islands are sacred places. Akikodjiwan wasn't a place of business. It was a place of ceremony.

B: What are your thoughts on the Zibi Development and Windmill?

A: I don't see the developer as an enemy. A developer is an animal who sees a deserted lot and he immediately makes a plan to develop it - it's the nature of the beast. I've got no quarrel with the developer. I frown on the developer's tactics -some of them are pretty vicious - they use their wealth to bring about dishonor. It's the politicians, you see, who are the real enemy. Like in this case, the federal government is the biggest enemy. The municipal politicians are very wrong, too, because they rezoned that very land. John Baird, who was a big man in Harper's Conservatives, worked it all out. But I'm sure he must have been contacted by the developer and who knows what went on because John Baird just didn't say one day 'ya, sure, I'm ok with destroying a sacred site'. I'm sure something happened, but l'll leave it up to people's imaginations to figure it out. The provincial politicians, they're all OK with the developing of a sacred site. Once there are condos there, it's forever lost- the sacred site. And that's that. It proves that this thing of respecting people's right to freedom of religious expression enshrined in the constitution is just smoke and mirrors. It's a mockery. It's a song and dance. It's like 
Canada telling a Christian 'we grant you the right of freedom of religious expression, but we deny you the right to go into your own church. We, the government have that kind of power and we're stopping you from going into your church. But you can still be a Christian'. That's what politicians are doing by blocking us from entering our sacred place. They sign the death certificate for a holy place. It's bigotry at its worst! It's like someone who would dare to make a move to destroy the grandest cathedral in Ottawa. People would rise up and say 'no way are you going to do that!' The plan to do so would soon stop. But because it's Indigenous spirituality, who cares? It just proves how Canadians really feel about Indigenous spirituality. People don't stand up to defend MY right to freedom of religious expression. The United Nations has said that I have a right to my own faith, that it's in the constitution, but in reality, no. The politicians stop us. I guess it's accepted that, as long as somebody's making money, it's OK to pulverize Indigenous faith and spirituality. It's like a businessman who would poison a river or poison an ocean and somebody goes up to them and says to the businessman 'the ocean is dying' and he responds 'well did anybody make any money because of it?'... 'Oh ya! Lots of money was made'. And they say, 'well, that's what happens sometimes.' Death may well occur but as long as somebody made money, it's all well and good. I had this thought one day and I imagined a family sitting down for their supper and there's a knock on the door. The man/women of the house answers the door and there's a stranger there who says 'we're here to inform you that the maple tree has been stricken with some kind of virus so in a year's time there's not going to be a single maple tree left alive.' And the homeowner says to the stranger 'are my taxes going to go up because of this?' The stranger replies 'no, taxes aren't going to go up at all. I'm just here to inform you that the maple trees will be forever lost.' The homeowner says 'well thank you very much for the information', closes the door and goes back to enjoying their meal- not caring at all. In their mind they think there are still going to be poplar trees, and birch trees, and all the other trees, and too bad the maple will be gone but we can get along without them- even though the maple leaf is on our flag. Even though the maple tree is a great teacher, they don't care. And that's what the Almighty Dollar does to the minds of a lot of people.

B: Research shows that the reason William Commanda's plan didn't go through was due to lack of leverage money needed to initiate the federal government involvement in the funding of the project. Do you think there's another reason for why his plan didn't go through?

A: See the politicians are very short-sighted, because if those islands were parkland, and with the falls there, imagine the tourist attraction it would be. Just like tourists go to the Niagara Falls, tourists would come here for the same reason: to go to the park, to stand at the edges of the waterway railing and to have orators eloquently tell them the history of the place- the sacredness of it. But they [the politicians] don't see it - they fail- because all they see is the dollar. They think of the millions of dollars that the developer will spend there. And that's what they see, they focus on their tunnel vision, they see the investment of the developer and that's what they want; to be able to say while they were serving as a politician that the economy went up or whatever. Such is their wisdom. But what they don't want people to know is that somebody's rights of freedom of religious expression were destroyed during their watch. They're not going to pay attention to William Commanda anymore than they'd listen to the wisdom of 8 year old or 10 year old children who want the waters to be healthy. See, a child will say these things. The politicians wouldn't listen to William Commanda; William just wasn't rich enough to get their attention.

\section{B: What do you think of the Federal Heritage Report for the Carbide Mill?}

A: Whether it was this company or the lumber barons, they were all big polluters. After they did their pollution and made their wealth, away they went. They left their poison for other people to deal with. At the height of the timber industry, there was 60 feet of sawdust at the bottom of the Ottawa River. 
But the politicians didn't care because the lumber barons had more power than the prime minister. Because if the politicians had said 'stop the pollution', the lumber barons would have said back to them 'we'll take our business somewhere else if you don't shut up'.

But these companies that pollute... who would want a relic or an artifact of someone that has polluted so much? I don't get it. These were the biggest polluters. Like I said, they live for protecting the Almighty Dollar. To me, if there are heritage buildings there, as an Indigenous human being, I will never honor anyone or anything which brought pollution and became wealthy from poisoning Algonquin land and water. They did what they did, they didn't have any respect for, nor did they honor the Indigenous people here, so I condemn them.

B: with my project, I am working toward having these buildings undesignated; I don't believe they properly express the full history of the site or properly recognize Indigenous people or their stewardship of the land. I would like to remove the buildings and in that way, give back the land to the Algonquin people.

A: Yes that's right. Stone, mortar, poison, the Almighty Dollar - who in their right mind would honor these things? It's almost like asking us to honor Residential Schools. It's senseless.

B: You said putting condos on the site would make it lose its sacredness. Why is that?

A: Akikodjiwan will always be sacred regardless if condos are present or not. What will be lost to the people is access to our grandest holy place. The condos, the buildings will be there and there will be no space to make a circle. Human beings are imperfect; that space was for a human being to go and learn about becoming a better human being.

It's a dysfunctional world. You know whenever we think about the 'systems' that we live under, the education system, the welfare system, the justice system... all of the systems are dysfunctional. All of them are broken. We need the sacred site; so that we could go there and find some kind of balance for our hearts, for our spiritual and emotional wellbeing. We need those places out there.

B: So is your plan to have the gathering space, green space, and ceremonial space for Chaudière Island or Victoria Island as well?

A: For all those islands, Chaudière Islands, Albert Island, and Victoria Island. You see, those islands are in the midst of water and the power of water- the energy- the spirit of that place. This might be important for you to write...

I had severe addiction issues; I'm celebrating 30 years of sobriety in April. There was a small river, a secluded river, where falls and rapids mixed, that I went to, to find the strength to stay strong in my sobriety. And if those small falls on a secluded river could fix somebody like me who had a severe addiction, then what could a grand place like Akikodjiwan do for the wellness of all people? For me, that's the way it is. And yet they say 'no, we're going to build condos.' It's mind boggling; spiritually mind boggling, and emotionally draining.

B: I read your blog about Akikodjiwan...

A: If you want to quote from the blogs, you can do that too.

B: What do you think about William Commanda's report, his idea of adding a cultural center and an international gathering space as buildings on the site? 
A: I think we need to cross that bridge when we get to it. I think first of all we need to stop the plan for condos then let's look at what's left there, if that makes sense. I'm against the Windmill development. I'm the kind of person nobody is going to lead me by the nose. I'm going to think about it and see the sense of it or the nonsense of it and then I'll make up my mind on what to support. And everyone should be like that. We need time to think it over and process it properly then make the decision whether we're going to support that kind of a structure there or whatever they're talking about. I think that's the goal and I'd like to see what the sense is of building the structure right there as opposed to somewhere else nearby. You're going to want to write this too...

"Let them build condos at the old American Embassy and leave our sacred site alone! The developer can have it and give us back the islands and Akikodjiwan again."

The people who put forward a plan for destroying Akikodjiwan are from a colonizer bloodline. The only people who l'd say are entitled to a vote though [on the island's future] are the Algonquins. Because it's our territory. It's not Métis territory, it's not Inuit territory, it's not Mohawk territory, or anybody else's territory, it's us, the Algonquins, we will decide. My idea for the site is to keep it green space, parkland, and sacred space.

B: is there anything you would like to elaborate on?

A: Just that I'm very concerned for the health and wellbeing of future generations. After we're long gone, after I've lived my life and you've lived yours, your children, who's going to be next? Will there be a next generation? And how healthy are they going to be?

One time I had this thought, I imagined a world in the future where human beings lived in big domes and the domes are five miles long and five hundred feet high. Air is being filtered so you could live in these domes. And these domes are connected by these tunnels, and that was how human beings could live because outside the domes was poison and emptiness, no bird or animals, everything gone because of poison: all the food sources and plants and everything. I wouldn't want to live like that. A human being was not meant to live in a dome. But if we keep it up, something's going to give. Something that's alive can only take so much torture before it passes away and nothing's left. Politicians and people need to think about stuff like that. Do they want their bloodline to stop? I want my bloodline to continue. I want my bloodline to still be here $\mathbf{5 0 0}$ years from now. Not only do I want them to still be here, I want them to be healthy. Like I said, there are better places to put the condos that won't endanger the site. We become better human beings through the wellness of water.

What better way to prove that reconciliation can occur? Indigenous spirituality is on the rebound. It was illegal in 1960, when we were not in a position of power. That's the way the world goes; who has the numbers? Who has the money? To persuade the politicians and push them to do what's right; because the politicians, most of them anyways, go where the money is. Where are the honorable members? I haven't met very many. Maybe I should light a candle and go looking for one. 'I'm looking for an honorable politician, up on Parliament Hill with my candle,' or l'll try a flashlight [you're going to have to look very closely!]. I don't know, maybe he's under a rock, 'you under there? No he's not honorable.'

B: do you have any good sources that I could use for my research and to dig deeper?

A: The book 'the Acre of Time', yes. Phil Jenkins, you can order it from Phil Jenkins. In February, we're going to be doing something on Roger's TV, just email me and remind me to send you that.

$* * *$ End of Interview**** 


\section{Bibliography}

Baillie, Britt, and Wendy Pullan. Locating urban conflicts: ethnicity, nationalism and the everyday. Cambridge: Palgrave Macmillan, 2013.

Bataille, Gretchen M., and Charles L. P. Silet. The Pretend Indians: Images of Native Americans in the Movies. lowa: Ames : lowa State University Press, 1980.

Bureau D'Evaluation des Edifices Federaux a Valeur Patrimoniale. Usine de Carbide, Ile Victoria, Ottawa, Ontario. Federal Heritage Building Report, Ottawa: Marc de Caraffe, I.B.H.C., 1983.

Campbell, Jackie. Phytoremediation of contaminates sites. July 7, 2010. https://www.siskinds.com/envirolaw/phytoremediation-contaminated-sites/ (accessed April 2018).

Cardinal, Douglas. When condos speak louder than words, and the battle for Chaudière falls. August 19, 2016. http://ottawacitizen.com/news/local-news/douglas-cardinal-when-condos-speak-louderthan-words-and-the-battle-for-chaudiere-falls (accessed April 2018).

CBC News. Ottawa committee approves rezoning on sacred aboriginal site. October 2, 2014. http://www.cbc.ca/news/canada/ottawa/ottawa-committee-approves-rezoning-on-sacredaboriginal-site-1.2785746 (accessed January 2018).

Circle of All Nations. CIRCLE OF ALL NATIONS MESSAGE REGARDING WILLIAM COMMANDA'S LEGACY VISION FOR THE SACRED CHAUDIÈRE SITE FROM ROMOLA V. THUMBADOO. Open Letter, Ottawa: CIRCLE OF ALL NATIONS, 2014.

Comber, Julie. "Spotlight Hiding a Dam Shame: Controversial Mìnàte Show Continues at Akikodjiwan (Chaudière Falls)." The Media Co-op, October 13, 2017.

Commanda, William. A REPORT ON THE VISION FOR THE ASINABKA NATIONAL INDIGENOUS CENTRE. February 14, 2010. http://ottawa.ca/calendar/ottawa/citycouncil/occ/2010/11-19/cpsc/02\%20report\%20on\%20the\%20vision\%20for\%20the\%20Askiabka.htm (accessed March 21, 2018).

Douglas Cardinal Architect Inc. "Victoria Island Indigenous Centre and International Centre for Peace." Asinabka Cultural Center. Ottawa: Douglas Cardinal Architect Inc., 2014.

Dowling, Carol. Finding Your Own Kind or My Grandmother's Mother's Mother - the Exhibit! July 3, 2014. https://www.tandfonline.com/doi/abs/10.1080/13200968.2007.10854375?journalCode=rfem2 0 (accessed April 2018). 
DST Consulting Engineers Inc. Phase Two Environmental Site Assessment Update for Domtar Lands Redevelopment of Chaudière and Albert Islands. Site Assessment Update, Ottawa: DST Consulting Engineers Inc., 2014.

Dumont, Albert, interview by Bethany Houle. Interview with Elder Albert Dumont on Chaudiere Falls and Surrounding Islands (January 28, 2018).

EPAC. 4 Different Types of Remediation, and Why They Are Important. October 21, 2017. http://www.epacinc.com/types-remediation-important/ (accessed April 2018).

EquitableEducation. Architect Douglas Cardinal on the Chaudière Falls \& Islands, and the Windmill condominiums plans. September 30, 2014. https://www.youtube.com/watch?v=UeFqbRBU5mk (accessed February 2018).

Escobar, Arturo. Territories of Difference: place, movements, life, redes. Durham and London: Duke University Press, 2008.

Firsthand. From time immemorial - Pre contact life in Kanehsatà:ke. September 23, 2017. http://www.cbc.ca/firsthand/features/oka-timeline-an-unresolved-land-claim-hundreds-ofyears-in-the-making (accessed March 2018).

Fontaine, Tim. "Canada officially adopts UN declaration on rights of Indigenous Peoples." CBC News, 10 May, 2016.

Hall, Edward. Beyond Culture. New York: Anchor Press, 1976.

Historica Canada. Royal Proclamation of 1763. July 02, 2015.

http://www.thecanadianencyclopedia.ca/en/article/royal-proclamation-of-1763/ (accessed March 2018).

Spudwrench - Kahnawake Man. Directed by Alanis Obomsawin. Performed by Randy Horne. 1997.

Indigenous and Northern Affairs Canada. Frequently Asked Questions. April 04, 2011. https://www.aadnc-aandc.gc.ca/eng/1303147522487/1303147669999 (accessed March 2018).

-. The Day of Apology. May 27, 2015. https://www.aadncaandc.gc.ca/eng/1100100015657/1100100015675 (accessed April 2018).

Indigenous Corporate Training Inc. First Nations Sacred Sites. 2018. https://www.ictinc.ca/blog/firstnation-sacred-sites (accessed March 2018).

Jensen, Nathan. "Constructed Histories Storytelling and the Practices of Archtiectural Conservation." Constructed Histories Storytelling and the Practices of Archtiectural Conservation. Ottawa: Carleton University Architecture Faculty of Graduate Studies and Research, 2009.

Kelly, John M.H., interview by Allan Ryan and Bethany M. Houle. Haida Chief (January 2017). 
Khaikin, Lital. To Justify Land: Occupation, Power, and Real Estate Motives at Asinabka. October 31, 2017. http://www.mediacoop.ca/story/justify-land-occupation-power-and-real-estatemoti/36622 (accessed April 2018).

Lavell-Harvard, D. Memee, and Jeannette Corbiere Lavell. "Until Our Hearts Are On the Ground" Aboriginal Mothering, Oppression, Resistance and Rebirth. Toronto: Demeter Press , 2006.

Malnar, Joy Monice, and Frank Vodvarka. New Architecture on Indigenous Lands. Minneapolis London: University of Minnesota Press, 2013.

Kanehsatake 270 Years of Resistance. Directed by Alanis Obomsawin. 1993.

My Name Is Kahentiiosta. Directed by Alanis Obomsawin. 1995.

Payne, Elizabeth. Windmill wants up to $\$ 62$ million from the city to clean up and redevelop Zibi site. December 15, 2016. http://ottawacitizen.com/news/local-news/windmill-wants-up-to-62million-from-the-city-to-clean-up-and-redevelop-zibi-site (accessed February 2018).

Pearson, Matthew. Hydro Ottawa to buy Quebec's remaining share of Chaudière Falls power. June 20, 2016. http://ottawacitizen.com/news/local-news/hydro-ottawa-to-buy-quebecs-remainingshare-of-chaudiere-falls-power (accessed April 2018).

Pomeroy Otis, Charles. Voyages of Samuel de ChamplainTranslated from the French. 2013. http://www.canadahistory.com/sections/documents/colonial/voyageschamplainii.htm (accessed April 2018).

Sequeira, Jillian. Stolen Identities: The Repatriation of Indigenous Artifacts. August 22, 2016. https://lawstreetmedia.com/issues/entertainment-and-culture/stolen-identities-repatriationindigenous-artifacts/ (accessed April 2018).

Sibley, Robert. Billion-dollar Zibi project caught in aboriginal politics, says developer. December 9, 2015. http://ottawacitizen.com/news/local-news/billion-dollar-zibi-project-caught-in-aboriginalpolitics-says-developer (accessed April 2018).

Smith, Eric. An urban epicentre of decolonization in Canada: the Indigenous-settler alliance to make a place for peace at Asinabka. Thesis, Ottawa: Carleton University Political Economy Master of Arts Faculty of Graduate and Postdoctoral , 2011.

Switzer, Maurice. Switzer: Zibi Project will show whether indigenous people have a real say in development. June 6, 2016. http://ottawacitizen.com/opinion/columnists/switzer-zibi-projectwill-show-whether-indigenous-people-have-a-real-say-in-development (accessed April 2018).

TechnologyWater. Types of Soil Remediation Techniques and Methods. December 9, 2014. http://www.technologywater.com/post/104761516702/types-of-soil-remediation-techniquesand-methods (accessed April 2018). 
The Japan Times. These may not be the photographs that you are looking for. January 19, 2016. https://www.japantimes.co.jp/culture/2016/01/19/arts/may-not-photographslooking/\#.Wsjx1C7wbDc (accessed April 2018).

Thumbadoo, Romola V. Asinabka Sacred Chaudiere Site: Canada's Singualr Cultural Heritage Site. November 21, 2015. http://www.asinabka.com/Archives/2015-1121\%20Asinabka\%20Sacred\%20Chaudiere\%20Site\%20Cultural\%20Heritage\%20Note\%20updated .pdf (accessed April 2018).

UC Riverside. Seven Dimensions of Wellness. July 7, 2014. https://wellness.ucr.edu/seven_dimensions.html (accessed April 2018).

United Nations. United Nations Declaration on the Rights of Indigenous Peoples. Declaration, unknown: United Nations, 2008.

Urbsite. The Dawn of Hertiage (Part 1). August 2012. http://urbsite.blogspot.ca/2015/08/the-dawn-ofheritage-part-1.html (accessed March 2018).

WA Contents. 'Aesthetic Activism' (Really?). October 3, 2016. https://worldarchitecture.org/architecture-news/cgczg/_aesthetic_activism_really_html (accessed March 2018).

Walter Phillips Gallery Editions. Transference Tradition Technology. Alberta: Walter Phillips Gallery, 2005.

The Story of the Coast Salish Knitters. Directed by Christine Welsh. 2000.

Windmill. "Domtar Lands Redevelopment." Zibi. Ottawa: Windmill Development Group Ltd., March 03, 2015.

-. Zibi Frequently Asked Questions. February 23, 2015. http://www.windmilldevelopments.com/2015/02/the-domtar-redevelopment-frequentlyasked-questions/ (accessed March 2018).

Yale University. Closing Remarks "Aesthetic Activism" by David Ruy. November 18, 2016. https://www.youtube.com/watch?v=xZdh8z9szV8 (accessed April 2018). 